\title{
ANÁLISE DA EFICIÊNCIA DA VÁRZEA DO RIBEIRÃO PARELHEIROS NA MELHORIA DE QUALIDADE DAS ÁGUAS QUE AFLUEM À REPRESA DO GUARAPIRANGA, SÃO PAULO
}

ALMIR APARECIDO DE SOUZA ANDRADE

Dissertação apresentada à Escola de Engenharia de São Carlos, da Universidade de São Paulo, como parte dos requisitos necessários a obtenção do Título de Mestre em Ciências da Engenharia Ambiental.

ORIENTADORA:

PROF $^{\mathrm{a}}$ DR $^{\mathrm{a}}$ ENEIDA SALATI

São Carlos - SP

2005 
Conhece-te a ti mesmo, conhece teu inimigo.

Tua vitória jamais correrá risco.

Conhece o lugar, conhece o tempo.

Então, tua vitória será total.

(Sun Tzu) 


\section{DEDICATÓRIA}

Aos meus filhos Lívia e Olavo, minha razão para continuar crescendo.

A minha esposa Cleide pela compreensão e amor sempre demonstrado.

Aos meus pais Roberto e Neiva pela criação responsável, educada e amorosa.

A Deus que sempre me ilumina e me guia. 


\section{AGRADECIMENTOS}

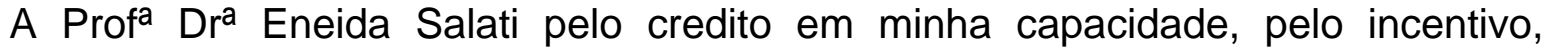
dedicação e orientação que foram primordiais para a conclusão deste trabalho. A amizade e confiança tiveram muita importância em toda condução do curso.

Ao amigo Prof. Dr. Frederico Lage Filho pela colaboração e pelo grande incentivo nos momentos mais difíceis da realização deste trabalho. Desde as conversas informais as orientações técnicas foram e serão de muita valia.

Ao Prof. Dr. Evaldo L. G. Espíndola pela compreensão e sugestões de conduta técnica e pedagógica, pessoalmente muito importantes para a realização deste estudo.

A Ana Lúcia Silva, amiga dedicada e prestativa.

A Ademir Tavares de Almeida, amigo, incentivador e facilitador.

A Sabesp pela disponibilização dos dados de controles qualitativos e quantitativos utilizados neste estudo.

Ao corpo gerencial da Sabesp pelo crédito a mim conferido quando de minha liberação para a realização deste curso.

Aos colegas e amigos da Sabesp que me ajudaram e demonstraram interesse por este trabalho.

Ao Prof. Dr. Sidney Ferreira Seckler Filho pela confiança e incentivo dedicados ao meu ingresso pós-acadêmico. 
A Profa ${ }^{\text {Dra }}{ }^{\mathrm{D}}$ Dione Mari Morita que sempre me expressou palavras de estimulo e estima.

Aos colegas de expediente administrativo do CRHEA - EESC.

A todos amigos conquistados durante o curso. 


\section{RESUMO}

Andrade, A.S.A.(2005). Análise da eficiência da várzea do ribeirão parelheiros na melhoria de qualidade das águas que afluem à represa do Guarapiranga, São Paulo. Dissertação (Mestrado) - Escola de Engenharia de São Carlos, Universidade de São Paulo, São Carlos, 2005.

A Várzea do Ribeirão Parelheiros foi o objeto desse estudo. É um corpo de água que recebe água de transposição da Represa Billings para a Represa do Guarapiranga. Além disso, essa várzea recebe contribuições de poluentes de diversas fontes difusas originadas dentro e fora da Bacia do Guarapiranga, que deságuam no referido Ribeirão. Esse trabalho de pesquisa aplicada visou analisar a atuação da Várzea do Ribeirão Parelheiros na melhoria da qualidade das águas que afluem à represa do Guarapiranga. Foram analisados dados de qualidade de águas relativos a diversos parâmetros relevantes (médias mensais de contagens de coliformes totais e fecais, contagens de células de cianofíceas totais, concentrações de exotoxina, teores de nitrogênio total e fósforo total, cor aparente, turbidez, demanda química de oxigênio e $\mathrm{pH}$ ) e de vazões afluentes (mínimas, médias e máximas mensais) que tinham sido coletados durante cerca de dez meses seqüenciais, sendo quatro meses ditos "secos" e seis meses ditos "chuvosos". Não foi possível analisar completamente os efeitos do regime de vazões de entrada e saída da Várzea sobre a atuação desta como amortecedora de constituintes poluidores (por exemplo, de nutrientes - nitrogênio e fósforo) porque não se dispunha de dados das contribuições das fontes difusas, as quais não são monitoradas. A Várzea mostrou eficiência de remoção superior a 30\% em relação à melhoria de algumas, não de todas as variáveis ambientais, a saber turbidez, cianofíceas totais e microcistina, sendo que o regime pluviométrico exerceu influência significativa na atuação da Várzea como amortecedora de constituintes poluidores. Porém, as eficiências relativas aos períodos seco e chuvoso mostraram resultados muito semelhantes.

Palavras-chave: água (qualidade), áreas alagadas (várzea), Guarapiranga, macrófitas aquáticas, wetlands. 


\section{ABSTRACT}

Andrade, A.S.A.(2005). Analysis of the performance of the wetlands of the Parelheiros creek in the improvement of the quality of the waters before they enter the Guarapiranga reservoir, São Paulo. M. Sc. Dissertation - Escola de Engenharia de São Carlos, Universidade de São Paulo, São Carlos, 2005.

The Wetlands formed by Parelheiros Creek were the focal point of this study. The Creek is a water body that receives waters imported from Billings Reservoir into Guarapiranga Reservoir. The referred Creek and associated Wetlands also receive waters with diffuse source pollutants from inside and outside of the Guarapiranga watershed. This applied research work aimed at analyzing the performance of the referred Wetlands in the improvement of the quality of the above-mentioned waters before they enter the Guarapiranga reservoir. Water quality data regarding several relevant parameters (monthly averages of total and fecal coliform counts, total cyanobacteria cell counts, exotoxin concentrations, total nitrogen and total phosphorus, apparent color, turbidity, chemical oxygen demand and $\mathrm{pH}$ ) as well as flow data (minimum, average and maximum influent flows) were analyzed. The data were collected during a ten-month period comprised of four dry weather months followed by six wet weather months. It was not possible to analyze completely the effects of flow regime on the performance of the Wetlands as a "buffer zone" for pollutant abatement because there was no available data on the diffuse source contributions, since they are not monitored. The Wetlands showed removal efficiencies above $30 \%$ with respect to the improvement of some (not all) variables, as follows: turbidity, total cyanobacteria concentration and microcystia concentration. The pluviometry exerted significant influence on the Wetland performance as a "buffer zone" for abatement of certain water constituents which represent pollution. However, removal efficiencies regarding wet and dry periods were very similar to each other.

Key words: Water (quality), Swampy, Guarapiranga, aquatic macrophites, wetlands. 


\section{LISTA DE FIGURAS}

Página

Figura 1. Mapa da Bacia Hidrográfica da represa Guarapiranga (fonte: SABESP, s/data). 1

Figura 2. Imagem de satélite da região metropolitana de São Paulo (fonte: anônima). 2

Figura 3. Imagem aérea da represa do Guarapiranga (fonte: Sabesp, s/data). ..... 3

Figura 4. Imagem aérea do Sistema de captação e bombeamento Taquacetuba (fonte: acervo do autor, 2003). 5

Figura 5. Sistema de dissipação de energia e canal de afluência à Várzea do Ribeirão Parelheiros (fonte: acervo do autor, 2003). 6

Figura 6. Várzea do Parelheiros (fonte: acervo do autor, 2003). ......................... 7

Figura 7. Vista da barragem da represa do Guarapiranga, instalações de captação, centro de bombeamento e canal de descarga (fonte: acervo do autor, 2000).

Figura 8. Ponto de afluência do rio Embu-Guaçu (principal afluente natural do Guarapiranga). A imagem retrata o estado da várzea em período de estiagem (Fonte: acervo do autor, 2000). 24

Figura 9. Ocupações irregulares na bacia Billings (fonte: Capobianco, 2002). 26 
Página

Figura 10. Florações de algas no braço Bororé da represa Billings (Capobianco, 2002). 27

Figura 11. Compartimentação do braço Rio Grande "captação de água a direita ao fundo" (Capobianco, 2002)....... 27

Figura 12. Várzea do ribeirão Parelheiros, imagem de caracterização da área de estudo (Fonte: acervo do autor, 2000). 29

Figura 13. Várzea do ribeirão Parelheiros verificando-se, ao fundo, a represa do Guarapiranga (Fonte: acervo do autor, 2000). 30

Figura 14. Vista do canal de recepção de água da Billings (fonte: acervo do autor, 2003). 31

Figura 15. Invasão da várzea para uso agrícola (fonte: acervo do autor, 2000). 32

Figura 16. Núcleo habitacional e campo de futebol invadindo a várzea (fonte: acervo do autor, 2000). 32

Figura 17. Esquema ilustrativo do sistema integrado Guarapiranga/Billings (fonte: SABESP, s/data). 35

Figura 18. Valores máximos, mínimos, médios, acumulados da variável pluviometria da bacia, referentes aos períodos de junho a setembro/03 (meses secos) e de outubro/03 a março/04 (meses chuvosos). 40

Figura 19. Valores acumulados mensais e média por período da variável pluviometria da bacia, referentes aos períodos de junho a setembro/03 (meses secos) e de outubro/03 a março/04 (meses chuvosos). .40 
Página

Figura 20. Valores máximos, mínimos e médios da variável vazão de entrada da várzea, referentes aos períodos de junho a setembro/03 (meses secos) e de outubro/03 a março/04 (meses chuvosos). 42

Figura 21. Valores médios das variáveis vazão e precipitação, referentes aos períodos de junho a setembro/03 (meses secos) e de outubro/03 a março/04 (meses chuvosos). 42

Figura 22. Valores médios da variável fósforo total da entrada (GU213) e saída (GU107) da várzea, referentes aos períodos de junho a setembro/03 (meses secos) e de outubro/03 a março/04 (meses chuvosos). 44

Figura 23. Valores médios da variável nitrogênio total da entrada e saída da várzea, referentes aos períodos de junho a setembro/03 (meses secos) e de outubro/03 a março/04 (meses chuvosos). 46

Figura 24. Valores médios da variável DQO da entrada e saída da várzea, referentes aos períodos de junho a setembro/03 (meses secos) e de outubro/03 a março/04 (meses chuvosos). 48

Figura 25. Valores médios da variável cor da entrada e saída da várzea, referentes aos períodos de junho a setembro/03 (meses secos) e de outubro/03 a março/04 (meses chuvosos) .50

Figura 26. Valores médios da variável cor da entrada e saída da várzea, referentes aos períodos de junho a setembro/03 (meses secos) e de outubro/03 a março/04 (meses chuvosos). .52

Figura 27. Valores médios da variável turbidez da entrada e saída da várzea, referentes aos períodos de junho a setembro/03 (meses secos) e de outubro/03 a março/04 (meses chuvosos). .54

Figura 28. Valores médios da variável coliformes totais da entrada e saída da várzea, referentes aos períodos de junho a setembro/03 (meses secos) e de outubro/03 a março/04 (meses chuvosos). .56

Figura 29. Valores médios da variável coliformes fecais da entrada e saída da várzea, referentes aos períodos de junho a setembro/03 (meses secos) e de outubro/03 a março/04 (meses chuvosos). 58 
Página

Figura 30. Valores médios da variável algas cianofíceas da entrada e saída da várzea, referentes aos períodos de junho a setembro/03 (meses secos) e de outubro/03 a março/04 (meses chuvosos) .......................................................60

Figura 31. Valores médios da variável microcistina da entrada e saída da várzea, referentes aos períodos de junho a setembro/03 (meses secos) e de outubro/03 a março/04 (meses chuvosos)...........................................................................62 


\section{LISTA DE TABELAS}

Página

Tabela 1. Carga gerada de Fósforo Total na bacia do Guarapiranga, por tipo de fonte (fonte: SMA/PRIME ENGENHARIA, 1998). .......................................... 3

Tabela 2 - Relação entre o estado trófico de um lago e as concentrações de fósforo total (fonte: Agudo, 1990). ............................................................. 13

Tabela 3. Valores médios das variáveis obtidos na entrada (GU213) e Saída (GU107) da várzea do Parelheiros, incluindo-se vazão e precipitação, nos

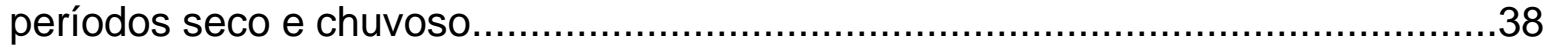

Tabela 4. Valores máximos, mínimos, médios, acumulados e desvios padrão da variável pluviometria da bacia

Tabela 5. Valores máximos, mínimos, médios e desvios padrão das vazões da entrada da várzea.....

Tabela 6. Valores máximos, mínimos, médios e desvios padrão da variável fósforo total da entrada e saída da várzea.

Tabela 7. Valores máximos, mínimos, médios e desvios padrão da variável nitrogênio total da entrada e saída da várzea.

Tabela 8. Valores máximos, mínimos, médios e desvios padrão da variável DQO da entrada e saída da várzea.

Tabela 9. Valores máximos, mínimos, médios e desvios padrão da variável cor da entrada e saída da várzea. 49

Tabela 10. Valores máximos, mínimos, médios e desvios padrão da variável pH da entrada e saída da várzea.

Tabela 11. Valores máximos, mínimos, médios e desvios padrão da variável turbidez da entrada e saída da várzea. 
Página

Tabela 12. Valores máximos, mínimos, médios e desvios padrão da variável coliformes totais da entrada e saída da várzea......................................................55

Tabela 13. Valores máximos, mínimos, médios e desvios padrão da variável coliformes fecais da entrada e saída da várzea................................................57

Tabela 14. Valores máximos, mínimos, médios e desvios padrão da variável algas cianofíceas da entrada e saída da várzea.

59

Tabela 15. Valores máximos, mínimos, médios e desvios padrão da variável microcistina da entrada e saída da várzea...........................................................61 


\section{ㄴISTA DE ANEXOS}

Página

ANEXO 1. SISTEMA PRODUTOR TAQUACETUBA/GUARAPIRANGA PLANO DE CONTINGÊNCIA - CIANOBACTÉRIAS (Revisado em Maio/2002, texto extraído

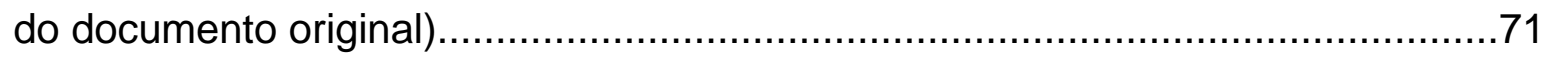

ANEXO 2. Dados de monitoramento de qualidade de água do ponto GU 213 -

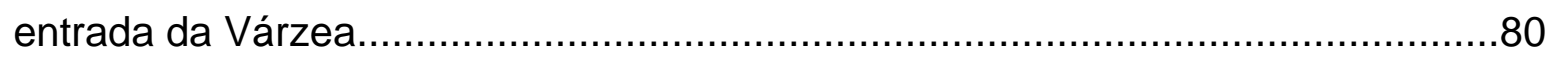

ANEXO 3. Dados de monitoramento de qualidade de água do ponto GU 107 saída da Várzea. .83

ANEXO 4. Dados diários de controle de precipitação.........................................86

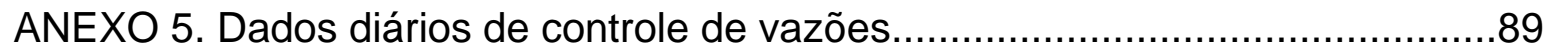




\section{INTRODUÇÃO}

A Bacia Hidrográfica da represa Guarapiranga ocupa vasta extensão com área aproximada de 630 km², situando-se em território dos municípios de São Paulo, Itapecerica da Serra, Embu, Embu Guaçu, Cotia, São Lourenço e Juquitiba (Figura 1).

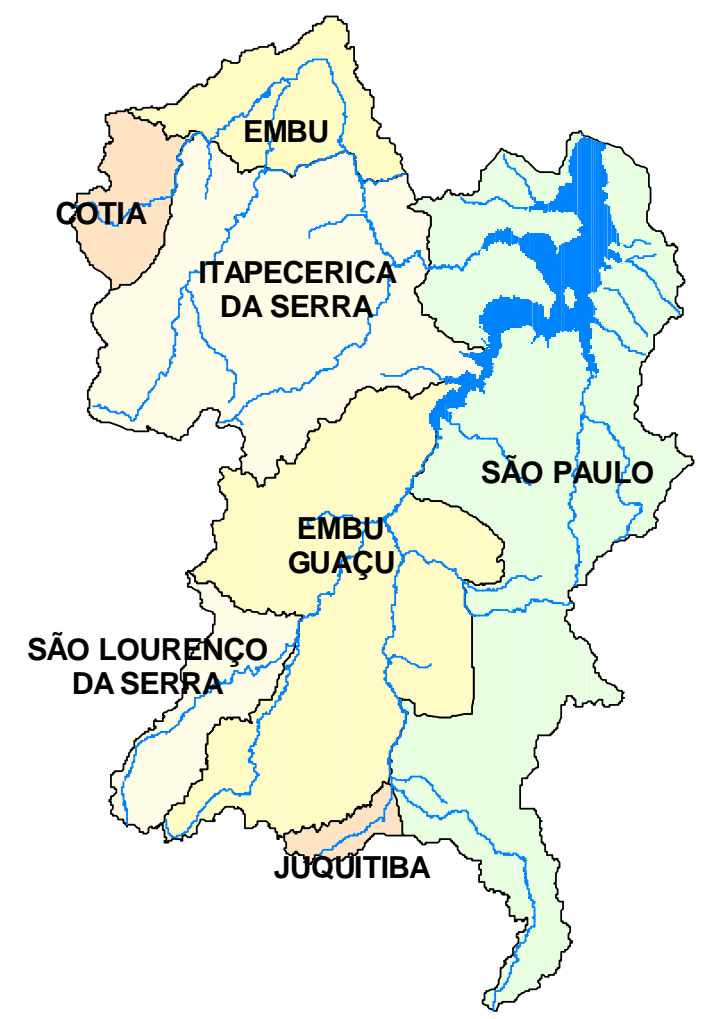

Figura 1. Mapa da Bacia Hidrográfica da represa Guarapiranga (Fonte: SABESP, s/data).

Construída entre os anos de 1906 e 1908 e utilizada originalmente para a geração de energia elétrica, em 1927 passou a ser utilizada como fonte de abastecimento público, sendo responsável pelo abastecimento de 18,8 \% da Região Metropolitana de São Paulo.

Atualmente existe uma preocupação com relação à deterioração progressiva da qualidade das águas dessa represa devido à expansão da 
ocupação do solo na região (Figura 2), ocasionando um crescente comprometimento da qualidade da água devido ao aumento significativo do aporte de nutrientes (principalmente nitrogênio e fósforo), além de coliformes totais, através dos tributários ou difusamente ao longo da região limítrofe da represa.

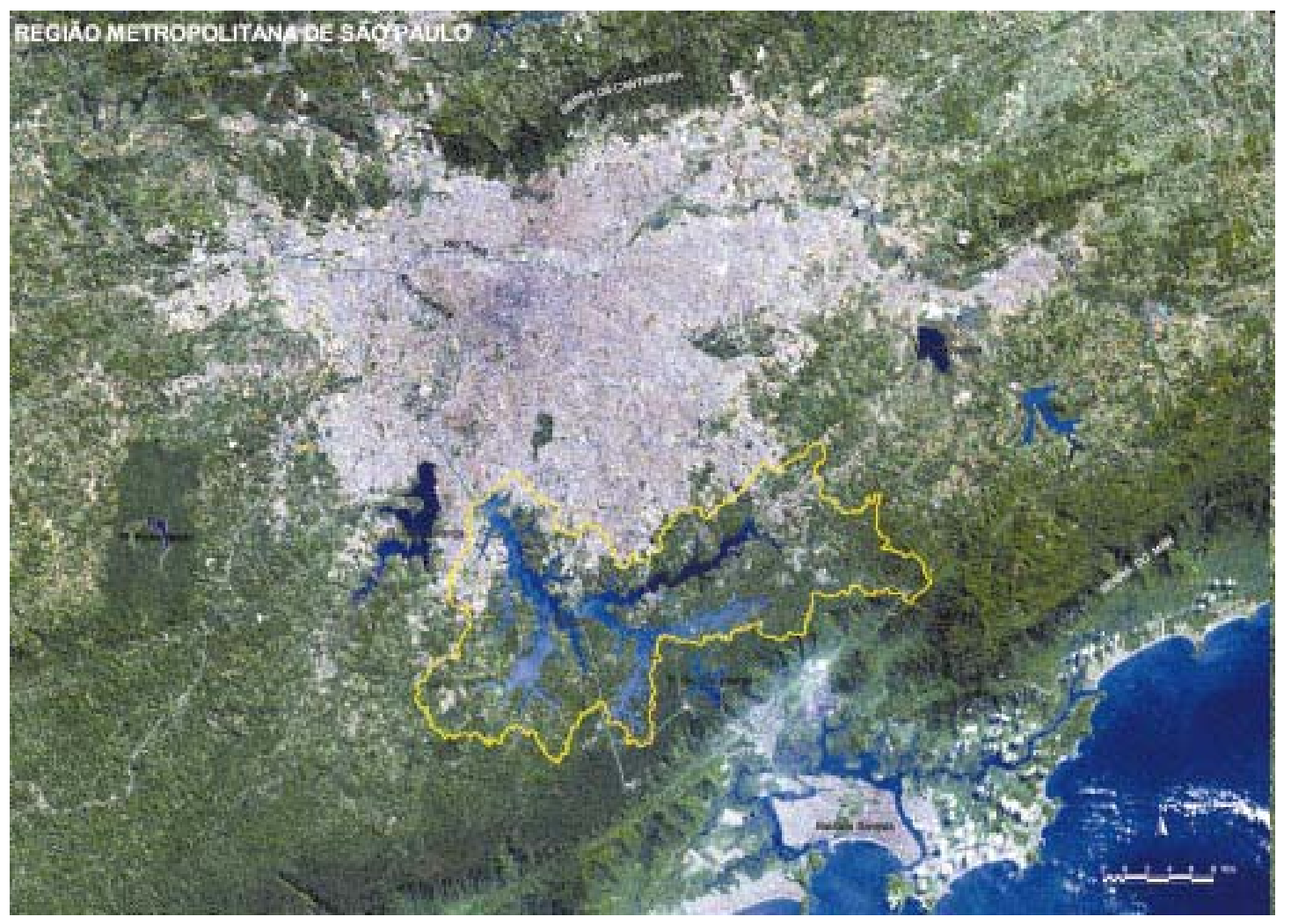

Figura 2. Imagem de satélite da região metropolitana de São Paulo (Fonte: anônima).

De acordo com o relatório "Avaliação da Poluição por Fontes Difusas Afluente a Represa Guarapiranga" (SMA/Prime Engenharia, 1998) a carga de fósforo total gerada na bacia é principalmente devido ao despejo de esgoto doméstico (Tabela 1) (SMA/JPE-EPAL-TAHAL, 2000). 
Tabela 1. Carga gerada de Fósforo Total na bacia do Guarapiranga, por tipo de fonte (fonte: SMA/PRIME ENGENHARIA, 1998).

\begin{tabular}{|l|c|c|c|}
\hline \multicolumn{1}{|c|}{ Tipo de Fonte } & Período Seco & $\begin{array}{c}\text { Período } \\
\text { Chuvoso }\end{array}$ & Média Anual \\
\hline Esgoto Doméstico & $96 \%$ & $42 \%$ & $62 \%$ \\
\hline Carga Difusa Urbana & $3 \%$ & $40 \%$ & $27 \%$ \\
\hline Carga Difusa Rural & $1 \%$ & $18 \%$ & $11 \%$ \\
\hline
\end{tabular}

Apesar da maior carga de fósforo afluente a represa ser devida ao esgoto doméstico, as cargas difusas (rural e urbana) contribuem no período chuvoso com $58 \%$ e na média anual com $38 \%$ da carga total.

É importante salientar que, no caso da bacia hidrográfica do Guarapiranga, devido à sua ocupação desordenada (Figura 3) e sem infraestrutura, o esgoto doméstico pode também ser considerado como carga difusa. Este vem sendo lançado na superfície da bacia, fazendo com que esta carga poluidora aflua à represa como carga difusa, principalmente nos eventos de chuva.

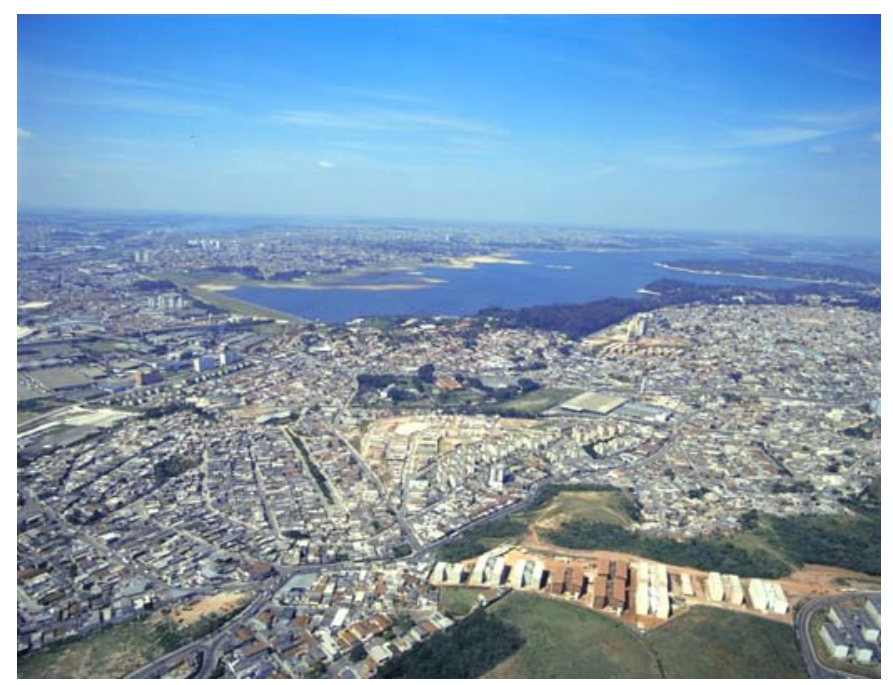

Figura 3. Imagem aérea da represa do Guarapiranga (Fonte: Sabesp, s/data). 
Desta forma, além da redução da carga externa devido à carga pontual, há também necessidade do abatimento de nutrientes devido a outros componentes da carga difusa afluente a represa. A menos que estas cargas externas sejam reduzidas, qualquer tratamento na represa para reduzir nutrientes em longo prazo não trará benefícios quanto à qualidade de suas águas (SMA/JPE-EPAL-TAHAL, 2000).

Outro fator de relevante importância na modificação da qualidade da água é que a partir de agosto de 2000 iniciou-se a transferência de água da represa Billings, captada no braço Taquacetuba, para a represa do Guarapiranga, objetivando-se incrementar a captação de água para tratamento em $2 \mathrm{~m} 3 / \mathrm{s}$.

A represa Billings foi construída em 1927 para possibilitar a geração de energia elétrica em Cubatão na Baixada Santista, por meio da utilização da usina de Henry Borden. A partir da década de 50 passou a receber água oriunda dos rios Tamanduateí, Tietê e Pinheiros, já naquela época contaminados com efluentes sanitários e industriais (Sendacz et al., 1999). Durante a década de 70 a represa Billings já apresentava sinais de alto grau de poluição de suas águas juntamente com a ocorrência de florações de algas.

No início dos anos 90 foi proibida a transferência de água daqueles rios para a represa, a não ser pela necessidade da contingência de inundações na cidade de São Paulo. Ainda nestes anos começou a cogitarse a utilização das águas deste manancial como contribuição ao aumento da capacidade de regulação hídrica da represa do Guarapiranga. Esta idéia, quando relacionada à questão de qualidade das águas do reservatório Guarapiranga gerou grande polêmica uma vez que se temia a contaminação do sistema pelas águas da represa Billings, já poluída por efluentes principalmente de origem industrial. 
O Sistema de Captação e Bombeamento Taquacetuba é composto por uma elevatória flutuante e uma elevatória em terra (Figura 4), com 13,9 $\mathrm{km}$ de adutora, sendo $8,3 \mathrm{~km}$ de transferência por gravidade com $80 \mathrm{~m}$ de diferença de cota, sistema de dissipação de energia e canal de afluência à várzea do ribeirão Parelheiros (Figura 5).

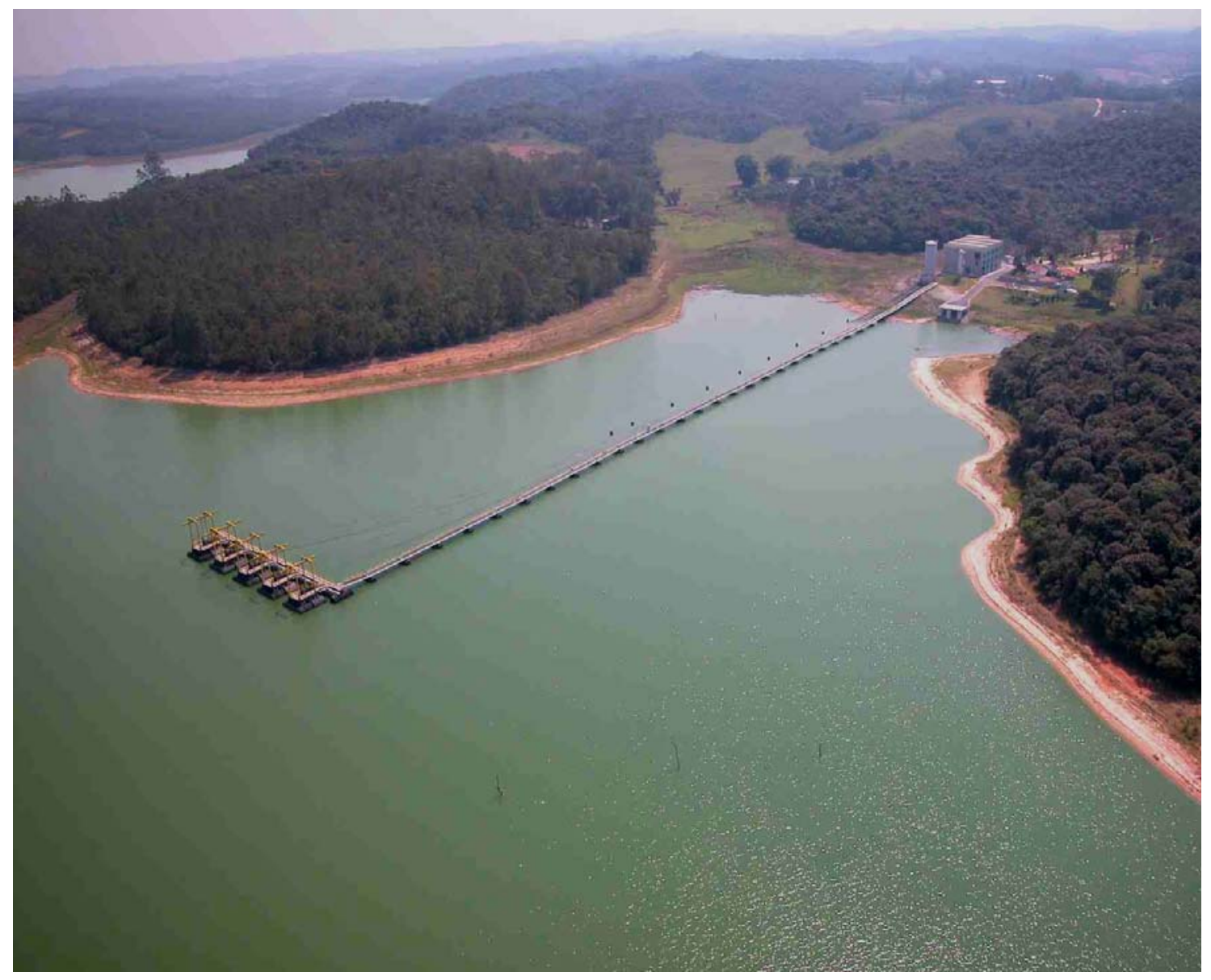

Figura 4. Imagem aérea do sistema de captação e bombeamento Taquacetuba (Fonte: acervo do autor, 2003). 


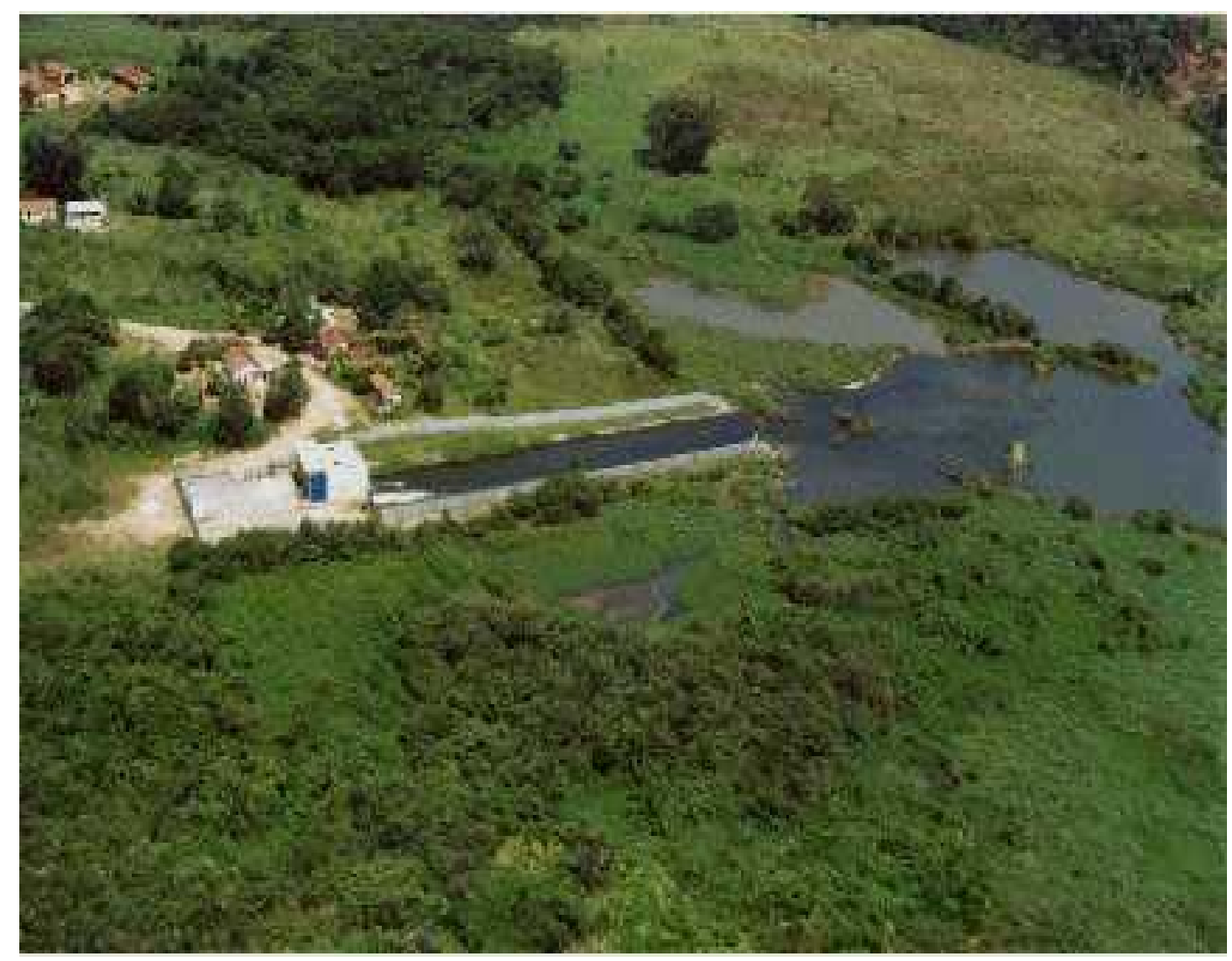

Figura 5. Sistema de dissipação de energia e canal de afluência à várzea do ribeirão Parelheiros (Fonte: acervo do autor, 2003).

O ribeirão Parelheiros aflui na represa do Guarapiranga onde forma uma várzea de aproximadamente 93 hectares com grande influência antrópica (Figura 6). O potencial depurador desta várzea quanto à redução de nutrientes, carga orgânica, algas cianofíceas e de toxinas provenientes de seu metabolismo será objeto de análise deste estudo a partir da avaliação dos resultados analíticos das variáveis físicas, químicas e biológicas, oriundos do monitoramento realizado pela Companhia de Saneamento Básico do Estado de São Paulo - Sabesp, correspondentes a um período de 10 meses compreendidos aos períodos seco e chuvoso. 


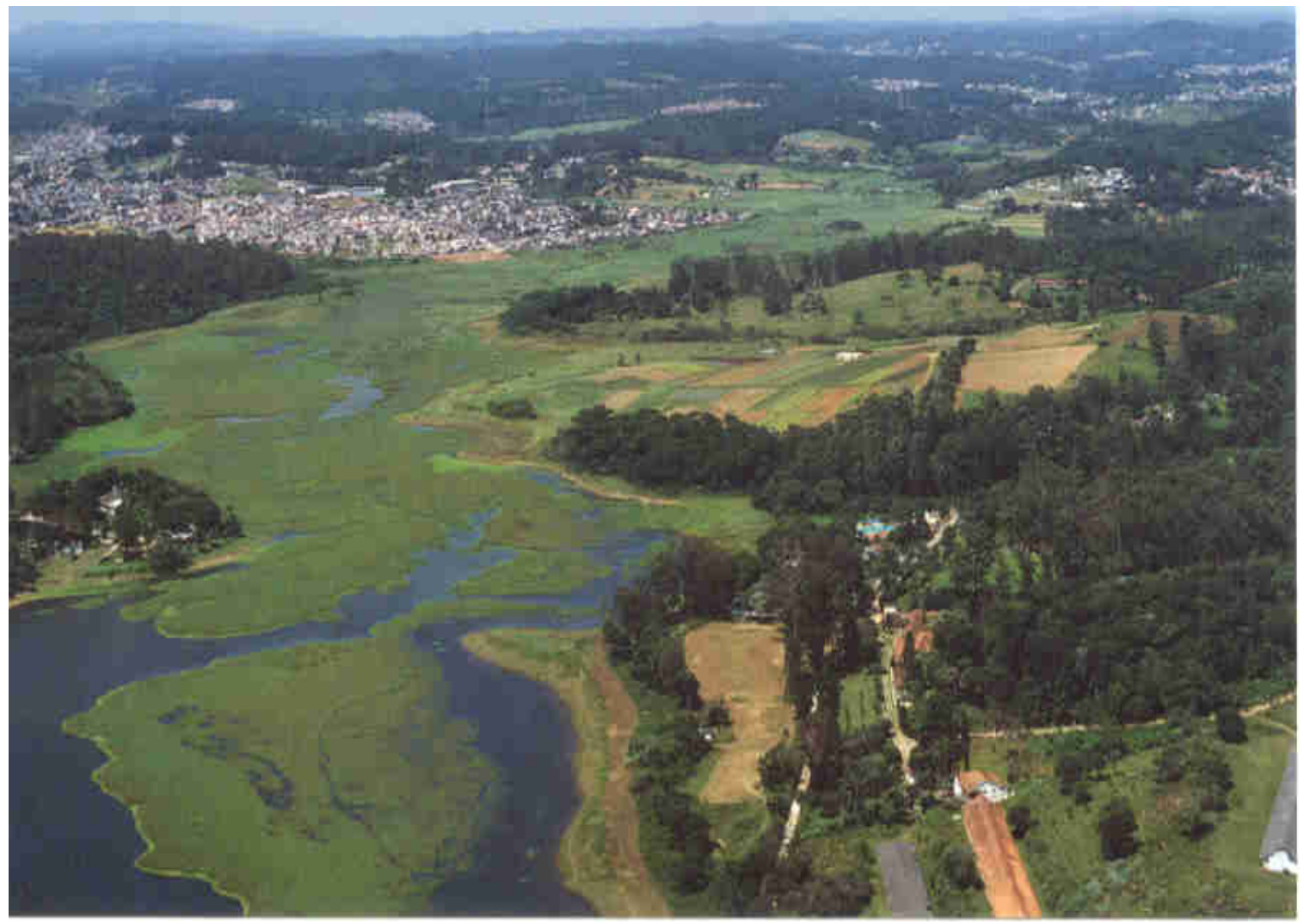

Figura 6. Várzea do Parelheiros (Fonte: acervo do autor, 2003). 


\section{OBJETIVO}

Os objetivos desta pesquisa foram:

a) Avaliar o papel desempenhado pela Várzea na melhoria da qualidade da água que aflui à represa do Guarapiranga, por meio de análise dos resultados das variáveis físicas, químicas e biológicas provenientes dos dados de qualidade da água a montante e a jusante da mesma.

b) Comparar a eficiência da várzea em períodos distintos do ano, seco e chuvoso, no período de junho de 2003 a março de 2004.

c) Reconhecer os fatores potenciais que podem influenciar 0 comportamento da área alagada em relação à sua maior ou menor eficiência. 


\section{REVISÃO BIBLIOGRÁFICA}

\section{1 ÁREAS ALAGADAS}

As áreas alagadas ou várzeas, comumente tratadas, usando-se o termo do idioma em inglês "Wetland", podem ser naturais, induzidas ou construídas. As várzeas naturais têm importantes funções dentro dos ecossistemas onde estão inseridos, entre as quais se destacam: a capacidade de regularização dos fluxos de água, amortecendo os picos de enchentes; a capacidade de modificar e controlar a qualidade das águas; sua importância na função de reprodução e alimentação da fauna aquática, incluindo os peixes; a proteção à biodiversidade como área de refúgio da fauna terrestre e controle da erosão, evitando o assoreamento dos rios (Salati, 2000).

Cowardin et al. (1979) define de forma muito abrangente as áreas alagadas como sendo áreas de transição entre sistemas aquáticos e terrestres, onde o nível das águas subterrâneas pode ser superficial, próximo a superfície do solo ou coberta por uma pequena lâmina d'água.

As principais propriedades que tornam estas áreas importantes para o controle de poluentes e contaminantes em corpos d'água são: alta produtividade de vegetação; grande capacidade de absorção dos sedimentos; altas taxas de oxidação pela microflora associada à biomassa das plantas e grande capacidade de reter nutrientes, poluentes e contaminantes (Salati, 2000).

"Plantas aquáticas vasculares como os aguapés (Eichhornia crassipes), são promessas de solução para muitos problemas da comunidade, tais como: despoluição das águas, aumento de fonte alimentar, energética e fertilizante. Essas plantas quando utilizadas em sistemas de purificação, seguindo um adequado programa de manejo para colheita, pode 
representar um eficiente e barato sistema de tratamento de água, removendo 90\% de DBO5 e 80\% de totais de sólidos suspensos" (Roquette Pinto (1987) apud Elias (2003)).

Por outro lado, macrófitas aquáticas como os aguapés (Eichhornia crassipes), as alfaces d'água (Pistia stratiotes) e outras, formam grandes emaranhados de plantas que podem cobrir grandes áreas e se deslocar ao sabor dos ventos e correntes dos reservatórios. Os bancos de macrófitas impedem que plantas submersas e o fitoplâncton recebam luz solar, o que leva ao prejuízo o seu desenvolvimento. Também produzem grande quantidade de matéria orgânica que podem causar regimes anóxicos e em conseqüência a resolubilização de material sedimentado e ainda a formação e liberação de gás sulfídrico. O material derivado destas plantas não tem importância nutricional na dieta do zooplâncton e peixes. A infestação de macrófitas pode ser inconveniente e prejudicial à comunidade, uma vez que pode restringir o acesso recreacional, a pesca, bem como aos processos de irrigação e geração de energia elétrica (UNEP, 2001).

Os processos físicos, químicos e biológicos, isto é, o ciclo biogeoquímico que ocorre nesses ecossistemas e que são responsáveis pela alteração da qualidade das águas, varia grandemente de acordo com o regime hidrológico, geologia, fatores climáticos e bióticos. As Wetlands construídas diferem das naturais por proporcionarem o controle do regime hidrológico e ainda pela possibilidade de composição do substrato utilizado, uma vez que este pode ser projetado para otimização do sistema (Salati, 2000).

Wetzel (1993) menciona que "as Wetlands construídas tem despertado interesse mundial devido em parte ao movimento preservacionista de Wetlands naturais, tendo em vista que o seu uso indevido provocou profundas alterações, descaracterizando estas áreas". 
A utilização de Wetlands construídas como sistemas de tratamento de águas residuais têm se intensificado nestas últimas décadas. Estes sistemas têm sido matéria de muitas discussões, as quais apresentam um ponto positivo: o desenvolvimento de pesquisas e experimentos conduzindo para um maior conhecimento e experiências nessa linha de pesquisa (Harbel, 1997).

Segundo Salati (2000) a remoção de nutrientes e contaminantes provenientes de efluentes domésticos e industriais são relatados em estudos e experiências de utilização de várzeas naturais e construídas, porém os resultados são muito variáveis. Observa-se que essa variação é decorrente da especiação química presente nos efluentes assim como a carga dos mesmos associados à várzea.

No caso particular da transposição de água entre represas, que pode ser feito através de instalações hidráulicas para este fim ou por rios de interligação, é desejável que antes da afluência a represa de recepção, as várzeas proporcionem papel significativo quanto à minimização da concentração de nutrientes e de florações de algas, notoriamente cianofíceas, assim como de substâncias, provenientes de seu metabolismo, tendo assim papel importante e estratégico na melhoria da água a ser captada para abastecimento público.

Dado o importante papel das várzeas no processo de depuração das águas devida a retenção e o reprocessamento de nutrientes, poluentes e contaminantes, e ainda de sua capacidade reguladora de fluxos hídricos, as áreas alagadas exercem grande importância como sistema natural de melhoria da qualidade de águas. 


\subsection{NUTRIENTES (NITROGÊNIO E FÓSFORO)}

Nutrientes (nitrogênio e fósforo em suas diversas formas) podem ser encontrados com abundância na natureza. Em águas sejam elas de fontes naturais ou efluentes, são variáveis de extrema importância como indicadores de qualidade do manancial e do processo. Segundo Kadlec (1996) o nitrogênio atmosférico também inclui formas de nitrogênio dissolvidas associados à micro gotas, voltando para o solo juntamente com as chuvas.

Em represas de águas naturais o excesso de nutrientes interfere em diversos aspectos, sejam eles proliferação de algas, toxidade para algumas comunidades aquáticas ou aumento do consumo de cloro no processo de potabilização de água. Quando presentes em baixas concentrações, podem atuar como fator limitante na produção primária de ecossistemas aquáticos (Esteves, 1998).

As fontes de nutrientes podem ser naturais (ar, difusão biológica planctônica) ou oriundas de atividades antrópicas (cargas difusas oriundas de drenagem urbana, fertilização agrícola, efluentes sanitários e industriais).

O nitrogênio obedece a um ciclo onde os animais e plantas incorporam em seus tecidos o nitrogênio orgânico através de seu metabolismo alimentar. A morte destes gera matéria orgânica e a decomposição desta forma o nitrogênio amoniacal $\left(\mathrm{NH}_{3}\right.$ ou $\left.\mathrm{NH}_{4}{ }^{+}\right)$.

Nas águas, a nitrificação (processo de oxidação biológica em meio aeróbio) converte o nitrogênio amoniacal em nitrito (ação das bactérias Nitrosomonas) e posteriormente em nitrato (ação das Nitrobacter). A nitrificação é o principal mecanismo de transformação, o qual reduz a concentração de amônia em muitos sistemas de áreas alagadas, reduzindo o nitrogênio amoniacal a nitrato (Kadlec, 1996). 
Em sedimentos de lagos ou rios, unidades de separação de sólidos, onde ocorrem condições de anaerobiose, ocorre o processo inverso, que consiste na redução biológica do nitrato a nitrito, e posteriormente do nitrito a nitrogênio gasoso, processo este chamado de desnitrificação.

Ocorrem ainda, no ciclo do nitrogênio na natureza, as fixações química e biológica e o seu uso como nutriente, sendo que as plantas são capazes de metabolizar nitratos e os animais nutrem-se, principalmente, de nitrogênio na forma orgânica.

O fósforo tem como origem águas residuárias, detergentes, fertilizantes e rochas fosfáticas. Não possui fase gasosa e não sofre transformações pela ação de microorganismos. Em ambientes aquáticos, pode ser um fator limitante para a produção primária (Lamparelli, 2003).

As águas drenadas em áreas agrícolas também podem ocasionar a presença excessiva de fósforo em águas naturais, o que leva a condução de processos de eutrofização das águas naturais. Quando se atinge nível hiper eutrófico (Tabela 2), além das algas, aparecem plantas aquáticas superiores (macrófitas), prejudicando os usos múltiplos daquela água (Piveli, 1996).

Tabela 2 - Relação entre o estado trófico de um lago e as concentrações de fósforo total (fonte: Agudo, 1990).

\begin{tabular}{|cc|}
\hline Nível & $\mathrm{P}_{\mathrm{T}}(\mathrm{mg} / \mathrm{L})$ \\
\hline Oligotrófico & $<0,010$ \\
Mesotrófico & $0,010-0,035$ \\
Eutrófico & $0,035-0,100$ \\
Hipereutrófico & $>0,100$ \\
\hline
\end{tabular}


Do ponto de vista limnológico, todas as formas de fosfato são importantes, no entanto, o ortofosfato é a principal forma de fosfato assimilada pelos vegetais aquáticos (Esteves, 1988). De acordo com Elias (2003) "em águas tropicais, devido à alta temperatura, o metabolismo dos organismos aumenta consideravelmente, fazendo com que o ortofosfato seja mais rapidamente assimilado e incorporado na sua biomassa. O fósforo é um importante nutriente requerido pelas plantas e é freqüentemente um fator limitante para a produtividade do ecossistema aquático", portanto, é um importante variável de classificação das águas naturais, participando também na composição de índices de qualidade de águas.

\subsection{DEMANDA QUÍMICA DE OXIGÊNIO - DQO}

O oxigênio dissolvido é o elemento vital no metabolismo dos microrganismos aeróbios que habitam as águas naturais ou os reatores do tratamento biológico de esgotos. Nas águas naturais, o oxigênio é indispensável também para outros seres vivos, especialmente os peixes, sendo que a maioria das espécies não resiste a concentrações de oxigênio dissolvido na água inferiores a 4,0 mg/L, representando, portanto, um variável de extrema significância na classificação das águas naturais (Piveli, 1996).

O mesmo autor explica que "a demanda química de oxigênio consiste em uma técnica utilizada para a avaliação do potencial de matéria redutora de uma amostra, através de um processo de oxidação química, em que se emprega o dicromato de potássio $\left(\mathrm{K}_{2} \mathrm{Cr}_{2} \mathrm{O}_{7}\right)$. Neste processo, $\mathrm{o}$ carbono orgânico de um carboidrato, por exemplo, é convertido em gás carbônico e água".

Desta forma a medida do dicromato de potássio consumido pela reação de oxidação de matéria orgânica, resulta a demanda química de oxigênio. A relação entre demanda química de oxigênio e a demanda 
bioquímica de oxigênio é geralmente maior para $\mathrm{DQO}$ pois o oxidante químico utilizado para análise reage com um amplo grupo de compostos (Elias, 2003).

A presença de um alto teor de matéria orgânica pode induzir à completa extinção do oxigênio na água, provocando a morte de vários organismos aquáticos.

\subsection{COR E TURBIDEZ}

A cor da água é conferida através da presença no meio aquoso de pigmentos em solução ou dispersão coloidal. Já a turbidez é dada pela presença de material particulado em suspensão (silte, areia, detritos orgânicos e inorgânicos, etc.), capaz de dispersar luz através de reflexão.

A presença de cor e turbidez em água naturais é normal, porém o aumento destas pode afetar a vida característica de um dado manancial.

Na região pelágica existe a zona fótica, onde a luz penetra, e cujo limite superior é a superfície da água e o inferior varia de acordo com o grau de turbidez e cor da água. Dentro dessa zona a porção superior, onde ocorre fotossíntese, que vai até que a radiação atinja 1\% da inicial, denomina a zona eufótica (Pereira, 2003).

A dificuldade de penetração de luz pode diminuir as reações de fotossíntese, afetando o desenvolvimento do fitoplâncton e de outras plantas submersas. Já as partículas em suspensão, após sua sedimentação, podem provocar agravos nos organismos bentônicos por soterramento (Branco, 1986). 


\subsection{POTENCIAL HIDROGENIÔNICO - pH}

O potencial hidrogeniônico é definido como o logaritmo negativo da concentração de íons hidrogênio, e se define em uma faixa de 1 a 14 a acidez ou basicidade de uma substância.

Conforme Pereira et al. (2003) "o pH em ambientes aquáticos é dependente de inúmeras variáveis, mas na maioria das vezes a concentração de íons $\mathrm{H}^{+}$depende da dissociação de ácido carbônico $\left(\mathrm{H}_{2} \mathrm{CO}_{3} \leftrightarrow 2 \mathrm{H}^{+}+\mathrm{CO}_{3}{ }^{2-}\right)$ que gera baixos valores de $\mathrm{pH}$, e das reações de íons carbonato e bicarbonato com a molécula d'água que elevam o $\mathrm{pH}$ $\left(\mathrm{CO}_{3}{ }^{2-}+\mathrm{H}_{2} \mathrm{O} \leftrightarrow \mathrm{HCO}_{3}^{-}+\mathrm{OH}^{-} / \mathrm{HCO}_{3}^{-}+\mathrm{H}_{2} \mathrm{O} \leftrightarrow \mathrm{H}_{2} \mathrm{CO}_{3}+\mathrm{OH}^{-}\right)$. As comunidades aquáticas também interferem no valor de $\mathrm{pH}$. Com a fotossíntese, por exemplo, há um significante aumento do $\mathrm{pH}$ pela assimilação do $\mathrm{CO}_{2}$ do meio. Outros processos como os de oxidação biológica, por exemplo, contribuem para o abaixamento do $\mathrm{pH}$.

O gás carbônico apresenta comportamento inverso ao oxigênio e está diretamente ligado ao balanço de íons hidrogênio no meio e portanto do potencial hidrogeniônico. A água pura se dissocia fracamente em íons $\mathrm{H}+\mathrm{e}$ $\mathrm{OH}^{-}, \mathrm{o} \mathrm{pH}$ de águas naturais depende da interação entre os íons $\mathrm{H}+$ da dissociação do $\mathrm{H}_{2} \mathrm{CO}_{3}$ e dos íons $\mathrm{OH}^{-}$, resultantes da hidrólise de bicarbonato. A faixa de $\mathrm{pH}$ encontrada em águas naturais se estende entre 2 e 12, mas é em ambientes de água doce que se encontra uma maior variação da alcalinidade e acidez".

O desaparecimento de espécies no meio aquático pode decorrer de variações bruscas do pH (Elias, 2003). 


\subsection{COLIFORMES TOTAIS E COLIFORMES FECAIS}

De acordo dom Elias (2003), "uma enorme variedade de patógenos humanos é veiculada pelas águas contaminadas. Os patógenos podem ser funcionalmente divididos em cinco grupos: bactéria, vírus, fungos, protozoários e helmintos. A medição do índice de organismos em águas brutas e águas de tratamento torna-se uma atividade onerosa e tecnicamente desafiadora. Conseqüentemente, engenheiros ambientais e sanitaristas pesquisaram organismos indicadores facilmente monitorados e correlacionados com a população de organismos patogênicos Entretanto nenhum indicador perfeito foi encontrado, mas o grupo de bactérias coliformes tem sido utilizado durante muito tempo como a primeira escolha entre os organismos indicadores".

\subsection{CIANOBACTÉRIAS OU CIANOFÍCEAS}

Floração é a denominação do crescimento acelerado de organismos fitoplanctônicos, que podem trazer graves problemas econômicos e causar danos extremos à vida aquática em geral. Ocorrem mais comumente em lagos e represas cuja movimentação das águas é pequena, caracterizandose como ambientes lênticos.

É sabido que inúmeros microorganismos, notadamente certas algas, especialmente as cianofíceas (algas azuis), e os actinomicetos, são responsáveis pela produção de certos compostos orgânicos, resultantes do seu metabolismo, que, sob certas condições ainda não totalmente conhecidas, são liberados para a fase líquida. Além do aspecto estético deve ser ressaltado que as cianofíceas possuem enorme potencial para a produção de toxinas, despertando relevante preocupação sanitária. Todas estas substâncias provenientes do metabolismo algal são, indubitavelmente, muito difíceis de serem removidas (Andrade et al., 2000). 
As algas azuis em função de um de seus principais pigmentos, a ficocianina, juntamente com os demais pigmentos, confere à alga coloração azul-esverdeada. Neste grupo, os pigmentos encontram-se distribuídos em toda a massa protoplasmática de cada célula. Diferem dos demais grupos por não terem núcleo individualizado (procariontes). Não possuem amido, que é uma substância de reserva muito difundida no reino vegetal. Suas formas de reserva são gotas de óleo, que aparecem no citoplasma juntamente com grânulos de proteína, além de pseudovacúolos (espécies de bolhas de gás, que se acumulam principalmente em células mais velhas). Geralmente são envolvidas por uma massa gelatinosa ou revestidas por uma bainha mucilaginosa (Carvalho, 2003).

As formas das células são variadas, podendo ser unicelularesféricas, que são consideradas o tipo mais primitivo das cianofíceas, ou filamentosas, que podem formar grandes filamentos (tricomas), os quais apresentam células especializadas denominadas heterocistos, cuja função é a fixação biológica do nitrogênio atmosférico. É característica ainda a formação de esporos, denominados acinetos, células geralmente bem maiores que as demais, com membrana espessa devido à presença de maior concentração de substância de reserva (Branco, 1986).

As cianofíceas podem ser autotróficas (assimilando $\mathrm{CO}_{2}$, com ajuda de energia solar) ou mixotróficas (assimilando compostos orgânicos), o que possibilita sua existência nas partes mais profundas de lagos, na ausência de luz, como é o caso de algumas espécies de Oscillatoria.

O controle de cianofíceas em represas, principalmente as utilizadas para o abastecimento publico, deve ser alvo de controle, uma vez que estes microorganismos possuem significado sanitário que merece extrema atenção pois são produtores potenciais de substâncias que conferem gosto e odor e ainda toxinas ofensivas à saúde pública. 
Pesquisas efetuadas pela American Water Works Association (AWWA) mostraram que o primeiro critério utilizado pela população na aceitação da água distribuída à mesma era a capacidade desta apresentar ou não odor e gosto. Esta mesma pesquisa mostrou que a maioria dos consumidores norte-americanos que compram água mineral o faz pelo fato da água de abastecimento apresentar odor e gosto (AWWA, 1987).

As algas azuis além de potencialmente produtoras de toxinas ainda produzem substâncias que conferem gosto e odor nas águas de abastecimento. Isto acontece devido à presença de ácidos graxos nas células. Os lipídeos, quando extraídos das células, apresentam forte odor. A ação do cloro, formando clorofenóis, pode intensificar o odor e gosto da água causado pelas algas (Carvalho, 2003).

Dentre os aspectos estéticos a serem observados quanto ao fornecimento de água potável para fins de abastecimento público, não apenas as variáveis de cor e turbidez devem ser considerados em referencia a concepção e operação de estações de tratamento de água (ETA), mas, também, a possibilidade da água bruta vir a apresentar problemas de odor e gosto, metais, substâncias precursoras de organoclorados, etc, dependendo do manancial utilizado (Andrade et al., 2000).

Ainda segundo Carvalho (2003), certas algas ricas em compostos nitrogenados podem, ao entrar em decomposição sob a ação de fungos ou bactérias, produzir intenso mau cheiro, como é o caso de certas algas azuis, que embora possuam, enquanto vivas, um odor característico de grama ou capim (Microcystis), passam a apresentar, depois que entram em decomposição, um forte cheiro característico de esgoto séptico. Outros grupos de algas apresentam odor ou sabor de mofo, barro, e também de peixes. 


\subsection{TOXINAS}

As algas azuis possuem grande potencialidade em produzir toxinas. O mais antigo caso que se conhece de intoxicação de animais, relacionada com a floração de algas na água que bebiam, foi descrito em 1878 por George Francis, de Adelaide - Austrália, que mencionou a floração da alga azul Nodularia spumigena em lagos da Austrália (Branco, 1978). Schiwimmer \& Schiwimmer $(1964,1968)$ referem-se a lagos e reservatórios dos EUA. Há também citações para Europa, Ásia, África, Austrália e América do Sul (Beyruth et al., 1992).

Nem sempre as florações são formadas por espécies tóxicas e, mesmo tratando-se de espécies normalmente referidas como potencialmente tóxicas, estas podem não produzir as toxinas dependendo das condições ambientais. A floração pode ser uniforme ou ter partes tóxicas e outras não. Os mecanismos que atuam e controlam a sua toxicidade ainda não são bem conhecidos (Beyruth et al., 1992).

As toxinas dividem-se em duas modalidades que causam agravos orgânicos distintos: as hepatotoxinas e neurotoxinas. As hepatotoxinas são peptídeos de baixo peso molecular que afetam o fígado e são as causas mais comuns de envenenamento de animais por cianofíceas tais como: Cylindrospermopsis raciborskii, Microcystis aeruginosa, Nodularia spumigena e Oscillatoria agardhii. Os sintomas são vômitos, diarréias, dores de cabeça (Carvalho, 2003).

Carvalho (2003) diz que "algumas cepas ou linhagens de Microcystis aeruginosa, por exemplo, produzem uma endotoxina violentíssima que provoca a morte de camundongos em uma hora, quando inoculada na proporção de $0,5 \mathrm{mg}$ por quilo de peso animal. Essa toxina recebeu a denominação de FDF ("fast death factor"). Entretanto, todas as algas dessa espécie, inclusive as que não apresentam toxina própria, podem, ao entrar 
em decomposição, originar um ambiente anaeróbio propício ao desenvolvimento de certas bactérias tóxicas. Por essa razão, muitos autores que não constataram toxicidade em testes a partir de algas frescas, os obtiveram após incubação por períodos prolongados (24 a 36 horas) em ambientes de temperatura constante $\left(27^{\circ}\right.$ a $\left.35^{\circ} \mathrm{C}\right)$. Esta última distingue-se da primeira quanto aos seus efeitos sobre animais, agindo muito mais lentamente (a morte de camundongos infestados nunca se dá em menos de três horas), razão pela qual é denominado "fator causador de morte lenta".

As neurotoxinas são alcalóides e podem ser dos tipos - anatoxina (produzida por Anabaena flos-aquae) e aflatoxina (produzida por Aphanizomenon flos-aquae). Ambas são agentes bloqueadores neuromusculares e em animais podem causar a morte devido à paralisia dos músculos respiratórios. Essa neurotoxina se denominou VFDF ("very fast death factor") e caracteriza-se por uma ação tóxica extremamente violenta, podendo provocar a morte de um camundongo inoculado em até dez minutos (Carvalho, 2003).

Existem algumas evidências de que as toxinas de cianofíceas podem contribuir para o desenvolvimento de câncer. Por outro lado, pesquisas sobre a estrutura e atividade de toxinas têm demonstrado que estas podem ser utilizadas na medicina como por exemplo, na produção de medicamento para a doença de Alzheimeir (Carmichael, 1994). 


\section{CARACTERIZAÇÃO DA ÁREA DE ESTUDO}

\subsection{BACIA HIDROGRÁFICA DA REPRESA DO GUARAPIRANGA}

A Bacia do Guarapiranga possui uma área aproximada de $630 \mathrm{Km}^{2}$ inserida nos municípios de São Paulo, Embu, Itapecerica da Serra, EmbuGuaçu, Cotia, São Lourenço da Serra e Juquitiba. De acordo com a CETESB (1991) a represa encontra-se a 740 metros de altitude, possui área de drenagem de $631 \mathrm{~km}^{2}$, espelho d'água de $34 \mathrm{~km}^{2}$, profundidade média de 7 metros e máxima de 13 metros e geograficamente situa-se à latitude sul de $23^{\circ} 43^{\prime}$ e à longitude oeste $46^{\circ} 32^{\prime}$.

Sua finalidade, quando da sua construção entre os anos de 1906 e 1908, era a de regularizar as vazões dos rios Pinheiros / Tietê, de forma a aumentar a capacidade de geração da antiga Usina Parnaíba, localizada onde hoje se encontra a Barragem Edgard de Souza. A antiga usina passou de 2 para 12 MW, em 1912.

O aproveitamento desta fonte hídrica para o abastecimento público ocorreu a partir de 1927, por meio da captação de água próxima a sua barragem (Figura 7), e ela se tornou, durante muito tempo, o maior provedor de água da região metropolitana de São Paulo. Atualmente é o segundo maior sistema de potabilização de água na metrópole paulistana, produzindo em média $14 \mathrm{~m} / \mathrm{s}$, valor esse que representa $1 / 5$ do total consumido, provendo o abastecimento de $20 \%$ da população de São Paulo, cerca de 3,4 milhões de pessoas. 


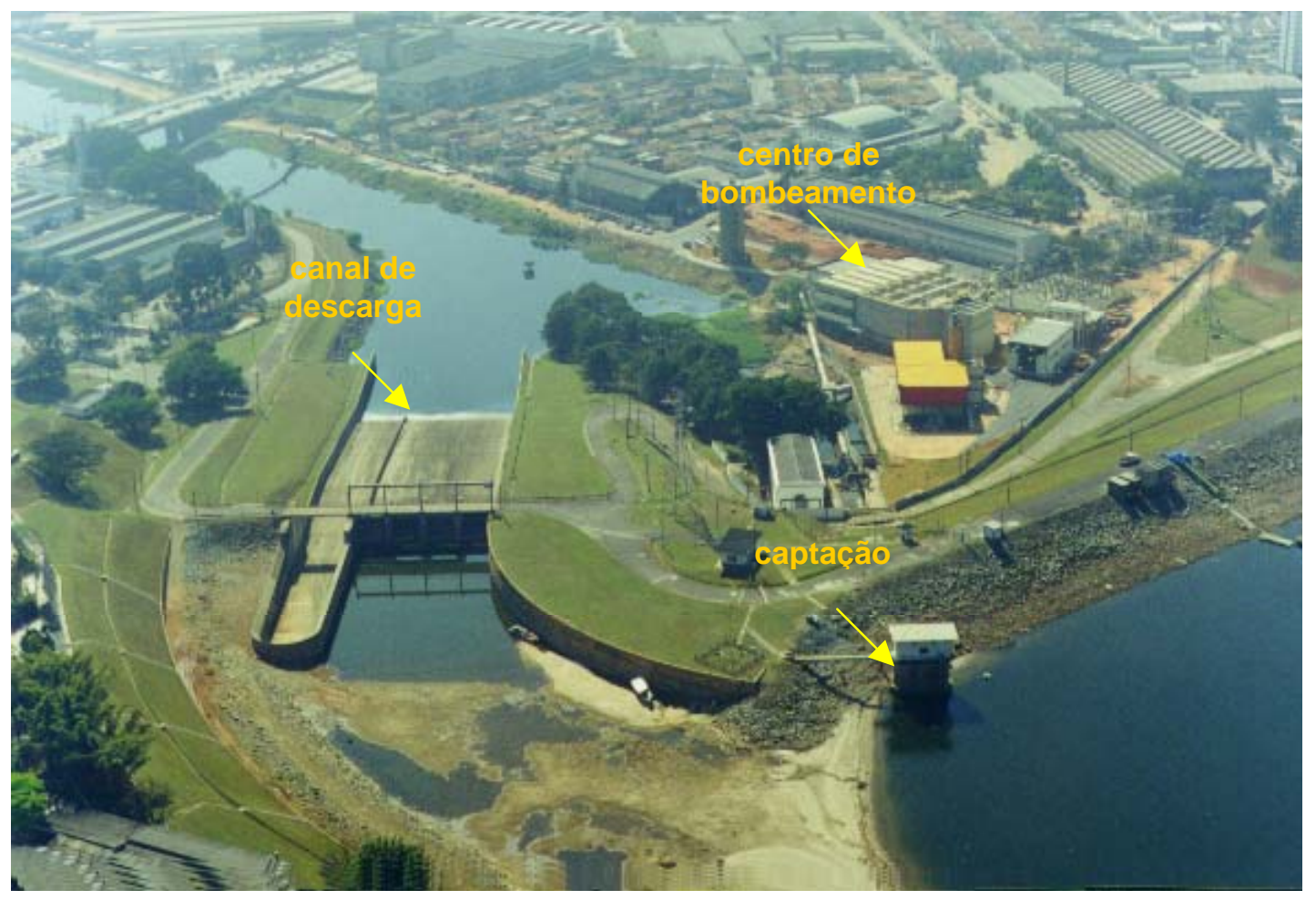

Figura 7. Vista da barragem da represa do Guarapiranga, instalações de captação, centro de bombeamento e canal de descarga (Fonte: acervo do autor, 2000).

A partir do final da década de 70 a represa do Guarapiranga começou a apresentar os sinais do comprometimento de qualidade de suas águas com a ocorrência de surgimentos de florações de algas, isto sendo função de um processo de eutrofização do corpo d'água, causado pelo inconseqüente aumento da ocupação do solo na região, acarretando aumento significativo do aporte de nutrientes ao longo da represa. $O$ resultado destes fenômenos sazonais contribuiu para o comprometimento do processo de potabilização das águas deste manancial, com problemas de redução do desempenho do sistema de tratamento.

Em meados dos anos 80 começou-se a perceber que o sistema de abastecimento Guarapiranga cobrava uma demanda de distribuição maior que a oferta de produção de água. O manancial possuía uma vazão regularizada de reposição hídrica de $10,3 \mathrm{~m}^{3} / \mathrm{s}$, sendo 9,6 naturais e mais $0,7 \mathrm{~m}^{3} / \mathrm{s}$ revertidos do rio Capivari. 
No início dos anos 90 era iminente a necessidade de aumento da capacidade de fornecimento de água, vislumbrando-se em conseqüência da necessidade, a transposição de água da represa Billings que tem sua bacia vizinha a do Guarapiranga, aumentando-se assim a capacidade de regularização hídrica da represa do Guarapiranga, o que tornaria possível o aumento de sua exploração. A partir de 1999 o sistema passou a conviver com um severo período de estiagem (Figura 8) chegando no ano seguinte próximo ao nível mínimo operacional de exploração do manancial. A partir de agosto de 2000 as águas da Billings passaram a ser transpostas para a represa do Guarapiranga. A possível ocorrência de efeitos relacionados à mudança das características da água da represa do Guarapiranga passou a ser avaliada através de um plano de contingência para a qualidade de água (anexo 1).

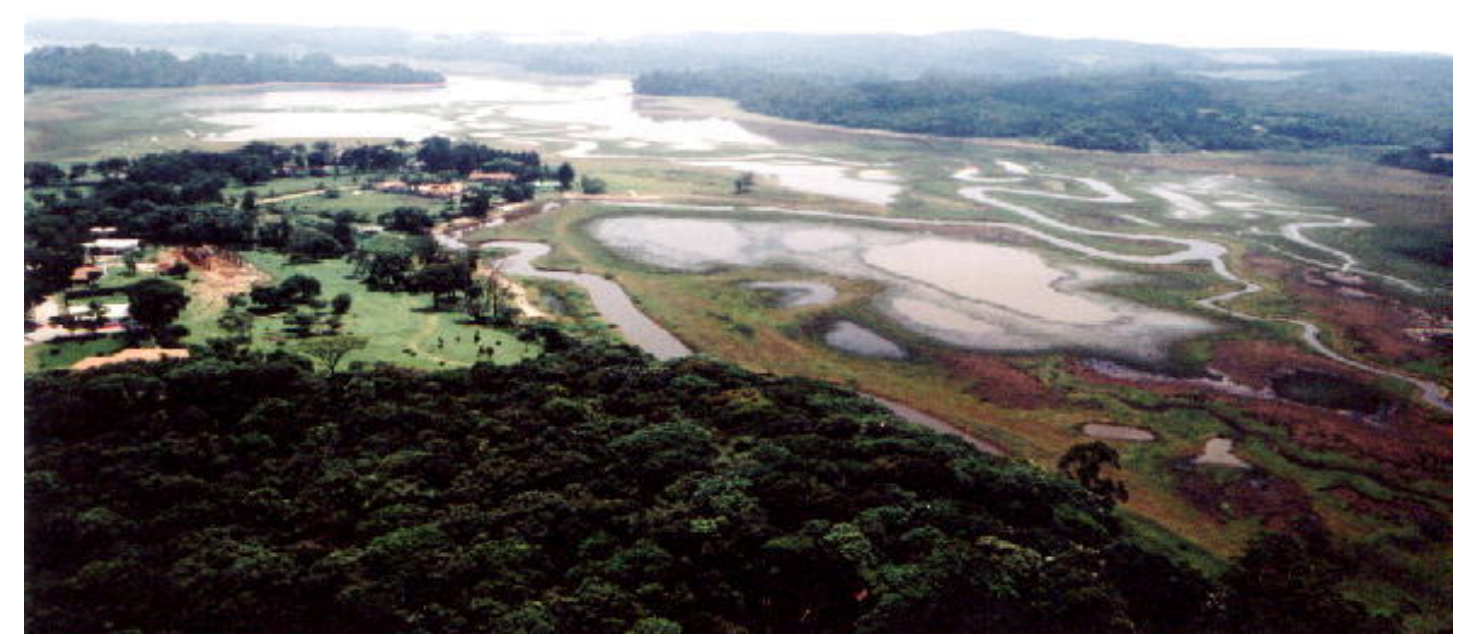

Figura 8. Ponto de afluência do rio Embu-Guaçu (principal afluente natural do Guarapiranga). A imagem retrata o estado da várzea em período de estiagem (Fonte: acervo do autor, 2000). 


\subsection{BACIA HIDROGRÁFICA DA REPRESA BILLINGS}

A bacia hidrográfica da represa Billings ocupa uma área de 582,8 km², localizada na Região Metropolitana de São Paulo, sendo limitada, a oeste, com a bacia hidrográfica da represa do Guarapiranga e, ao sul, com a Serra do Mar. Sua área de drenagem abrange os municípios de Rio Grande da Serra, Diadema, Ribeirão Pires, Santo André, São Bernardo do Campo e São Paulo.

A represa Billings é o maior reservatório de água da Região Metropolitana de São Paulo. Seu espelho d' água possui 108 km², correspondendo a $18 \%$ da área total de sua bacia hidrográfica. O nível d'água do reservatório é bastante variável em função do bombeamento das águas dos rios Tietê e Pinheiros. O nível de água máximo normal é na cota 747,65 , conforme dados do IBGE (HIDROPLAN, 1995).

A partir da década de 50, a represa passou a receber águas revertidas de outra bacia, por meio do canal do rio Pinheiros, com o intuito de aumentar a potência instalada na usina elétrica de Henry Borden, que chegou então a 880 MW. Porém, o aumento populacional da região metropolitana de São Paulo acarretou uma piora de qualidade das águas revertidas do rio Pinheiros, que atravessa esta região urbana da cidade de São Paulo. Conseqüentemente a represa passou a apresentar redução na qualidade de sua água.

As águas desta represa apresentaram sinais de deterioração a partir da década de 50, originada pelo bombeamento contínuo das águas dos rios Tamanduateí, Tietê e Pinheiros, sendo esses possuidores de alta carga de poluentes e contaminantes de origem doméstica e industrial (Sendacz et al., 1999). É fato que o reservatório vem recebendo, desde há muito tempo, diversos resíduos líquidos e sólidos de diversas fontes domésticas e industriais. 
Em 1982, devido à grande quantidade de esgotos que continuavam sendo lançados pela reversão dos rios e ainda dos oriundos de assentamentos urbanos irregulares na bacia (Figura 9) e o surgimento de grandes florações de algas cianofíceas (Figura 10), as quais são reconhecidas por seu potencial tóxico, indicaram a necessidade de interceptação total do braço do Rio Grande, através da construção da Barragem do Rio Grande (Figura 11), para garantir o abastecimento de água para a população abrangida por este sistema.

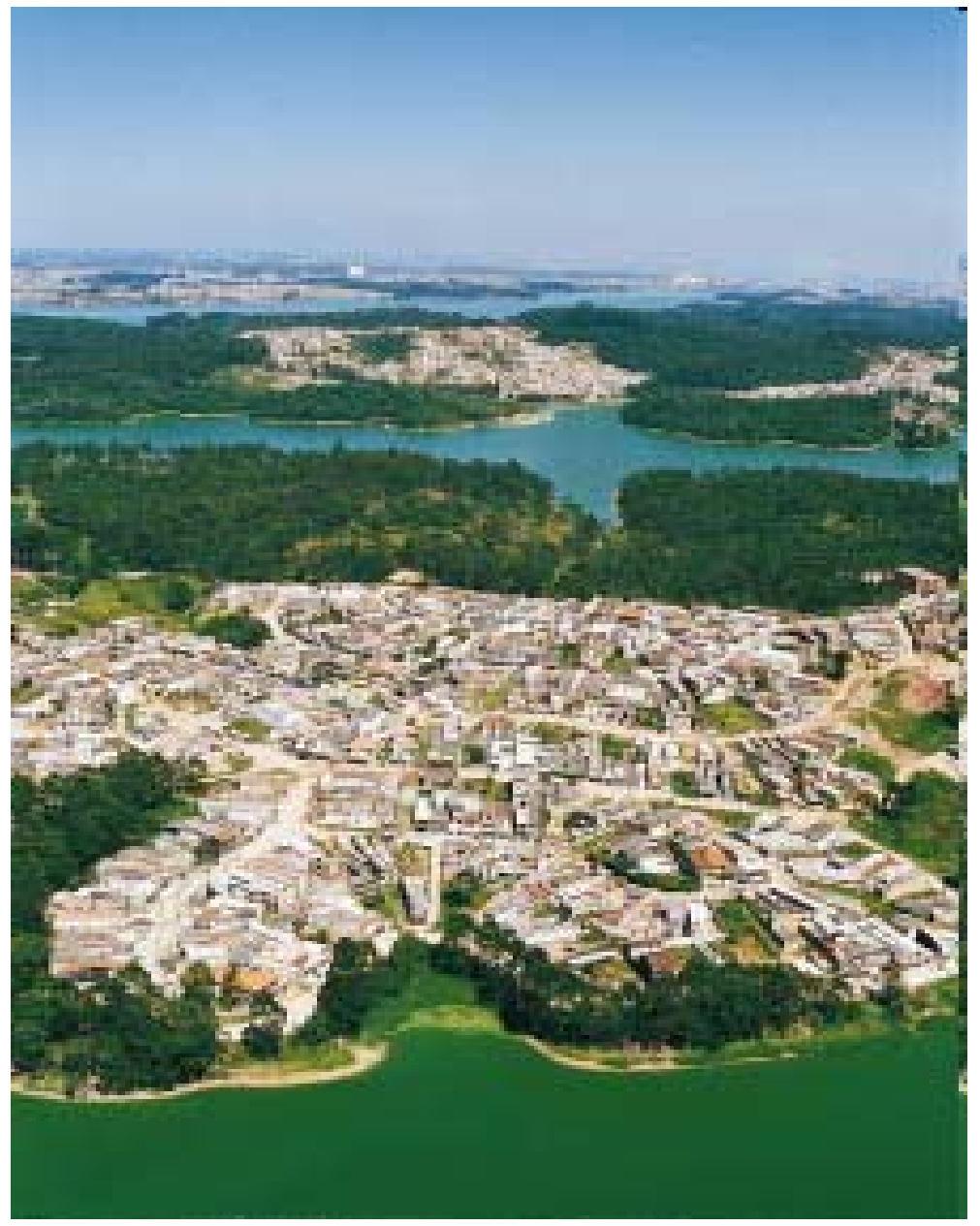

Figura 9. Ocupações irregulares na bacia Billings (Fonte: Capobianco, 2002). 


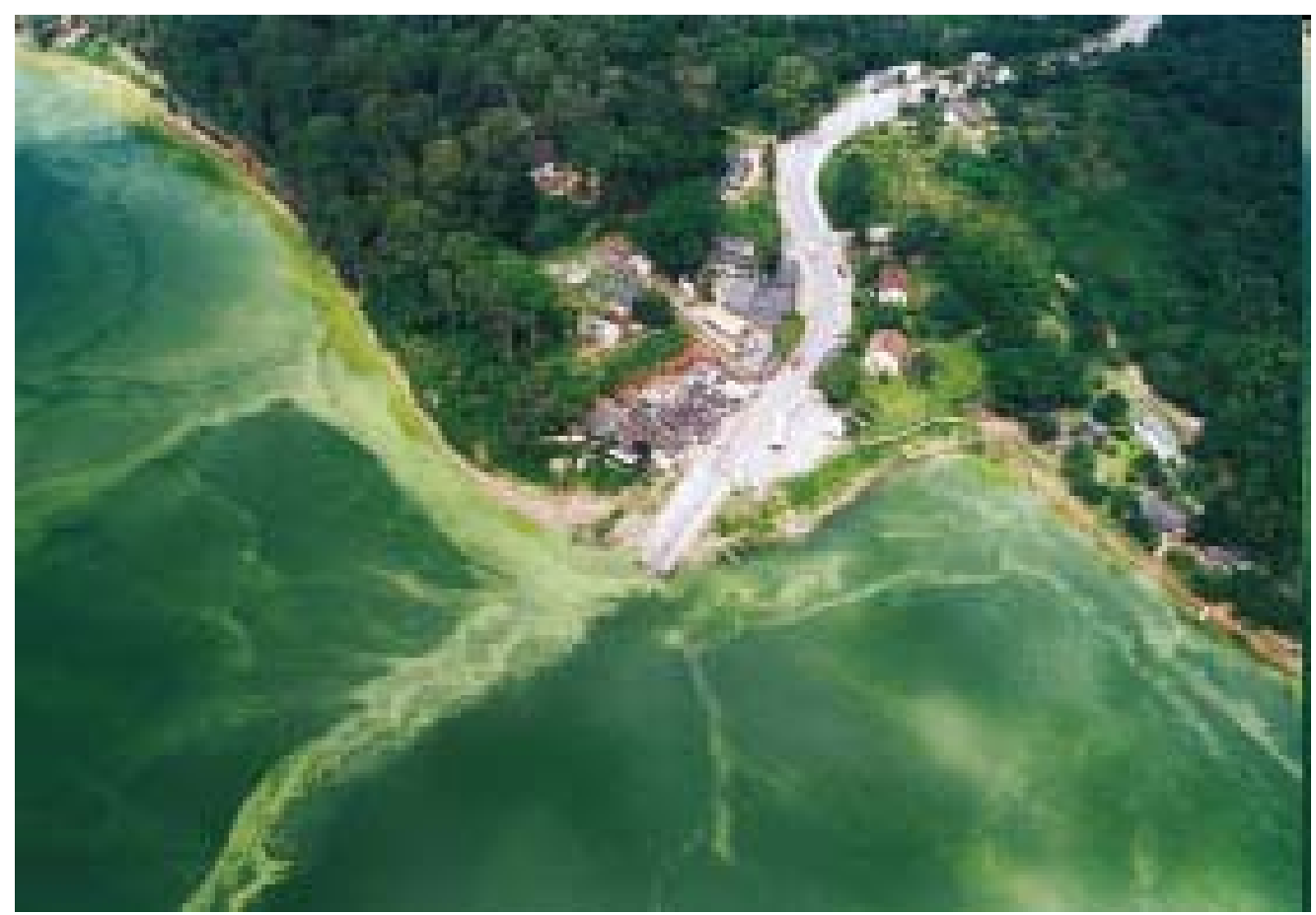

Figura 10. Florações de algas no braço Bororé da represa Billings (Fonte: Capobianco, 2002).

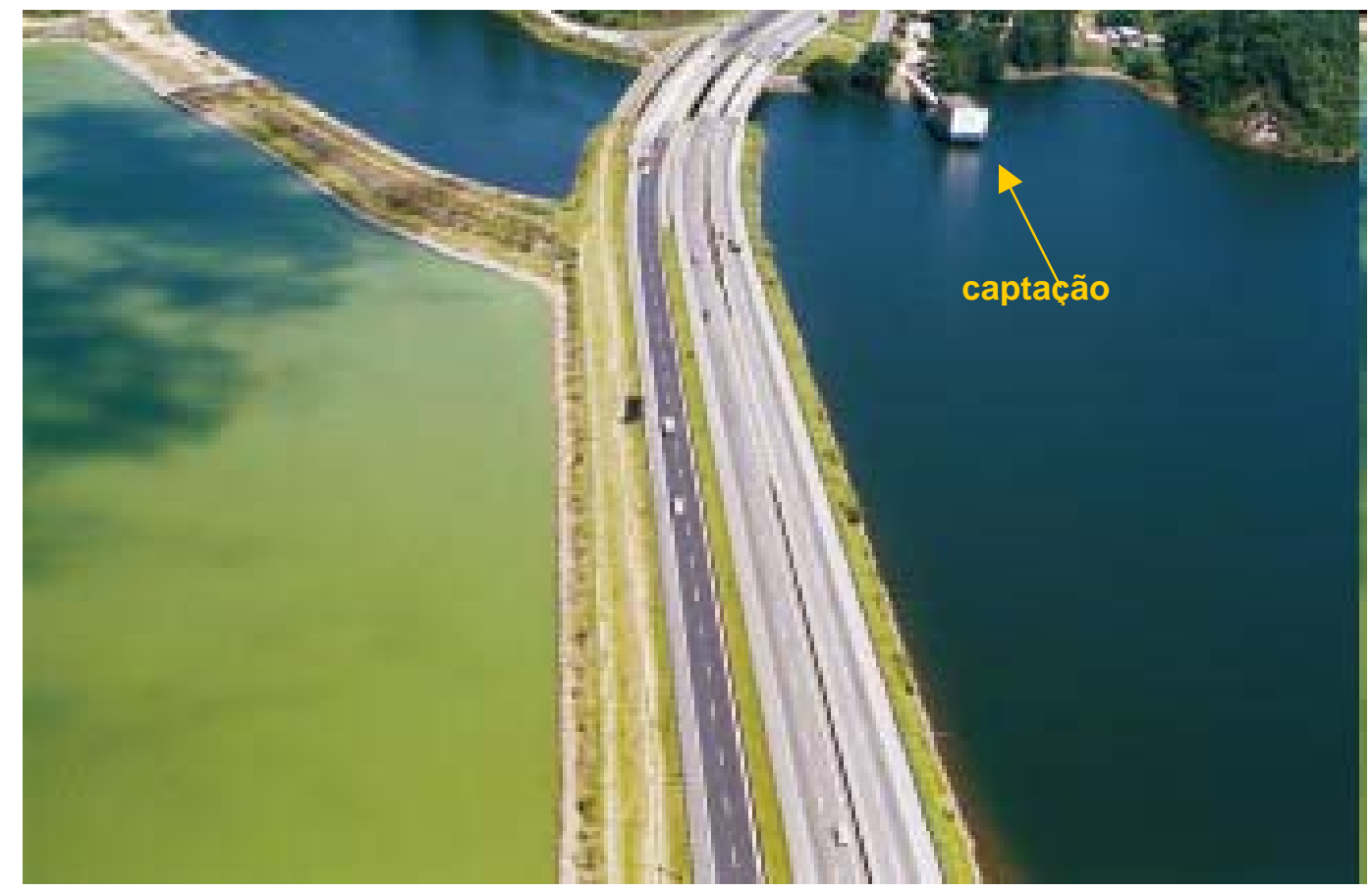

Figura 11. Compartimentação do braço Rio Grande "captação de água a direita ao fundo" (Fonte: Capobianco, 2002). 
Em 1992 a Secretaria Estadual do Meio Ambiente aprovou Resolução restringindo o bombeamento a situações emergenciais, entre as quais ameaças de enchente e risco de colapso na produção de energia elétrica. O bombeamento das águas do Tietê para a Billings continua a ser utilizado, até os dias de hoje, como alternativa de controle de cheias em períodos de chuvas intensas na cidade de São Paulo (Capobianco, 2000).

A primeira iniciativa para a ampliação do uso da represa Billings para o abastecimento, utilizando outras áreas da represa além do Braço do Rio Grande, foi a sua interligação com a represa Guarapiranga, através da transposição de águas captadas na Billings em um de seus braços, 0 Taquacetuba, cuja operação de bombeamento teve início em agosto de 2000.

Este empreendimento originou, a época de seu projeto e instalação, uma discussão envolvendo a Sabesp, responsável pela implantação do empreendimento, a Secretaria do Meio Ambiente - SMA, responsável pelo licenciamento ambiental, o Ministério Público de São Paulo, ambientalistas e pesquisadores (Capobianco, 2000). Havia a necessidade do acompanhamento de possíveis impactos causados a represa do Guarapiranga, originados a partir da transposição de águas de uma represa (Billings) com características limnológicas bastante adversas.

\subsection{VÁRZEA DO RIBEIRÃO PARELHEIROS}

O ribeirão Parelheiros aflui para a represa do Guarapiranga formando a várzea (Figura 12 e 13) que leva seu nome, ocupando aproximadamente 93 hectares e tendo ainda como contribuinte significativo o córrego Itaim, ambos (ribeirão e córrego) com considerável degradação hídrica, decorrente de grande aporte de esgotos domésticos. 


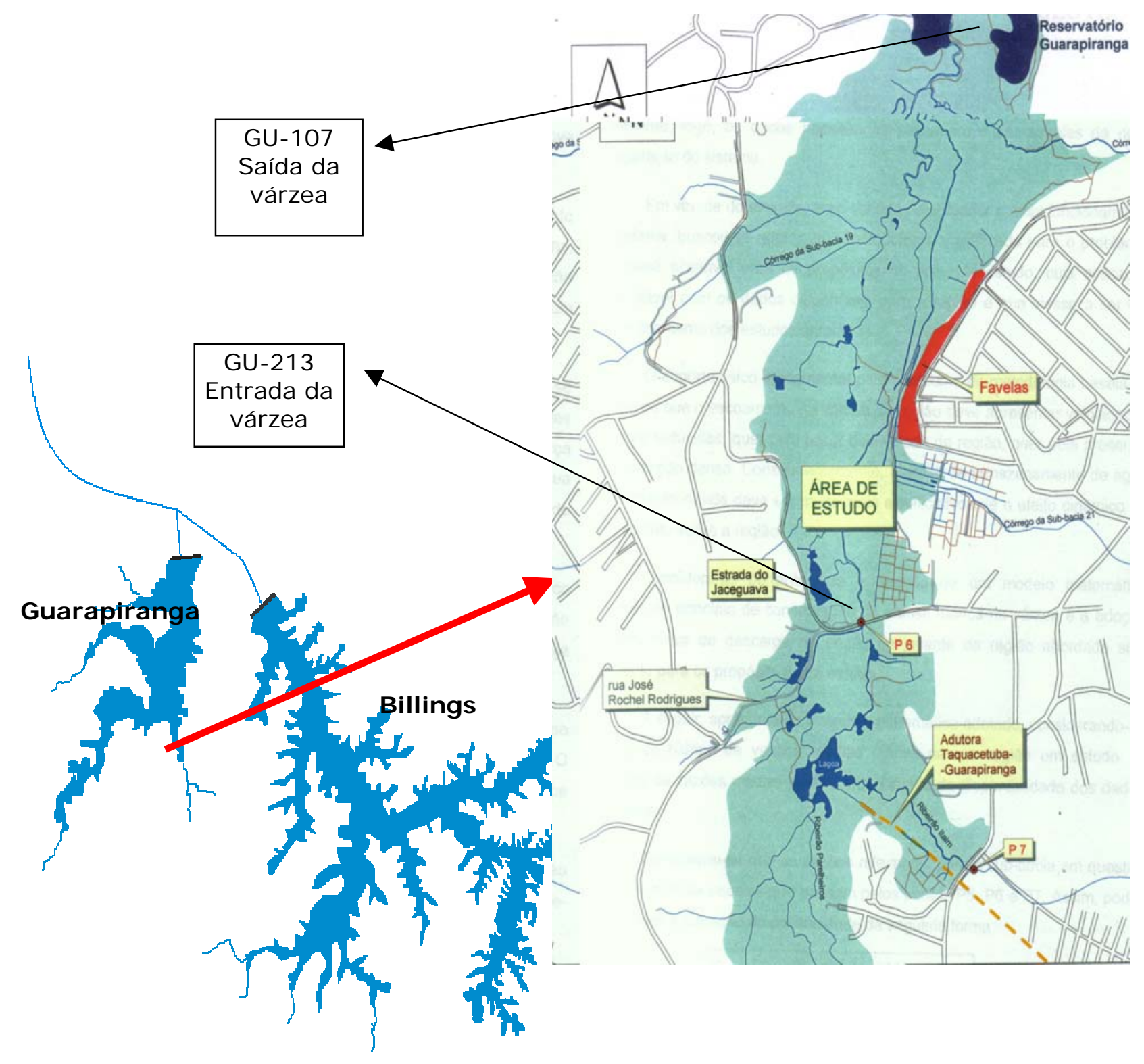

Figura 12. Várzea do ribeirão Parelheiros, imagem de caracterização da área de estudo (Fonte: acervo do autor, 2000). 


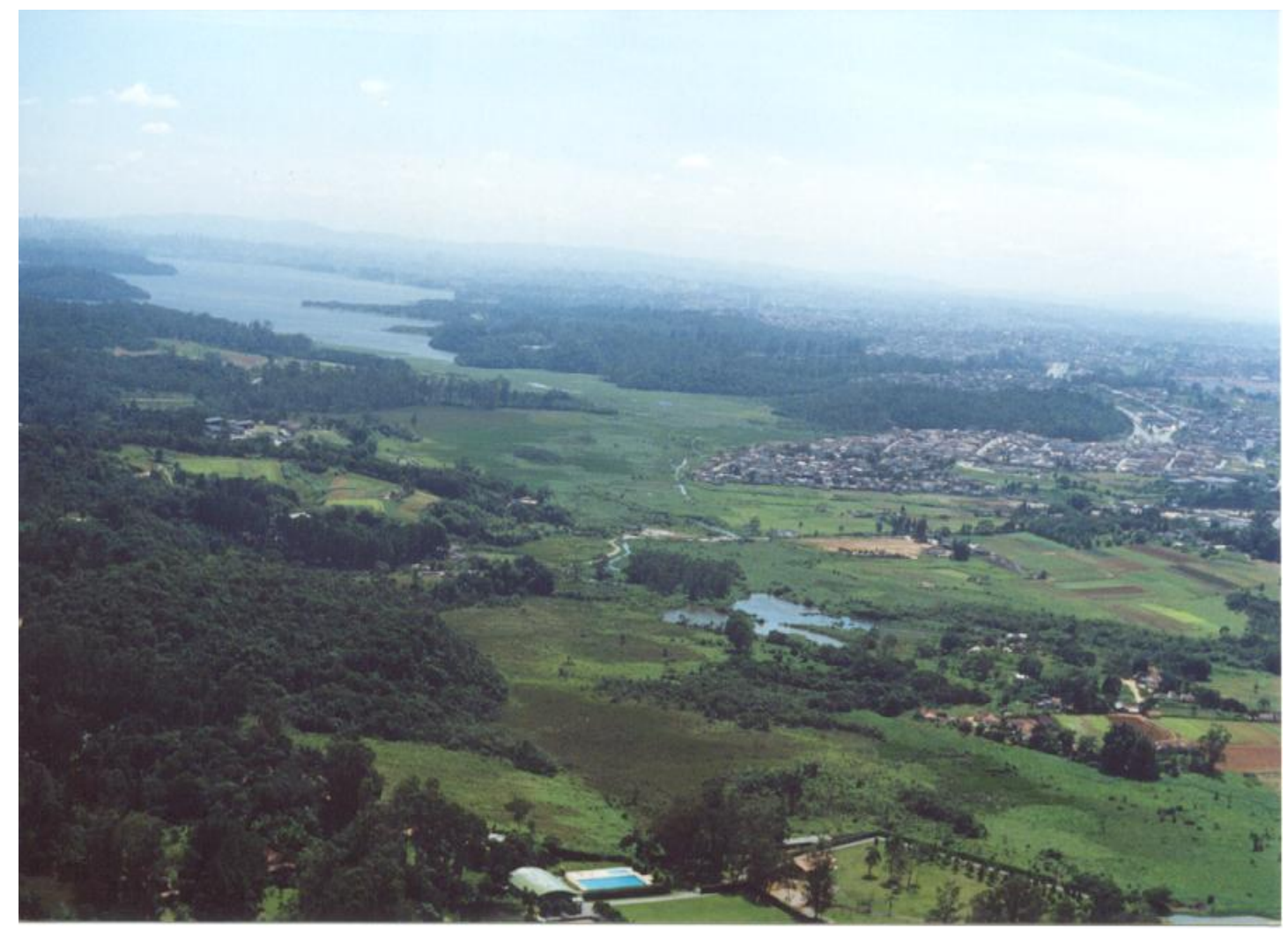

Figura 13. Várzea do ribeirão Parelheiros verificando-se, ao fundo, a represa do Guarapiranga (Fonte: acervo do autor, 2000).

O regime hidrodinâmico desta várzea pode ter sofrido severas alterações a partir da sua utilização em agosto de 2000 como área receptora da transposição de águas da represa Billings (Figura 14), operação está que contribui com uma vazão exógena de em média $4,0 \mathrm{~m}^{3} / \mathrm{s}$ de água com grande comprometimento hidrobiológico, uma vez que a represa de origem tem alto grau de eutrofização e constantes florações de cianobactérias. 


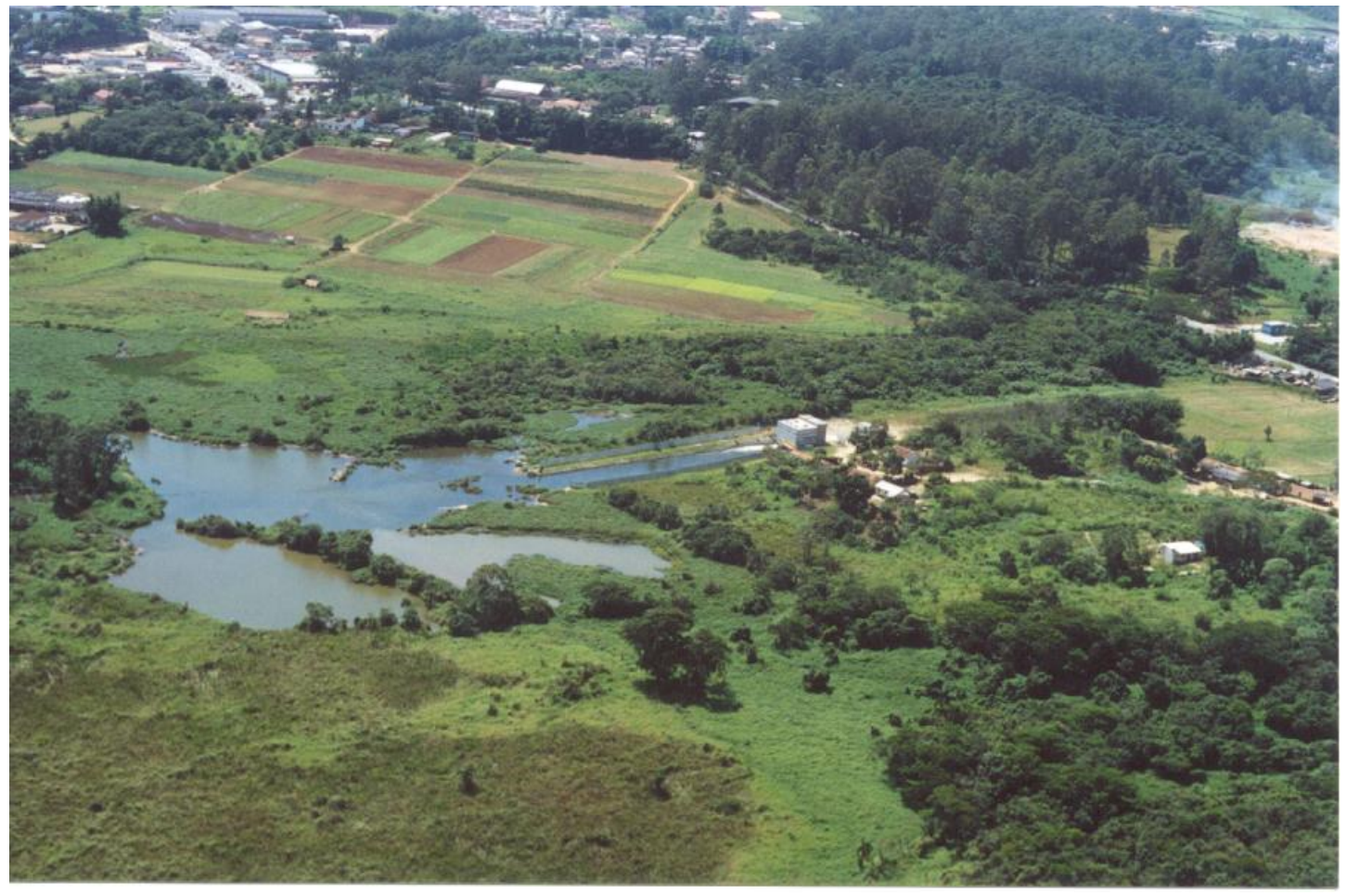

Figura 14. Vista do canal de recepção de água da Billings (Fonte: acervo do autor, 2003).

O canal de recepção da água transposta localiza-se paralelo a afluência do Córrego Itaim e a aproximadamente 2000 metros a montante do reservatório. Podem ser facilmente observados pontos de grande alteração antrópica que envolvem desde atividades já extintas de mineração, movimentação de terra para fins agrícolas (Figura 15), de lazer (futebol de várzea) e invasões imobiliárias clandestinas (Figura 16). 


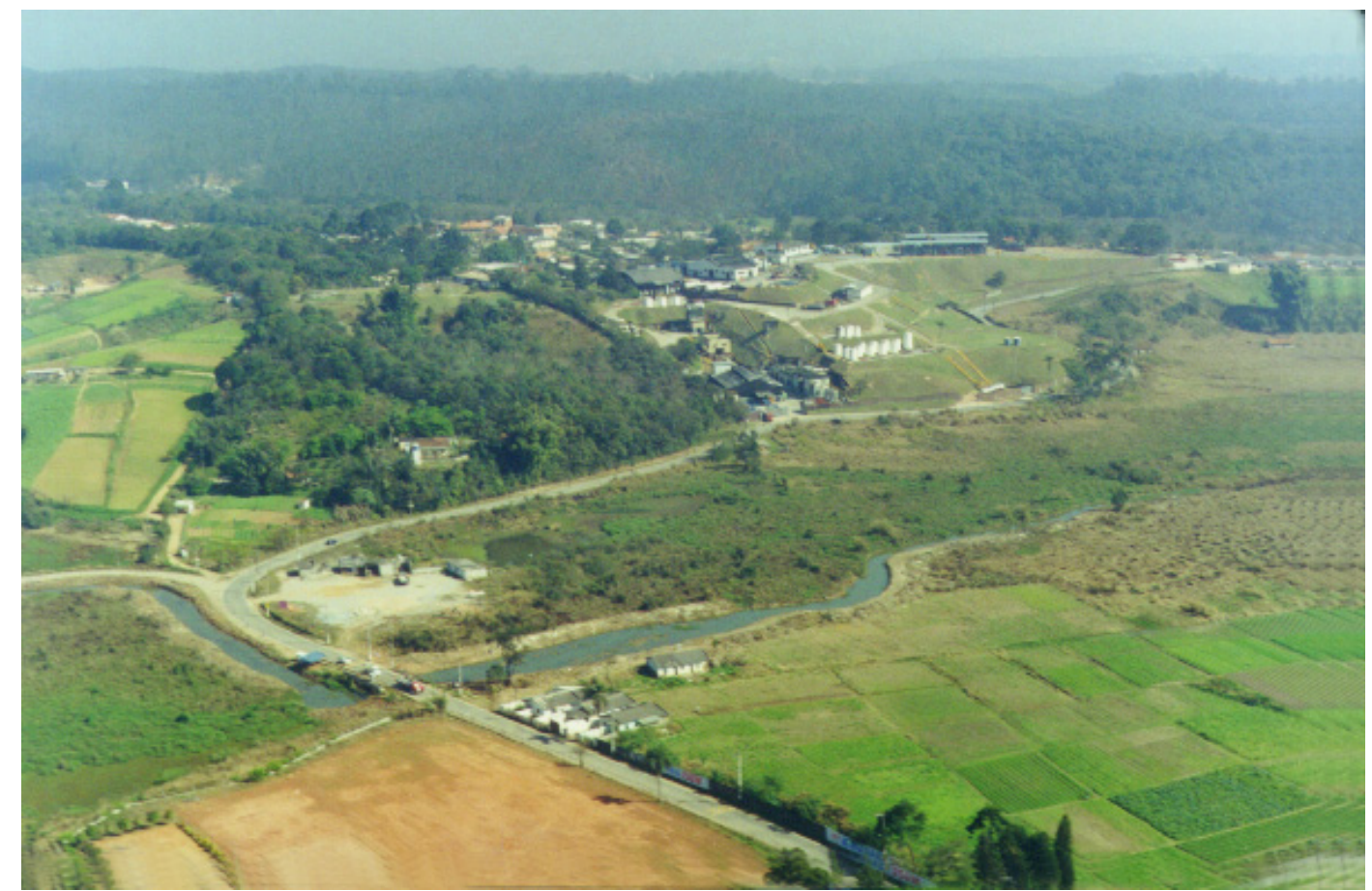

Figura 15. Invasão da várzea para uso agrícola (Fonte: acervo do autor, 2000).

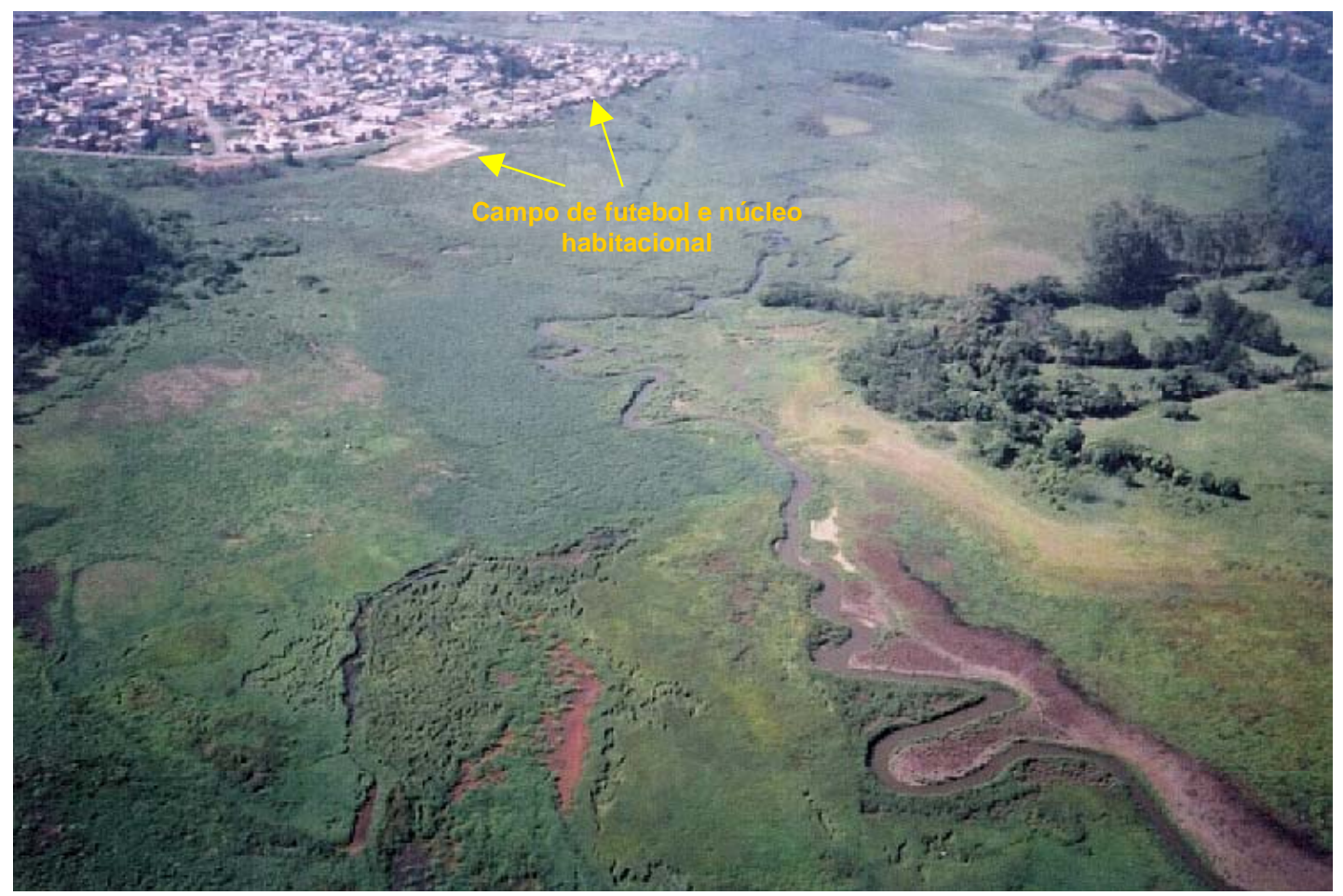

Figura 16. Núcleo habitacional e campo de futebol invadindo a várzea (Fonte: acervo do autor, 2000). 
Segundo avaliação de Geotec (2001), "as águas dos rios e riachos que chegam à várzea, drenam a sua bacia, a qual possui diversos núcleos habitacionais, alguns legalmente constituídos, outros não. Essas ocupações dispõem ou não de sistemas de coleta e afastamento de esgotos sanitários. Uns contam com sistemas implantados, outros estão em áreas com sistemas em implantação ou em projeto. Além disso, deve-se destacar que mesmo em áreas que já contam com sistemas coletores existem aqueles que relutam em utilizar o serviço já que isso representa um dispêndio mensal". Desta forma a várzea apresenta-se bastante alterada, a influência antrópica é marcante.

A várzea apresenta cobertura vegetal bastante diversificada possuindo áreas homogêneas com espécies de gramíneas até fragmentos florestais. Sua vegetação é formada principalmente de plantas herbáceas, ocorrendo plantas higrófitas em local de maior umidade, principalmente ao norte da várzea, aos limites do nível d'água da represa. Dentre as plantas higrófitas ocorrentes na várzea são predominantes às espécies Panicum rivulare (capim-santa-fé) e Typha angustifólia (taboa), com cobertura estimada em torno de 50\% e 20\% respectivamente (Geotec, 2001).

A espécie Panicum rivulare (capim-santa-fé) é uma planta herbácea, perene, cespitosa, ereta, de colmos cilíndricos e fistulosos, nativa da América do Sul. Considerada daninha por seu comportamento invasor, ocorre freqüentemente em locais chuvosos e alagados (Lorenzi, 2000 apud Geotec 2001).

A segunda espécie ocorrente, "Typha angustifólia (taboa) é nativa da América do Sul e Central, bastante comum em lugares alagados. É uma planta herbácea, perene, ereta, fortemente rizomatosa, aquática e de terrenos pantanosos. A condição pedológica ideal para seu desenvolvimento é representada por solos com alto teor de matéria orgânica. Segundo 
Lorenzi (2000) apud Geotec (2001), esta espécie absorve metais pesados, inclusive cobre, podendo contribuir para o saneamento ambiental".

Nas várzeas um dos principais fatores para o processo de depuração hídrica é a vegetação aquática. As macrófitas aquáticas removem nutrientes através da assimilação direta e ainda oferecem substratos para microorganismos, como bactérias e fungos, que degradam compostos orgânicos solúveis (Hatano et al., 1993).

As espécies mais freqüentes encontradas na várzea além das já citadas são as herbáceas higrófitas Polygonum lapathifolium (Cataia gigante), Hedychium coronarium (Lírio do brejo), Melinus minutiflora (Capim gordura), as macrófitas emersas Ludwigia octovalvis (Cruz de malta), Heteranthera sp. (Agriãozinho), Polygonum sp. (Erva de bicho), Eleocharis nodulosa (Junco), as macrófitas submersas enraizadas Myriophyllum brasiliense (Pinheirinho d'água), as macrófitas submersas livres Utricularia $s p$. (Utricularia) e as macrófitas flutuantes Eichhornia crassipes (Aguapé), Pistia stratiotes (Alface d'água), Salvinia auriculata (Samambaia d'água), (Geotec 2001). 


\section{PROCEDIMENTOS METODOLÓGICOS}

Foi analisado o desempenho da várzea por meio da comparação dos resultados dos valores médios, máximos e mínimos referentes ao período de junho de 2003 a março de 2004, agrupados em período seco e chuvoso das variáveis físicas e químicas (nitrogênio, fósforo, $\mathrm{pH}$, turbidez, cor e demanda química de oxigênio), toxicológicas (Microcistina) e biológicas (Coliformes totais e fecais e contagem de algas cianofíceas), previstos no plano de monitoramento de rotina da Sabesp e no Plano de Contingência para Cianobactérias do Sistema Produtor Taquacetuba/Guarapiranga (anexo 1), da água afluente e efluente a Várzea do Ribeirão Parelheiros (Figura 17).

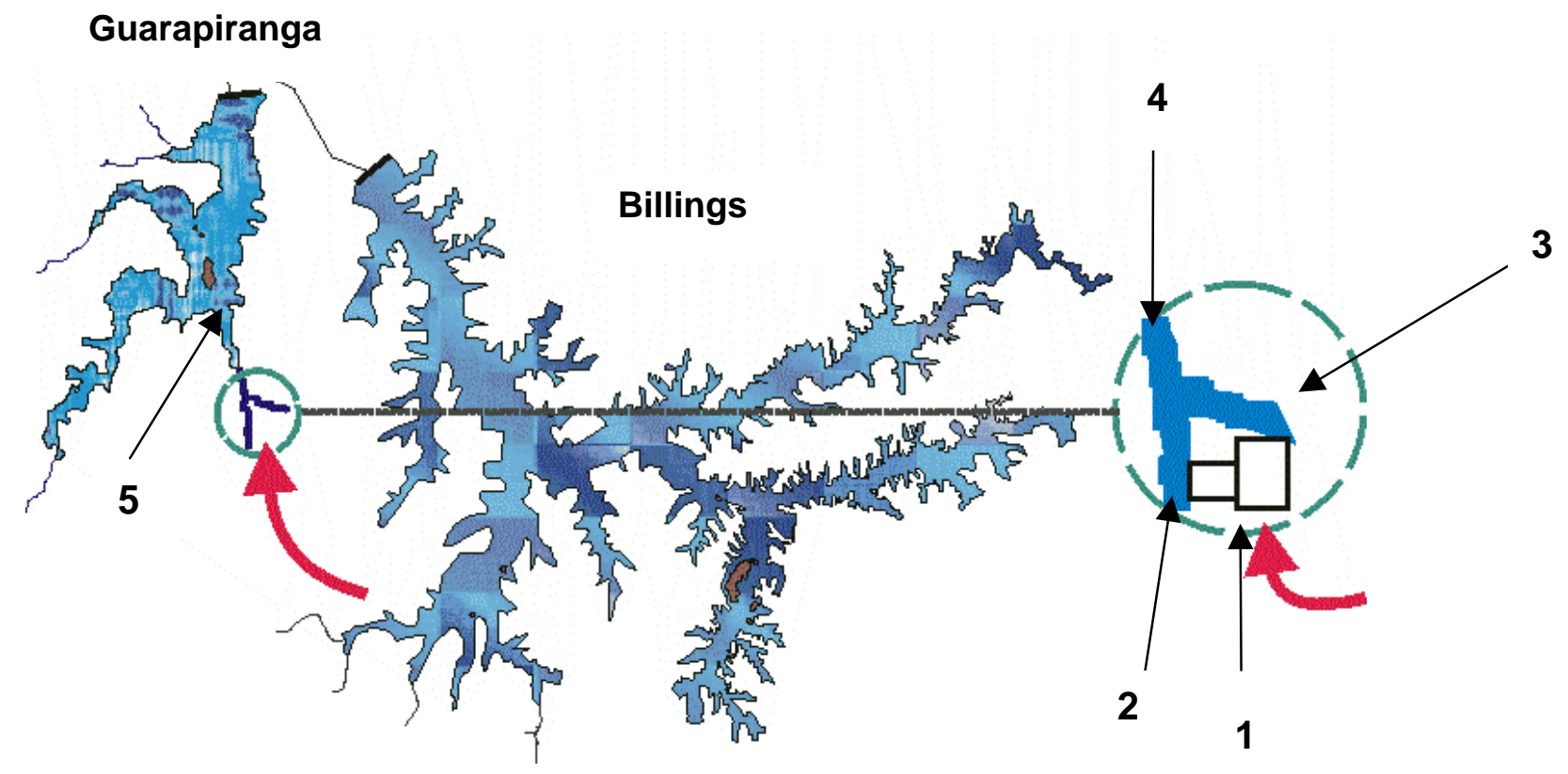

1 - chegada da água transposta da Billings

2 - Ribeirão Parelheiros

3 - Ribeirão Itaim

4 - Início da Várzea - (GU 213) ponto de amostragem

5 - Saída da várzea - (GU 207) ponto de amostragem

Figura 17. Esquema ilustrativo do sistema integrado Guarapiranga/Billings (Fonte: SABESP - s/data). 
As metodologias utilizadas nas coletas e análises seguem a determinação do Ministério da Saúde, através da PORTARIA N. ${ }^{\circ}$ 1469, atual portaria 518 , de 29 de dezembro de 2000 , que estabelece os procedimentos e responsabilidades relativas ao controle e vigilância da qualidade da água para consumo humano e seu padrão de potabilidade, em seu artigo 17 , § $1^{\circ}$, conforme segue:

"Art. 17. As metodologias analíticas para determinação dos parâmetros físicos, químicos, microbiológicos e de radioatividade devem atender às especificações das normas nacionais que disciplinem a matéria, da edição mais recente da publicação Standard Methods for the Examination of Water and Wastewater, de autoria das instituições American Public Health Association (APHA), American Water Works Association (AWWA) e Water Environment Federation (WEF) ou das normas publicadas pela ISO (International Standartization Organization).

§ $1^{\circ}$ Para análise de cianobactérias e cianotoxinas e comprovação de toxicidade por bioensaios em camundongos, até o estabelecimento de especificações em normas nacionais ou internacionais que disciplinem a matéria, devem ser adotadas as metodologias propostas pela Organização Mundial da Saúde (OMS) em sua publicação Toxic cyanobacteria in water: a guide to their public health consequences, monitoring and management".

As metodologias analíticas utilizadas pela Sabesp se enquadram na exigência descrita acima, sendo realizadas a contagem de algas através do método de microscopia de Sedgwick Rafter e a determinação de Microcistina através de imunoensaio pelo método ELISA. 


\section{APRESENTAÇÃO E ANÁLISE DOS RESULTADOS}

\subsection{INTRODUÇÃo}

Os resultados apresentados são provenientes do cálculo de valores médios, máximos e mínimos do banco de dados de qualidade de água do monitoramento realizado pela Sabesp, no período de junho de 2003 a marco de 2004, da várzea do Parelheiros, agrupados em período seco (junho, julho, agosto e setembro de 2003) e chuvoso (outubro, novembro e dezembro de 2003, janeiro, fevereiro e março de 2004).

Os dados diários de qualidade de água da entrada da várzea são apresentados no anexo 2, sendo que os dados de saída encontram-se no anexo 3. O anexo 4 contém todos os dados diários de pluviometria correspondentes a bacia do Guarapiranga obtidos para este fim e no anexo 5 são apresentados os dados diários de vazão de água da entrada da várzea.

Cogitou-se em comparar as variâncias através da utilização do teste $\mathrm{T}$, para os dados de nitrogênio e fósforo totais, porém o teste $\mathrm{t}$ não foi aplicável para estas variáveis porque os dados não parecem seguir distribuição normal. Não há diferença significativa entre os dados de entrada e saída da várzea, tanto para o período seco como para o período chuvoso. Para as demais variáveis de qualidade as diferenças apresentadas entre as médias permitiram analisar claramente o desempenho da várzea.

A Tabela 3 condensa os valores médios de todas as variáveis de qualidade e ainda de vazão e precipitação, nos períodos seco e chuvoso. Foi calculada a eficiência do sistema para cada variável de qualidade, onde os resultados negativos correspondem à verificação de aumento da concentração da respectiva variável entre a entrada e a saída da várzea. 
Tabela 3. Valores médios das variáveis obtidos na entrada (GU213) e Saída (GU107) da várzea do Parelheiros, incluindo-se vazão e precipitação, nos períodos seco e chuvoso.

\begin{tabular}{|c|c|c|c|c|c|c|c|}
\hline \multirow{3}{*}{ Variável } & \multirow{2}{*}{\multicolumn{2}{|c|}{$\frac{\text { GU213 }}{\text { Entrada }}$}} & \multirow{2}{*}{\multicolumn{2}{|c|}{$\begin{array}{c}\text { GU107 } \\
\text { Saída }\end{array}$}} & \multirow{2}{*}{\multicolumn{3}{|c|}{ Eficiência \% }} \\
\hline & & & & & & & \\
\hline & seco & chuvoso & seco & chuvoso & seco & chuvoso & média \\
\hline Fósforo total (mg/L) & 0,15 & 0,12 & 0,19 & 0,16 & $-26,7$ & $-33,3$ & $-30,0$ \\
\hline Nitrogênio total (mg/L) & 1,53 & 1,05 & 1,85 & 1,55 & $-20,9$ & $-47,6$ & $-34,3$ \\
\hline DQO (mg/L) & 30 & 28 & 22,3 & 23,35 & 25,7 & 16,6 & 21,1 \\
\hline Cor (mg/L) & 44 & 49 & 43 & 43 & 2,3 & 12,2 & 7,3 \\
\hline Turbidez (mg/L) & 7,4 & 11,8 & 5 & 7,5 & 32,4 & 36,4 & 34,4 \\
\hline $\mathrm{pH}$ & 7,9 & 8,1 & 7,1 & 7,2 & 10,1 & 11,1 & 10,6 \\
\hline Coli totais (NMP/100 mL) & $2,0 \mathrm{E}+05$ & $4,3 E+04$ & $1,1 E+05$ & $1,4 E+05$ & 42,8 & $-219,3$ & $-88,2$ \\
\hline Coli fecais (NMP/100 mL) & $5,3 E+03$ & $9,7 E+03$ & $2,2 E+04$ & $2,6 E+04$ & $-315,3$ & $-172,8$ & $-244,0$ \\
\hline Cianofíceas totais (cél/mL) & $3,2 E+05$ & $5,0 \mathrm{E}+05$ & $1,1 E+05$ & $2,1 \mathrm{E}+05$ & 66,1 & 57,5 & 61,8 \\
\hline Microcistina $(\mu \mathrm{g} / \mathrm{L})$ & 0,39 & 3,47 & 0,17 & 0,78 & 56,4 & 77,5 & 67,0 \\
\hline Vazão (m³/s) & 4,2 & 4,73 & & & & & \\
\hline Precipitação (mm) & 0,8 & 4,6 & & & & & \\
\hline Precipitação acumulada (mm) & 23,4 & 139,1 & & & & & \\
\hline
\end{tabular}

\subsection{PLUVIOSIDADE}

Pela análise dos dados pluviométricos do período de junho/2003 a março/2004, apresentados na Tabela 4 e nas Figuras 18 e 19, observa-se que o período seco compreendeu os meses junho, julho, agosto e setembro de 2003 e o período chuvoso correspondeu aos meses de outubro, novembro e dezembro de 2003 e janeiro, fevereiro e março de 2004.

Os dados pluviométricos definem perfeitamente o período seco e chuvoso, ou seja: há uma distinção bem clara entre eles, o que é altamente desejável para a análise comparativa de dados de ambos. Os meses de outubro e novembro de 2005 podem ser ainda observados como meses de transição entre os períodos seco e chuvoso, porém destacam-se dos meses 
secos uma vez que a precipitação acumulada é em média três vezes superior as do período seco.

Tabela 4. Valores máximos, mínimos, médios, acumulados e desvios padrão da variável pluviometria da bacia.

\begin{tabular}{|c|c|c|c|c|}
\hline \multirow{2}{*}{$\begin{array}{c}\text { Meses secosI } \\
\text { chuvosos }\end{array}$} & \multicolumn{4}{|c|}{ Pluviometria (mm) } \\
\cline { 2 - 5 } & $\max$ & min & Méd & acumulado \\
\hline jun/03 & 5,4 & 0,0 & 0,5 & 16,3 \\
jul/03 & 11,8 & 0,0 & 0,6 & 17,6 \\
ago/03 & 12,4 & 0,0 & 0,9 & 26,5 \\
set/03 & 17,2 & 0,0 & 1,1 & 33,0 \\
\hline Média & & & 0,8 & 23,4 \\
Desvio Padrão & & & 0,3 & 7,9 \\
\hline out/03 & 21,0 & 0,0 & 2,2 & 69,2 \\
nov/03 & 11,0 & 0,0 & 2,2 & 65,1 \\
dez/03 & 32,6 & 0,0 & 4,0 & 124,6 \\
jan/04 & 26,2 & 0,0 & 5,0 & 154,2 \\
fev/04 & 36,2 & 0,0 & 5,8 & 168,0 \\
mar/04 & 26,6 & 0,0 & 3,5 & 109,6 \\
\hline Média & & & 4,6 & 139,1 \\
Desvio Padrão & & & 1,5 & 42,6 \\
\hline
\end{tabular}




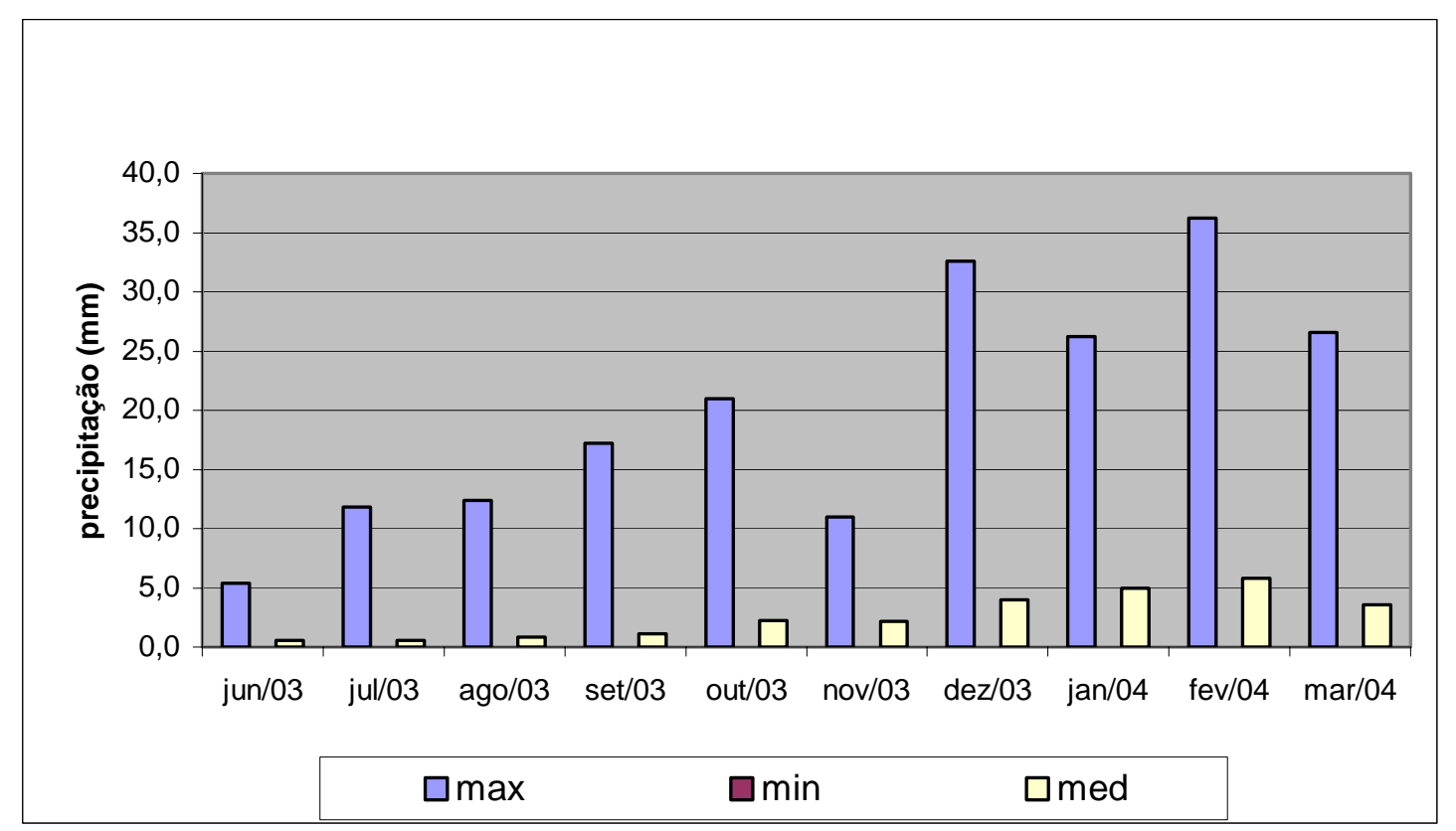

Figura 18. Valores máximos, mínimos, médios, acumulados da variável pluviometria da bacia, referentes aos períodos de junho a setembro/03 (meses secos) e de outubro/03 a março/04 (meses chuvosos).

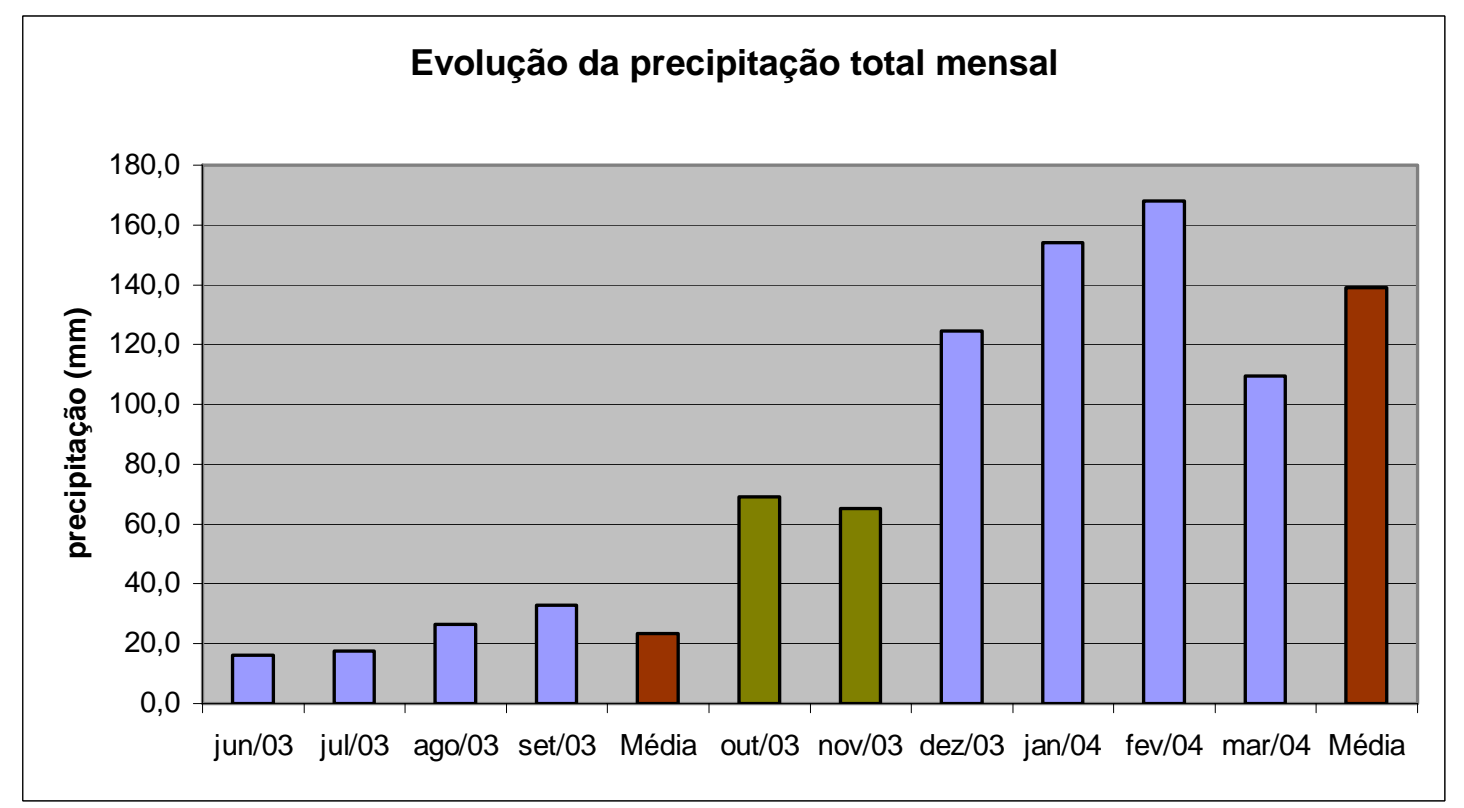

Figura 19. Valores acumulados mensais e média por período da variável pluviometria da bacia, referentes aos períodos de junho a setembro/03 (meses secos) e de outubro/03 a março/04 (meses chuvosos). 


\subsection{VAZÃO DE ENTRADA DA VÁRZEA}

$\mathrm{Na}$ Tabela 5 e na Figura 20 são apresentados os dados das vazões de entrada na várzea (GU213). Uma vez que dispúnhamos somente de dados de entrada da várzea, sem o conhecimento de vazão de fontes difusas e de saída da várzea, não foi possível fazer um balanço hídrico. Conseqüentemente, não foi possível afirmar qual a influência dessas vazões das fontes difusas. As vazões apuradas na entrada da várzea tanto no período seco quanto no chuvoso apresentam médias muito próximas, porém como pode ser observada na Figura 21, a constância da média no período seco é devido ao bombeamento regular de águas da Billings, enquanto que no período chuvoso esta média sofre influência direta pela contribuição pluviométrica.

Tabela 5. Valores máximos, mínimos, médios e desvios padrão das vazões da entrada da várzea.

\begin{tabular}{|c|c|c|c|}
\hline \multirow{2}{*}{$\begin{array}{c}\text { Meses secos/ } \\
\text { chuvosos }\end{array}$} & \multicolumn{3}{|c|}{ Vazões GU213 (m³/s) } \\
\hline & $\max$ & $\min$ & méd \\
\hline jun/03 & 4,30 & 2,42 & 4,02 \\
\hline jul/03 & 4,29 & 3,29 & 4,11 \\
\hline ago/03 & 4,23 & 3,83 & 4,14 \\
\hline set/03 & 4,62 & 3,71 & 4,51 \\
\hline Média & & & 4,20 \\
\hline Desvio Padrão & & & 0,22 \\
\hline out $/ 03$ & 4,79 & 2,35 & 4,47 \\
\hline nov/03 & 4,82 & 4,28 & 4,66 \\
\hline dez/03 & 4,88 & 4,46 & 4,72 \\
\hline jan/04 & 5,47 & 4,19 & 4,80 \\
\hline fev/04 & 5,52 & 4,62 & 4,86 \\
\hline mar/04 & 5,44 & 3,97 & 4,88 \\
\hline Média & & & 4,73 \\
\hline Desvio Padrão & & & 0,15 \\
\hline
\end{tabular}




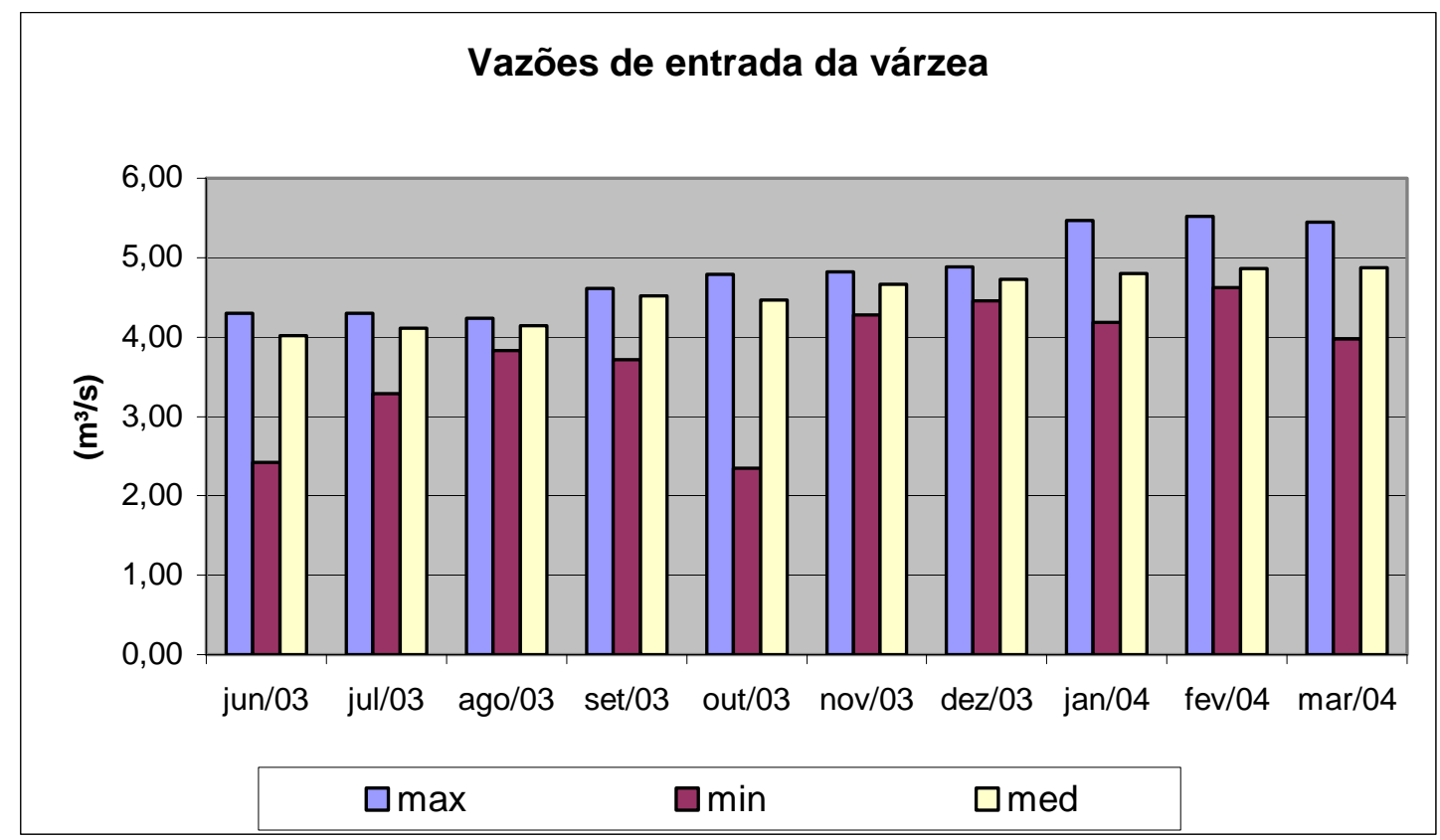

Figura 20. Valores máximos, mínimos e médios da variável vazão de entrada da várzea, referentes aos períodos de junho a setembro/03 (meses secos) e de outubro/03 a março/04 (meses chuvosos).

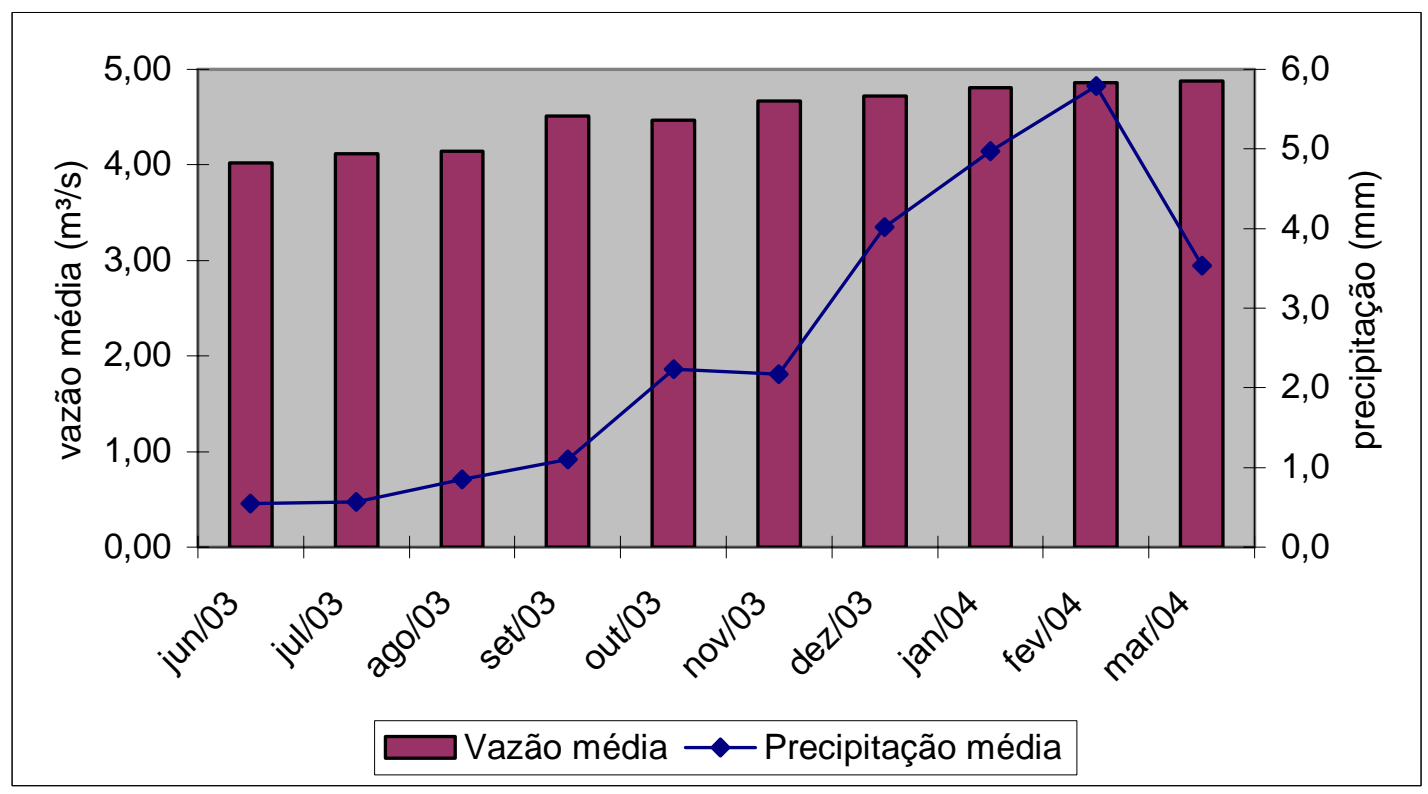

Figura 21. Valores médios das variáveis vazão e precipitação, referentes aos períodos de junho a setembro/03 (meses secos) e de outubro/03 a março/04 (meses chuvosos). 


\subsection{FÓSFORO TOTAL}

Pode-se observar nos dados da Tabela 6 ilustrados na Figura 22 que durante período seco ocorreu aumento das concentrações de fósforo total na várzea (em torno de $30 \%$ de aumento), seguindo a mesma tendência durante o período chuvoso.

Tabela 6. Valores máximos, mínimos, médios e desvios padrão da variável fósforo total da entrada e saída da várzea.

\begin{tabular}{|c|c|c|c|c|c|c|}
\hline \multirow{3}{*}{$\begin{array}{l}\text { Meses secosl } \\
\text { chuvosos }\end{array}$} & \multicolumn{3}{|c|}{ GU213 - Jaceguava } & \multicolumn{3}{|c|}{ GU107S } \\
\hline & \multicolumn{3}{|c|}{ Fósforo total (mg/L) } & \multicolumn{3}{|c|}{ Fósforo total (mg/L) } \\
\hline & $\max$ & $\min$ & méd & $\max$ & $\min$ & méd \\
\hline jun/03 & 0,10 & 0,07 & 0,09 & 0,17 & 0,10 & 0,13 \\
\hline jul/03 & 0,25 & 0,12 & 0,17 & 0,25 & 0,19 & 0,22 \\
\hline Ago/03 & 0,23 & 0,12 & 0,17 & 0,26 & 0,21 & 0,24 \\
\hline Set/03 & 0,34 & 0,12 & 0,17 & 0,23 & 0,16 & 0,19 \\
\hline Média & & & 0,15 & & & 0,19 \\
\hline Desvio Padrão & & & 0,04 & & & 0,04 \\
\hline out/03 & 0,12 & 0,10 & 0,11 & 0,17 & 0,15 & 0,16 \\
\hline Nov/03 & 0,16 & 0,10 & 0,14 & 0,26 & 0,15 & 0,19 \\
\hline Dez/03 & 0,18 & 0,16 & 0,17 & 0,24 & 0,14 & 0,17 \\
\hline Jan/04 & 0,14 & 0,12 & 0,13 & 0,21 & 0,16 & 0,19 \\
\hline Fev/04 & 0,10 & 0,05 & 0,08 & 0,28 & 0,10 & 0,15 \\
\hline Mar/04 & 0,11 & 0,07 & 0,08 & 0,12 & 0,06 & 0,09 \\
\hline Média & & & 0,12 & & & 0,16 \\
\hline Desvio Padrão & & & 0,03 & & & 0,04 \\
\hline
\end{tabular}




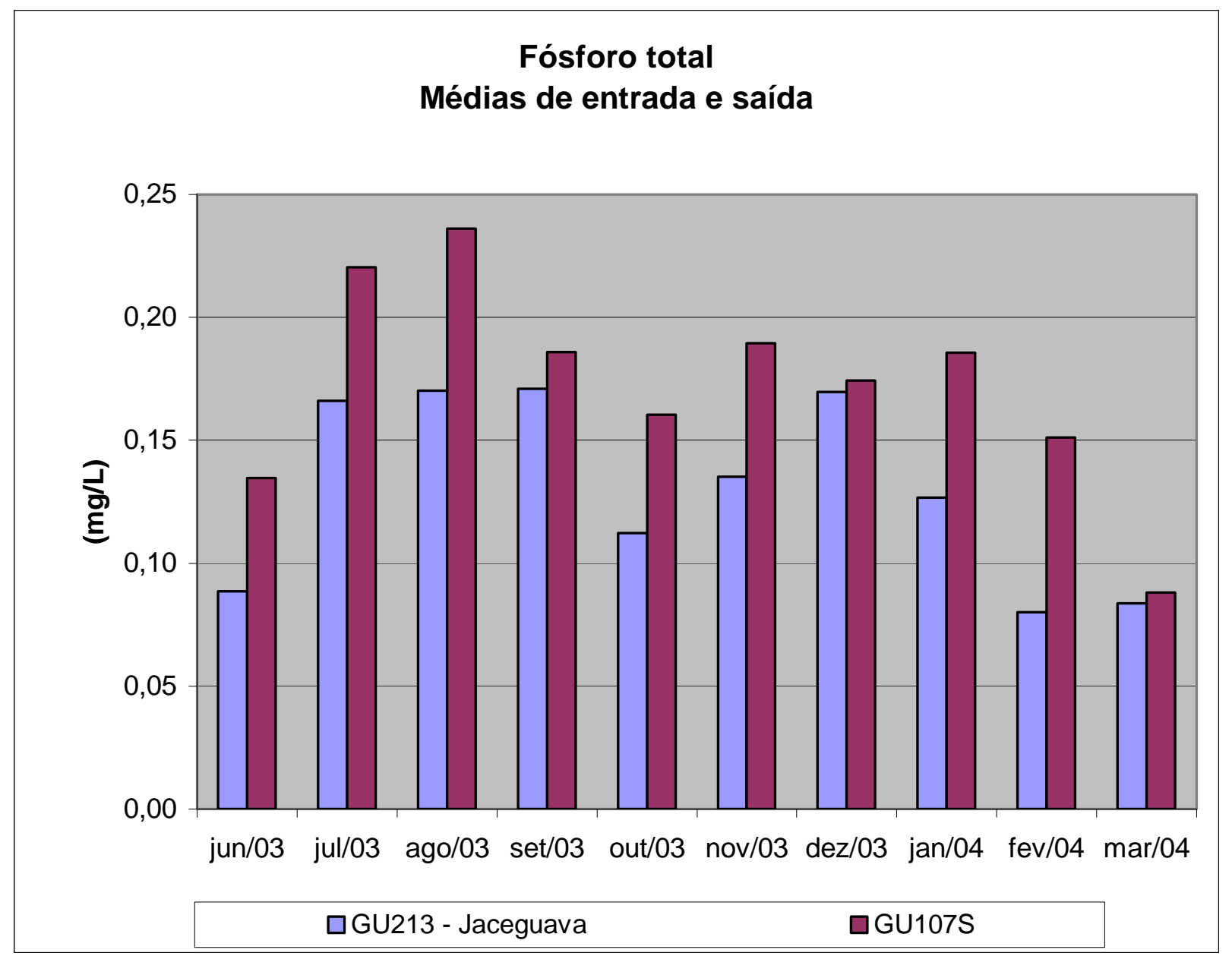

Figura 22. Valores médios da variável fósforo total da entrada (GU213) e saída (GU107) da várzea, referentes aos períodos de junho a setembro/03 (meses secos) e de outubro/03 a março/04 (meses chuvosos). 


\subsection{NITROGÊNIO TOTAL}

Na Tabela 7 e na Figura 23 foi observado no período seco um ligeiro incremento das concentrações de nitrogênio total na várzea, em torno de $20 \%$ com relação às médias.

Para o período chuvoso, foi observado um incremento de cerca de $60 \%$ nas concentrações, com relação às médias.

Tabela 7. Valores máximos, mínimos, médios e desvios padrão da variável nitrogênio total da entrada e saída da várzea.

\begin{tabular}{|c|c|c|c|c|c|c|}
\hline \multirow{2}{*}{$\begin{array}{c}\text { Meses secos/ } \\
\text { chuvosos }\end{array}$} & \multicolumn{3}{|c|}{ GU213 - Jaceguava } & \multicolumn{4}{c|}{ GU107S } \\
\cline { 2 - 7 } & \multicolumn{2}{|c|}{ Nitrogênio total (mg/L) } & \multicolumn{2}{c|}{ Nitrogênio total (mg/L) } \\
\cline { 2 - 7 } & max & Min & méd & max & min & méd \\
\hline jun/03 & 1,10 & 1,00 & 1,06 & 1,60 & 1,21 & 1,37 \\
jul/03 & 1,63 & 1,29 & 1,41 & 1,89 & 1,64 & 1,79 \\
ago/03 & 4,60 & 1,45 & 2,37 & 2,66 & 1,91 & 2,29 \\
set/03 & 1,40 & 0,98 & 1,26 & 2,04 & 1,92 & 1,97 \\
\hline Média & & & 1,53 & & & 1,85 \\
Desvio Padrão & & & 0,6 & & & 0,4 \\
\hline out/03 & 1,30 & 1,04 & 1,23 & 2,30 & 1,81 & 2,06 \\
nov/03 & 1,21 & 1,04 & 1,16 & 2,81 & 1,69 & 2,33 \\
dez/03 & 1,13 & 1,04 & 1,09 & 2,00 & 0,86 & 1,42 \\
jan/04 & 1,44 & 0,59 & 1,01 & 1,93 & 1,12 & 1,47 \\
fev/04 & 1,02 & 0,66 & 0,84 & 1,57 & 0,91 & 1,24 \\
mar/04 & 1,08 & 0,81 & 0,95 & 1,10 & 0,59 & 0,81 \\
\hline Média & & & 1,0 & & & 1,6 \\
Desvio Padrão & & & 0,14 & & & 0,55 \\
\hline
\end{tabular}




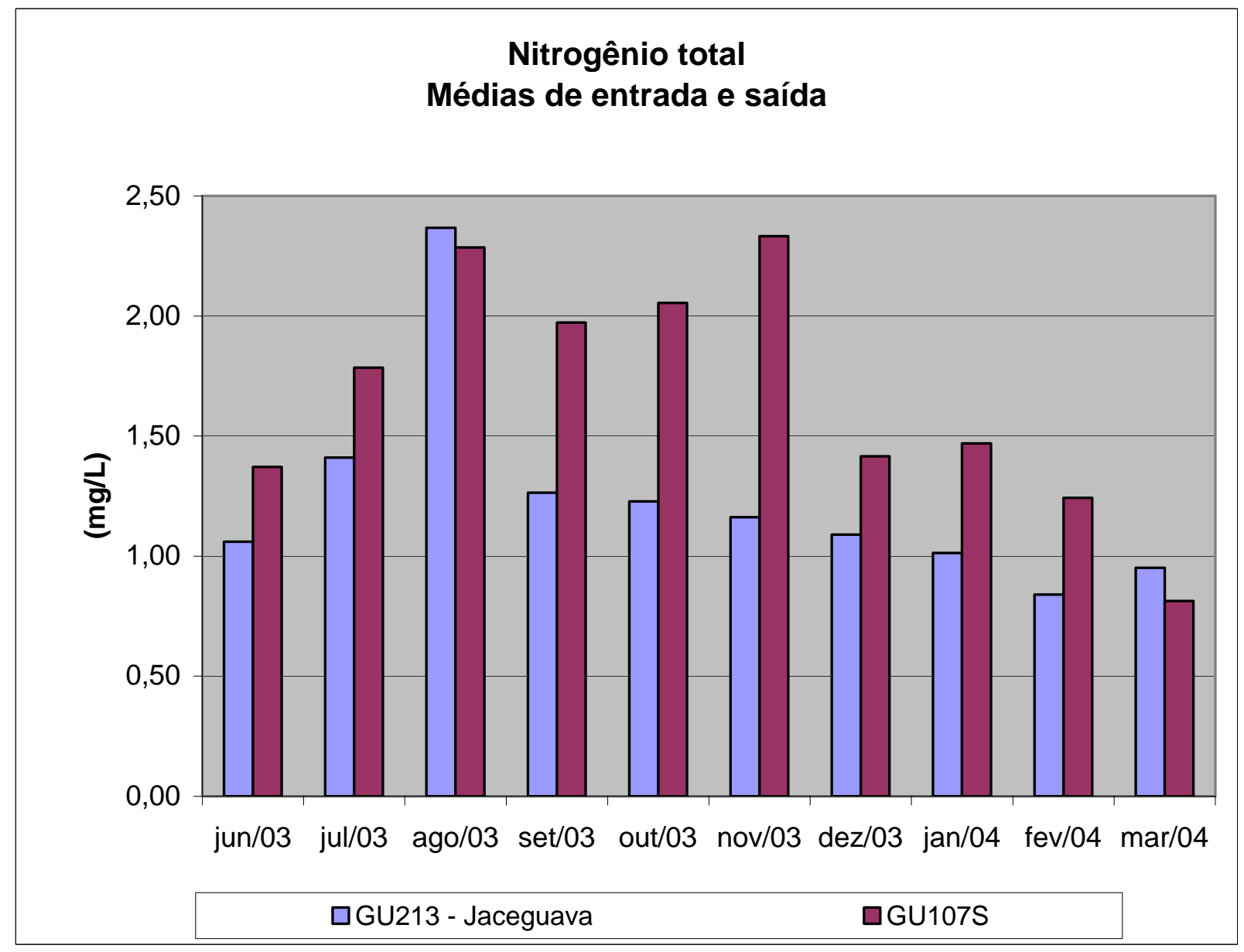

Figura 23. Valores médios da variável nitrogênio total da entrada e saída da várzea, referentes aos períodos de junho a setembro/03 (meses secos) e de outubro/03 a março/04 (meses chuvosos). 


\subsection{DEMANDA QUÍMICA DE OXIGÊNIO}

Foi verificada uma redução de cerca de $30 \%$ pela várzea, no tocante as médias, durante o período seco, já no chuvoso ocorreu, no tocante as médias do período, uma redução inferior da ordem de $20 \%$, o que pode ser verificado de acordo com os valores apresentados na Tabela 8 e na Figura 24.

Tabela 8. Valores máximos, mínimos, médios e desvios padrão da variável DQO da entrada e saída da várzea.

\begin{tabular}{|c|ccc|c|c|c|}
\hline \multirow{2}{*}{$\begin{array}{c}\text { Meses secos/ } \\
\text { chuvosos }\end{array}$} & \multicolumn{3}{|c|}{ GU213 - Jaceguava } & \multicolumn{3}{c|}{ GU107S } \\
\cline { 2 - 7 } & \multicolumn{3}{|c|}{ DQO (mg/L) } & \multicolumn{3}{c|}{ DQO (mg/L) } \\
\cline { 2 - 7 } & max & min & méd & max & min & méd \\
\hline jun/03 & 30,0 & 27,0 & 28,7 & & & \\
jul/03 & 38,0 & 29,0 & 33,6 & 17,0 & 17,0 & 17,0 \\
ago/03 & 32,0 & 27,0 & 29,3 & 26,0 & 26,0 & 26,0 \\
set/03 & 33,0 & 21,0 & 26,6 & 24,0 & 24,0 & 24,0 \\
\hline Média & & & 29,5 & & & 22,3 \\
Desvio Padrão & & & 2,9 & & & 4,7 \\
\hline out/03 & 41,0 & 25,0 & 30,3 & 25,0 & 25,0 & 25,0 \\
nov/03 & 34,0 & 25,0 & 29,5 & 30,0 & 30,0 & 30,0 \\
dez/03 & 37,0 & 35,0 & 36,0 & 30,0 & 23,0 & 25,8 \\
jan/04 & 28,0 & 10,0 & 20,3 & 34,0 & 24,0 & 27,3 \\
fev/04 & 39,0 & 19,0 & 30,3 & 23,0 & 13,0 & 16,7 \\
mar/04 & 26,0 & 21,0 & 23,6 & 18,0 & 12,0 & 15,3 \\
\hline Média & \multicolumn{7}{|c|}{28} & & & 23 \\
Desvio Padrão & & & 5,6 & & & 6,0 \\
\hline
\end{tabular}




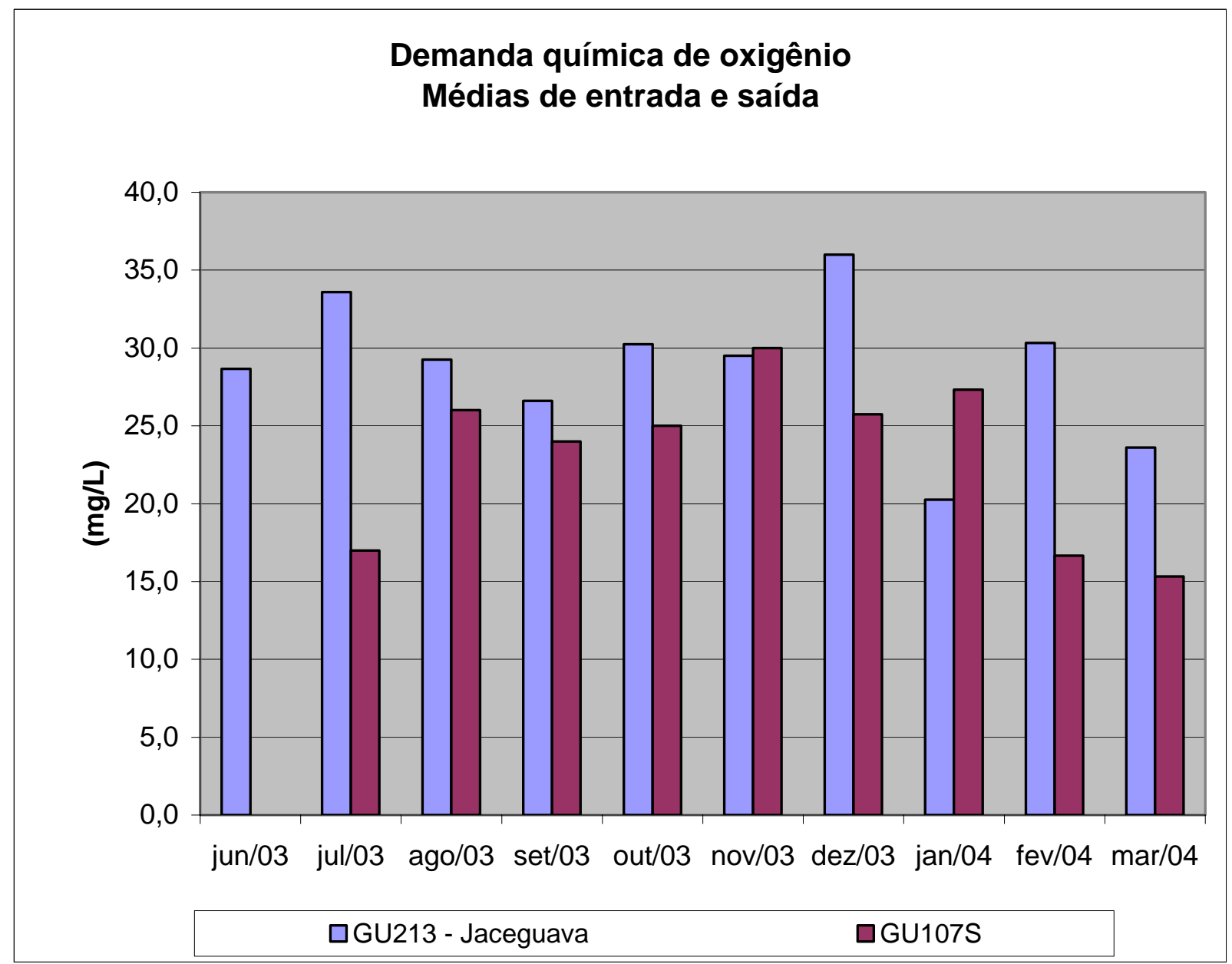

Figura 24. Valores médios da variável DQO da entrada e saída da várzea, referentes aos períodos de junho a setembro/03 (meses secos) e de outubro/03 a março/04 (meses chuvosos). 


\subsection{COR APARENTE}

Pela avaliação da Tabela 9 e da Figura 25, no período seco não foi observada diferença significativa entre as médias de cor aparente em pontos antes e depois da várzea (montante e jusante).

Ainda foi observado um pequeno abatimento de cor pela várzea (cerca de 6 unidades de cor) no período chuvoso. No entanto, acredita-se que tal pequena variação não seja significante em alterações de transparência das águas. Tipicamente, são os teores de sólidos suspensos que apresentam relevância nesse aspecto.

Tabela 9. Valores máximos, mínimos, médios e desvios padrão da variável cor da entrada e saída da várzea.

\begin{tabular}{|c|c|c|c|c|c|c|}
\hline \multirow{2}{*}{$\begin{array}{c}\text { Meses secosl } \\
\text { chuvosos }\end{array}$} & \multicolumn{3}{|c|}{ GU213 - Jaceguava } & \multicolumn{3}{c|}{ GU107S } \\
\cline { 2 - 7 } & max & min & méd & max & min & méd \\
\cline { 2 - 7 } jun/03 & 50 & 50 & 50 & 60 & 40 & 44 \\
jul/03 & 50 & 40 & 48 & 60 & 40 & 44 \\
ago/03 & 40 & 35 & 39 & 40 & 40 & 40 \\
set/03 & 40 & 40 & 40 & 50 & 40 & 42 \\
\hline Média & & & 44 & & & 43 \\
Desvio Padrão & & & 5,6 & & 40 & 4,9 \\
\hline out/03 & 60 & 40 & 45 & 50 & 40 & 44 \\
nov/03 & 60 & 40 & 50 & 50 & 40 & 44 \\
dez/03 & 60 & 60 & 60 & 50 & 40 & 44 \\
jan/04 & 80 & 40 & 50 & 50 & 40 & 42 \\
fev/04 & 60 & 40 & 50 & 50 & 40 & 40 \\
mar/04 & 40 & 40 & 40 & 40 & 40 & 43 \\
\hline Média & & & 49 & & & \\
Desvio Padrão & & & 6,6 & & & \\
\hline
\end{tabular}




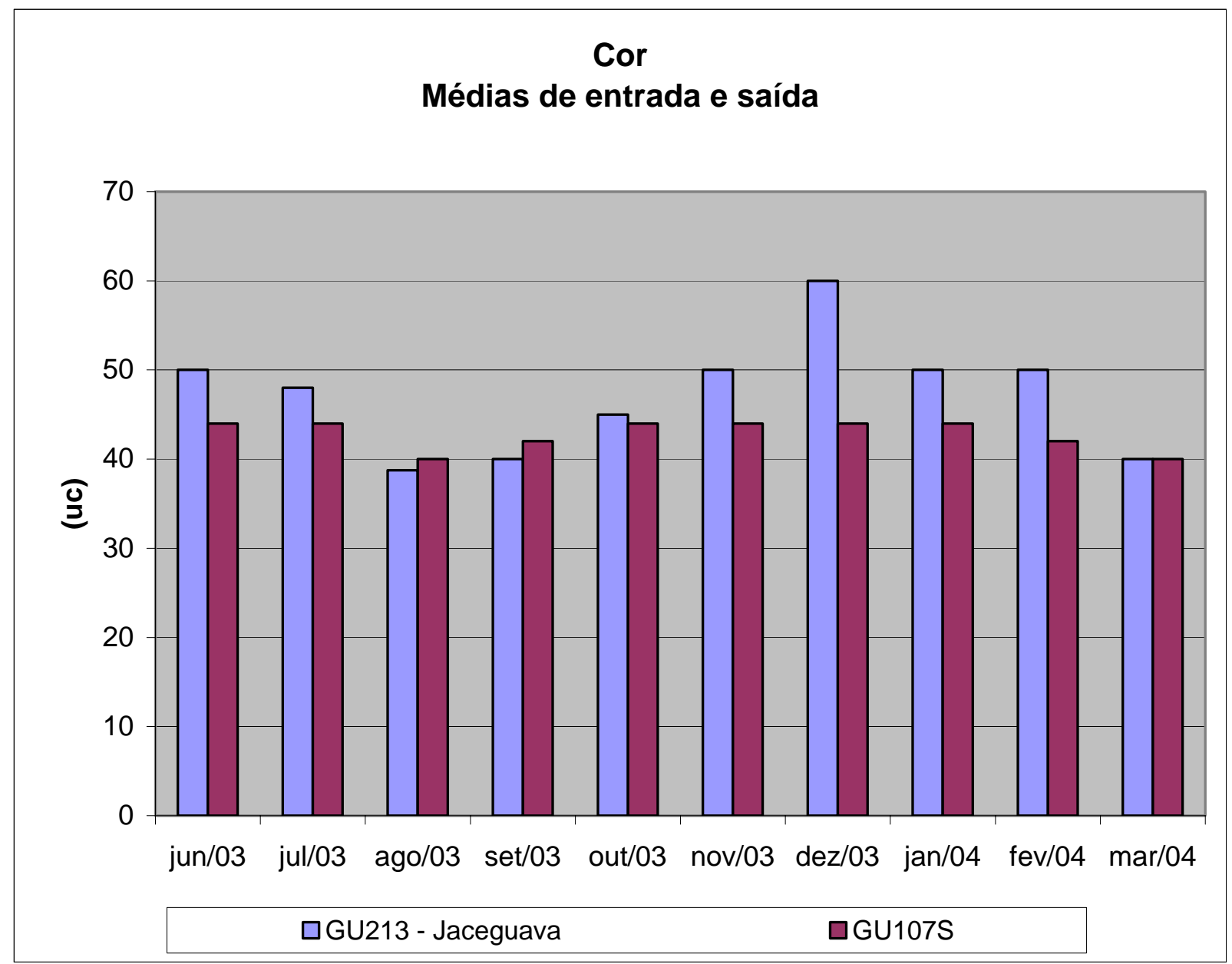

Figura 25. Valores médios da variável cor da entrada e saída da várzea, referentes aos períodos de junho a setembro/03 (meses secos) e de outubro/03 a março/04 (meses chuvosos). 


\subsection{POTENCIAL HIDROGENIÔNICO - pH}

No período seco e no chuvoso foi verificada uma diferença entre os valores médios obtidos para antes e depois da várzea, conforme pode-se observar na Tabela 10 e na Figura 26, sendo os respectivos valores do período seco 7,9 e 7,1.

Da mesma forma os valores do período chuvoso analogamente ao período seco, foram 8,0 e 7,0 para os pontos de amostragem antes e depois da várzea, respectivamente.

Tabela 10. Valores máximos, mínimos, médios e desvios padrão da variável pH da entrada e saída da várzea.

\begin{tabular}{|c|c|c|c|c|c|c|}
\hline \multirow{2}{*}{$\begin{array}{c}\text { Meses secos/ } \\
\text { chuvosos }\end{array}$} & \multicolumn{3}{|c|}{ GU213 - Jaceguava } & \multicolumn{3}{c|}{ GU107S } \\
\cline { 2 - 7 } & \multicolumn{3}{|c|}{ pH } & \multicolumn{3}{c|}{ pH } \\
\cline { 2 - 7 } jun/03 & 8,0 & 7,8 & 7,9 & 7,1 & 7,0 & 7,1 \\
jul/03 & 8,5 & 7,5 & 7,8 & 7,1 & 7,0 & 7,0 \\
ago/03 & 7,8 & 7,5 & 7,7 & 7,1 & 7,0 & 7,1 \\
set/03 & 8,6 & 7,8 & 8,0 & 7,1 & 7,0 & 7,1 \\
\hline Média & & & 7,9 & & & 7,1 \\
Desvio Padrão & & & 0,2 & & & 0,0 \\
\hline out/03 & 8,6 & 7,6 & 8,0 & 7,1 & 7,0 & 7,1 \\
nov/03 & 8,9 & 8,1 & 8,6 & 7,2 & 7,0 & 7,1 \\
dez/03 & 8,9 & 7,7 & 8,4 & 7,2 & 7,1 & 7,1 \\
jan/04 & 8,2 & 7,5 & 7,7 & 7,3 & 7,1 & 7,2 \\
fev/04 & 8,7 & 7,6 & 8,2 & 7,4 & 7,1 & 7,2 \\
mar/04 & 7,8 & 7,5 & 7,6 & 7,7 & 7,2 & 7,4 \\
\hline Média & & & 8 & & & 7 \\
Desvio Padrão & & & 0,4 & & & 0,1 \\
\hline
\end{tabular}




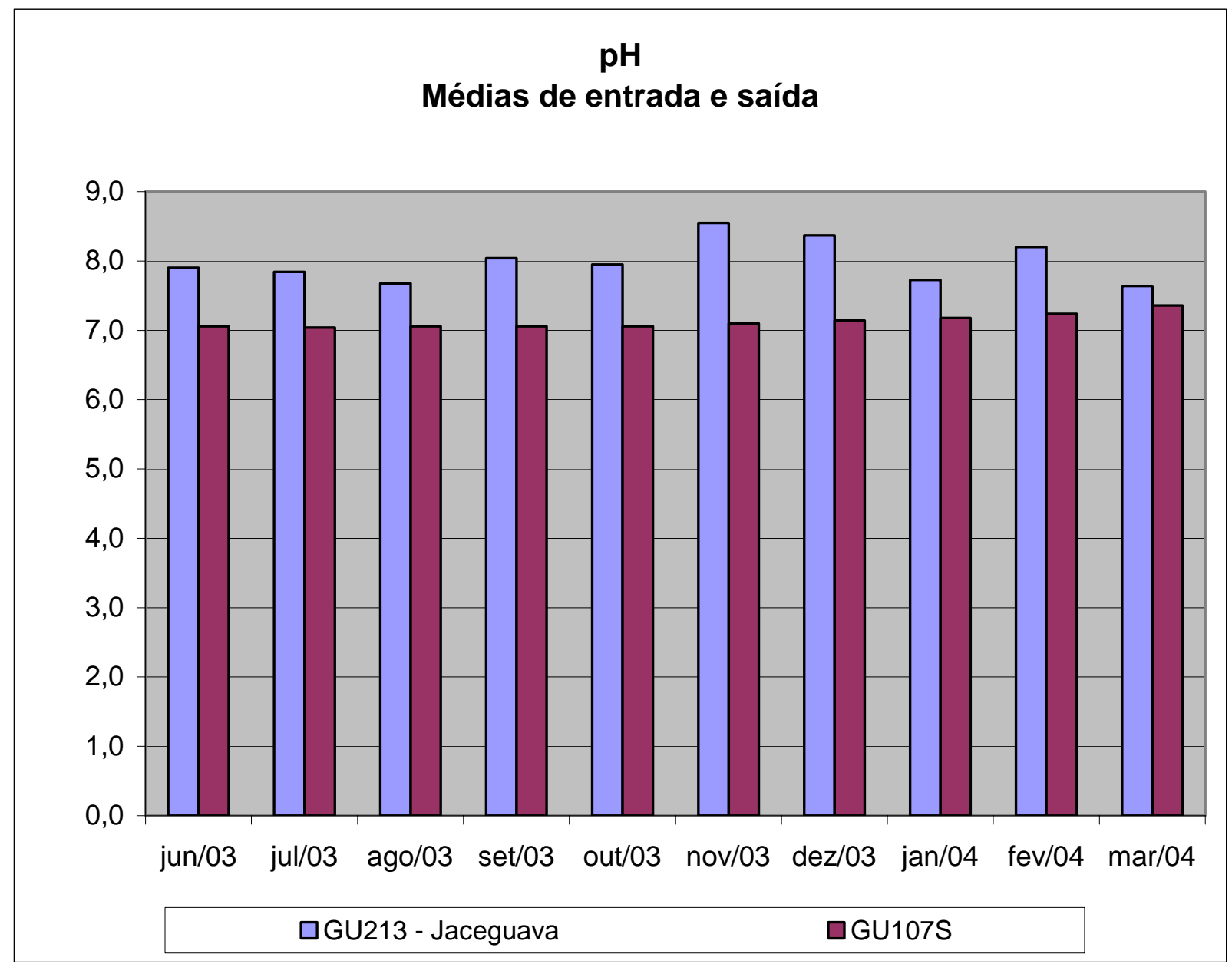

Figura 26. Valores médios da variável cor da entrada e saída da várzea, referentes aos períodos de junho a setembro/03 (meses secos) e de outubro/03 a março/04 (meses chuvosos). 


\subsection{TURBIDEZ}

Pela análise dos valores da Tabela 11 e do gráfico da Figura 27, verificou-se que durante o período seco houve um bom abatimento da turbidez média (da ordem de 30\%) pela várzea.

Já no período chuvoso foi verificada uma redução das concentrações de turbidez na várzea superior à do período seco da ordem $50 \%$.

Tabela 11. Valores máximos, mínimos, médios e desvios padrão da variável turbidez da entrada e saída da várzea.

\begin{tabular}{|c|c|c|c|c|c|c|}
\hline \multirow{3}{*}{$\begin{array}{l}\text { Meses secosl } \\
\text { chuvosos }\end{array}$} & \multirow{2}{*}{\multicolumn{3}{|c|}{ GU213 - Jaceguava }} & \multirow{2}{*}{\multicolumn{3}{|c|}{$\begin{array}{c}\text { GU107S } \\
\text { Turbidez (UNT) }\end{array}$}} \\
\hline & & & & & & \\
\hline & $\max$ & $\min$ & méd & $\max$ & $\min$ & méd \\
\hline jun/03 & 8,4 & 6,2 & 7,4 & 8,4 & 3,5 & 5,3 \\
\hline jul/03 & 7,7 & 6,8 & 7,3 & 8,4 & 3,5 & 5,3 \\
\hline ago/03 & 9,0 & 6,9 & 7,8 & 5,4 & 3,5 & 4,7 \\
\hline set/03 & 8,3 & 6,0 & 7,0 & 5,6 & 3,5 & 4,9 \\
\hline Média & & & 7,4 & & & 5,0 \\
\hline Desvio Padrão & & & 0,3 & & & 0,3 \\
\hline out/03 & 9,4 & 5,6 & 7,9 & 6,6 & 4,7 & 5,5 \\
\hline nov/03 & 13,8 & 8,0 & 11,2 & 7,5 & 5,1 & 6,0 \\
\hline dez/03 & 17,3 & 12,7 & 15,0 & 8,8 & 5,4 & 6,8 \\
\hline jan/04 & 19,7 & 7,6 & 12,7 & 8,8 & 5,6 & 7,4 \\
\hline fev/04 & 13,5 & 11,3 & 12,3 & 12,0 & 6,6 & 8,7 \\
\hline mar/04 & 22,5 & 7,4 & 12,0 & 15,0 & 7,5 & 10,4 \\
\hline Média & & & 12 & & & 7 \\
\hline Desvio Padrão & & & 2,3 & & & 1,8 \\
\hline
\end{tabular}




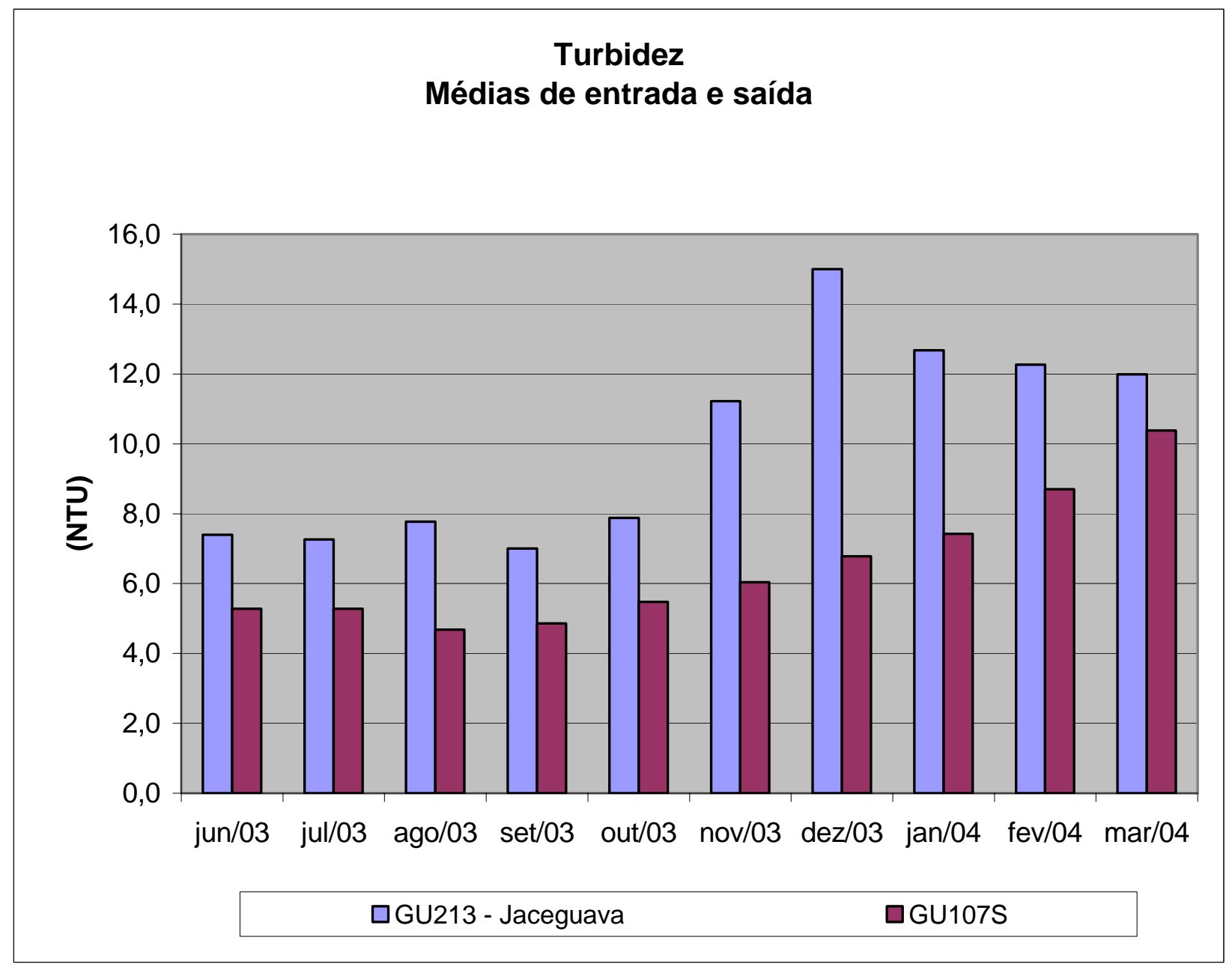

Figura 27. Valores médios da variável turbidez da entrada e saída da várzea, referentes aos períodos de junho a setembro/03 (meses secos) e de outubro/03 a março/04 (meses chuvosos). 


\subsection{COLIFORMES TOTAIS}

Verificou-se pelos valores expressos na Tabela 12 e na Figura 28 que, em termos de valores médios, ocorreu um aumento na saída da várzea da concentração de coliformes totais no período seco (em torno de 225\%) e no período chuvoso (em torno de $320 \%$ ) em relação as médias de entrada da várzea.

Tabela 12. Valores máximos, mínimos, médios e desvios padrão da variável coliformes totais da entrada e saída da várzea.

\begin{tabular}{|c|c|c|c|c|c|c|}
\hline \multirow{3}{*}{$\begin{array}{l}\text { Meses secosl } \\
\text { chuvosos }\end{array}$} & \multicolumn{3}{|c|}{ GU213 - Jaceguava } & \multicolumn{3}{|c|}{ GU107S } \\
\hline & \multicolumn{3}{|c|}{ Coliformes totais (NMP/100 mL) } & \multicolumn{3}{|c|}{ Coliformes totais (NMP/100 mL) } \\
\hline & $\max$ & $\min$ & méd & $\max$ & $\min$ & méd \\
\hline jun/03 & 12960 & 4100 & 8553 & 92080 & 38730 & 62835 \\
\hline jul/03 & 178020 & 5360 & 59978 & 111990 & 46110 & 85565 \\
\hline ago/03 & 155310 & 13170 & 74410 & 155310 & 64880 & 110727 \\
\hline set/03 & 92080 & 11870 & 53408 & 241920 & 86640 & 188460 \\
\hline Média & & & 49087 & & & 111897 \\
\hline Desvio Padrão & & & 28411 & & & 54662 \\
\hline out/03 & 38730 & 12997 & 26518 & 241920 & 57940 & 149930 \\
\hline nov/03 & 38800 & 7270 & 20574 & 241920 & 98040 & 159158 \\
\hline dez/03 & 51720 & 24192 & 36154 & 198630 & 75550 & 123640 \\
\hline jan/04 & 241920 & 11530 & 106683 & 241920 & 98040 & 180810 \\
\hline fev/04 & 69700 & 23590 & 39807 & 218700 & 72700 & 153015 \\
\hline mar/04 & 41000 & 18720 & 25951 & 92080 & 24192 & 49791 \\
\hline Média & & & 42614 & & & 136057 \\
\hline Desvio Padrão & & & 32177 & & & 46071 \\
\hline
\end{tabular}




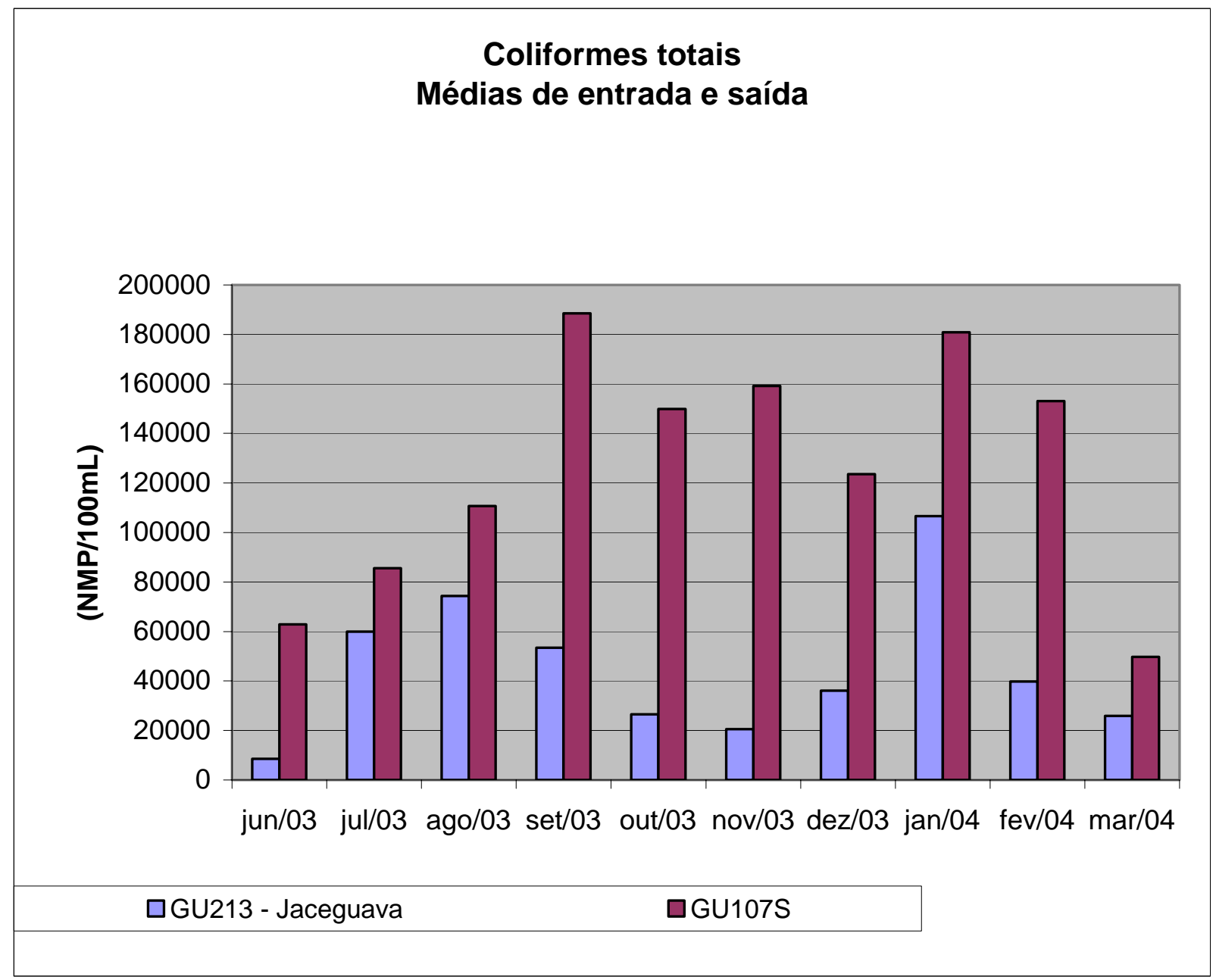

Figura 28. Valores médios da variável coliformes totais da entrada e saída da várzea, referentes aos períodos de junho a setembro/03 (meses secos) e de outubro/03 a março/04 (meses chuvosos). 


\subsection{COLIFORMES FECAIS}

Na Tabela 13 e na Figura 29 os valores evidenciam que tanto no período seco quanto no chuvoso, ocorreu um incremento em termos de valores médios, da ordem de $350 \%$ e da ordem de $170 \%$, respectivamente, entre a entrada e a saída da várzea.

Tabela 13. Valores máximos, mínimos, médios e desvios padrão da variável coliformes fecais da entrada e saída da várzea.

\begin{tabular}{|c|ccc|c|c|c|}
\hline \multirow{2}{*}{$\begin{array}{c}\text { Meses secos/ } \\
\text { chuvosos }\end{array}$} & \multicolumn{3}{|c|}{ GU213 - Jaceguava } & \multicolumn{4}{c|}{ GU107S } \\
\cline { 2 - 7 } & \multicolumn{2}{|c|}{ Coliformes fecais (NMP/100 mL) } & \multicolumn{3}{c|}{ Coliformes fecais (NMP/100 mL) } \\
\cline { 2 - 7 } & max & min & méd & max & min & méd \\
\hline jun/03 & 2430 & 1000 & 1477 & 64440 & 4190 & 21203 \\
jul/03 & 6300 & 310 & 2262 & 10390 & 4130 & 7585 \\
ago/03 & 17250 & 1080 & 7230 & 13740 & 6770 & 9947 \\
set/03 & 7590 & 135 & 3493 & 173290 & 7710 & 49534 \\
\hline Média & & & 3615 & & & 22067 \\
Desvio Padrão & & & 2549 & & 17250 & 9320 \\
\hline out/03 & 2851 & 100 & 1473 & 1754 & 13285 \\
nov/03 & 3130 & 74 & 1754 & 104620 & 13130 & 44093 \\
dez/03 & 4570 & 933 & 2522 & 28510 & 12910 & 17524 \\
jan/04 & 141140 & 860 & 49515 & 129970 & 20140 & 55680 \\
fev/04 & 1000 & 860 & 933 & 17500 & 8130 & 14605 \\
mar/04 & 4500 & 199 & 1780 & 20980 & 5748 & 12976 \\
\hline Média & & & 9663 & & & 26360 \\
Desvio Padrão & & & 19530 & & 18657 \\
\hline
\end{tabular}

Esses elevados incrementos nas concentrações de coliformes podem estar relacionados a possível contaminação da várzea por esgoto de origem sanitária oriundo de fontes difusas. 
Essa observação contribui para explicar os incrementos observados anteriormente nos níveis de Nitrogênio total e Fósforo total, entre a entrada e a saída da várzea.

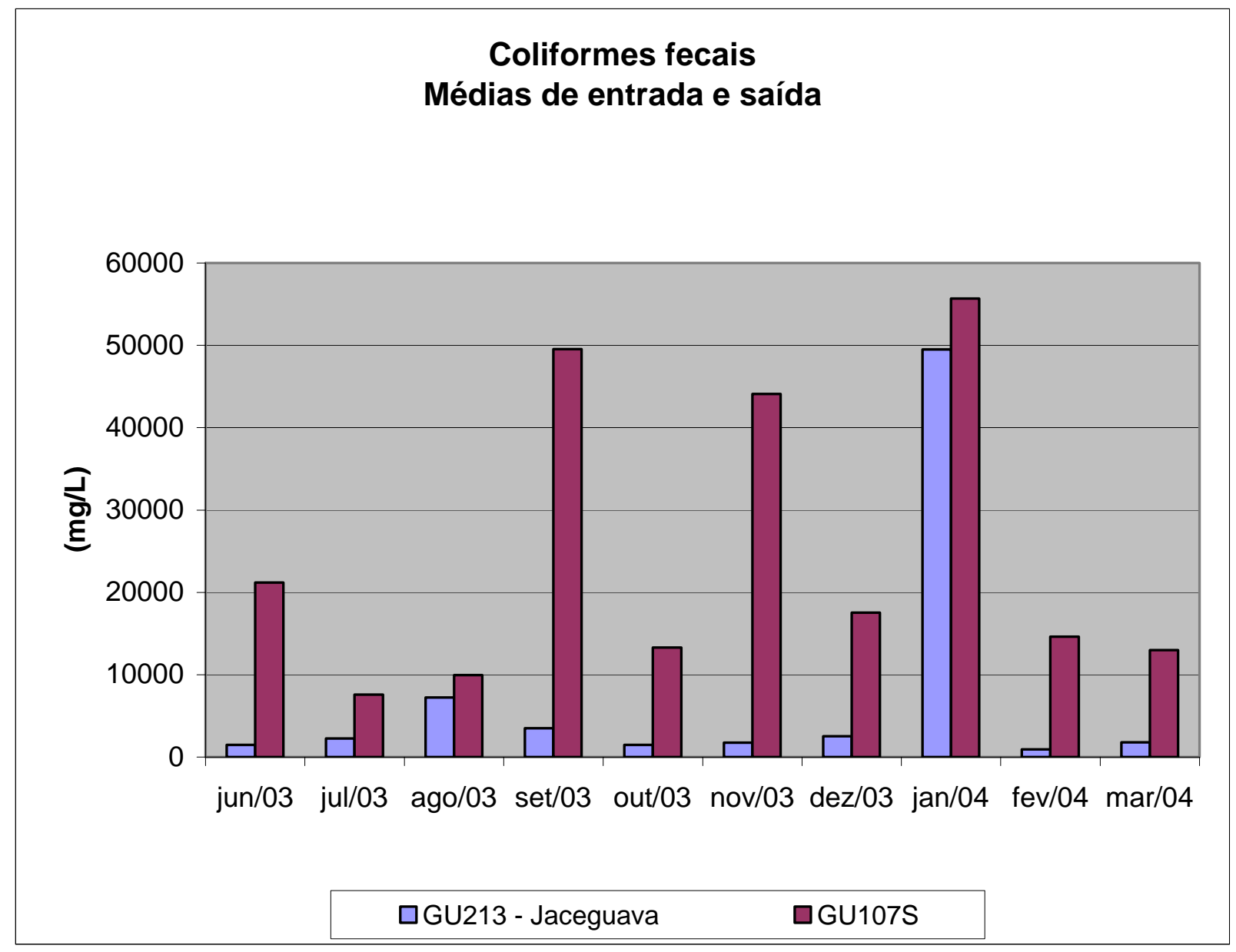

Figura 29. Valores médios da variável coliformes fecais da entrada e saída da várzea, referentes aos períodos de junho a setembro/03 (meses secos) e de outubro/03 a março/04 (meses chuvosos). 


\subsection{ALGAS CIANOFÍCEAS}

De acordo com a análise dos valores expressos na Tabela $14 \mathrm{e}$ ilustrados na Figura 30, nos períodos seco e chuvoso, ocorreram abatimentos significativos nas concentrações desses microorganismos, correspondendo à cerca de $64 \%$ e 58\% respectivamente, entre a entrada e a saída da várzea.

Tabela 14. Valores máximos, mínimos, médios e desvios padrão da variável algas cianofíceas da entrada e saída da várzea.

\begin{tabular}{|c|ccc|ccc|}
\hline \multirow{2}{*}{$\begin{array}{c}\text { Meses secos/ } \\
\text { chuvosos }\end{array}$} & \multicolumn{3}{|c|}{ GU213 - Jaceguava } & \multicolumn{3}{c|}{ GU107S } \\
\cline { 2 - 7 } & \multicolumn{2}{|c|}{ Cianofíceas (células/mL) } & \multicolumn{3}{c|}{ Cianofíceas (células/mL) } \\
\cline { 2 - 7 } & max & min & méd & max & min & méd \\
\hline Jun/03 & 237621 & 187593 & 216574 & 49266 & 33242 & 40959 \\
Jul/03 & 1030057 & 203268 & 533884 & 158076 & 74121 & 125447 \\
ago/03 & 735038 & 143229 & 343825 & 146763 & 118445 & 128662 \\
Set/03 & 260354 & 147019 & 192089 & 167748 & 127596 & 140943 \\
\hline Média & & & 321593 & & & 109003 \\
Desvio Padrão & & & 156378 & & & 45851 \\
\hline Out/03 & 287130 & 172726 & 221372 & 143865 & 143865 & 143865 \\
nov/03 & 846601 & 339710 & 586340 & 550533 & 450644 & 496570 \\
Dez/03 & 1336425 & 900913 & 1159229 & 616892 & 47728 & 287462 \\
Jan/04 & 551506 & 257660 & 344750 & 396279 & 98850 & 218854 \\
Fev/04 & 431386 & 185209 & 348478 & 102015 & 48614 & 74765 \\
mar/04 & 571657 & 190325 & 322990 & 99713 & 25125 & 47644 \\
\hline Média & \multicolumn{7}{|c|}{497193} & & & 211527 \\
Desvio Padrão & & & 345838 & & & 165656 \\
\hline
\end{tabular}




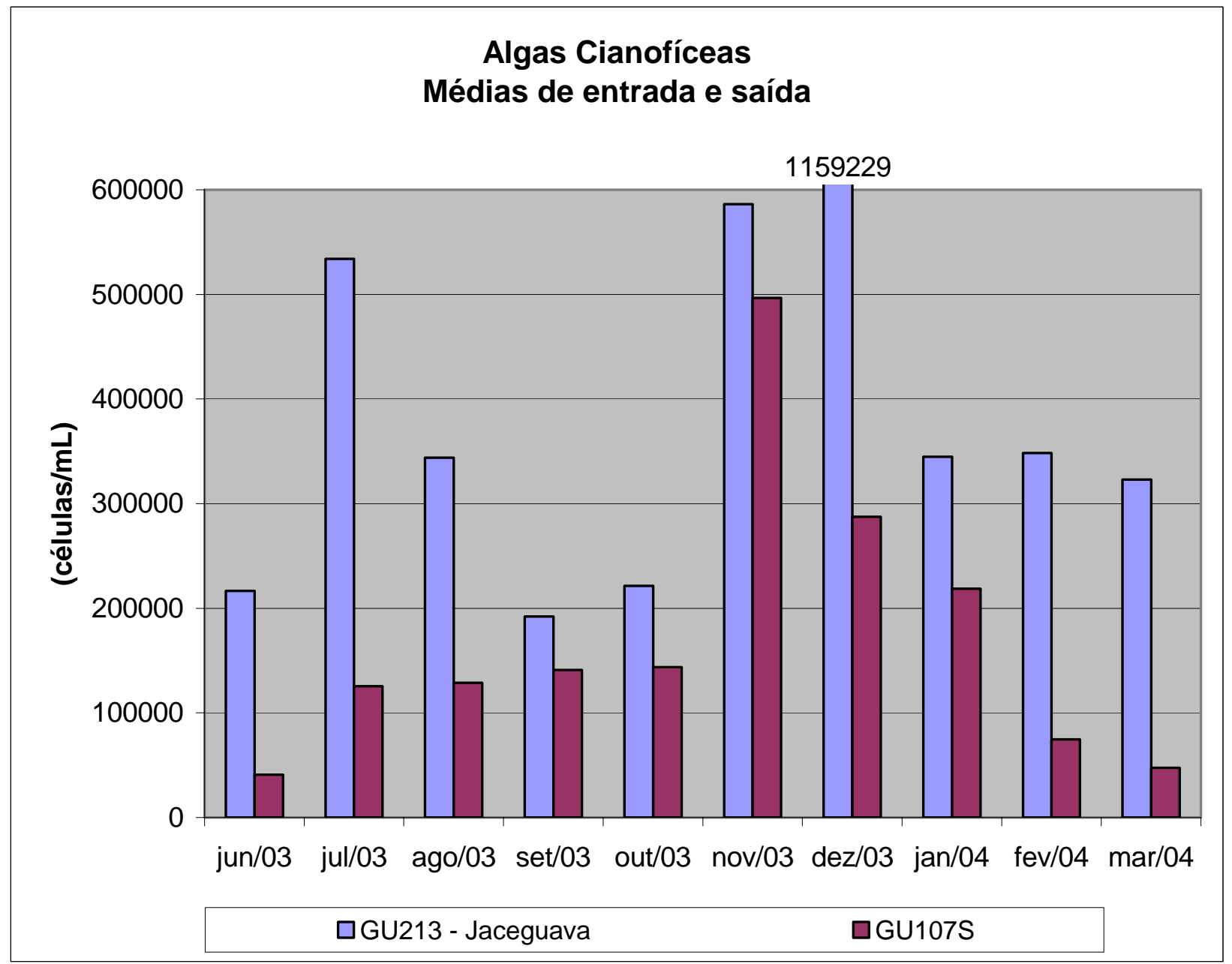

Figura 30. Valores médios da variável algas cianofíceas da entrada e saída da várzea, referentes aos períodos de junho a setembro/03 (meses secos) e de outubro/03 a março/04 (meses chuvosos). 


\subsection{MICROCISTINA}

A ocorrência de abatimentos significativos nas concentrações dessa toxina, em ambos períodos (seco e chuvoso), correspondendo à cerca de $55 \%$ e $80 \%$, respectivamente, entre a entrada e a saída da várzea, pode ser verificado na Tabela 15 e na Figura 31.

Tabela 15. Valores máximos, mínimos, médios e desvios padrão da variável microcistina da entrada e saída da várzea.

\begin{tabular}{|c|c|c|c|c|c|c|}
\hline \multirow{3}{*}{$\begin{array}{c}\text { Meses secos/ } \\
\text { chuvosos }\end{array}$} & \multicolumn{3}{|c|}{ GU213 - Jaceguava } & \multicolumn{3}{|c|}{ GU107S } \\
\hline & \multicolumn{3}{|c|}{ Microcistina $(\mu \mathrm{g} / \mathrm{L})$} & \multicolumn{3}{|c|}{ Microcistina ( $\mu \mathrm{g} / \mathrm{L})$} \\
\hline & $\max$ & $\min$ & méd & $\max$ & $\min$ & méd \\
\hline jun/03 & 0,64 & 0,00 & 0,41 & 0,23 & 0,17 & 0,20 \\
\hline jul/03 & 0,69 & 0,31 & 0,53 & 0,30 & 0,19 & 0,24 \\
\hline ago/03 & 0,36 & 0,19 & 0,27 & 0,24 & 0,24 & 0,24 \\
\hline set/03 & 0,40 & 0,31 & 0,35 & 0,00 & 0,00 & 0,00 \\
\hline Média & & & 0,39 & & & 0,17 \\
\hline Desvio Padrão & & & 0,11 & & & 0,11 \\
\hline out/03 & 2,13 & 0,50 & 1,22 & & & \\
\hline nov/03 & 24,00 & 1,62 & 9,01 & 1,53 & 0,60 & 1,21 \\
\hline dez/03 & 9,04 & 3,98 & 6,90 & 1,39 & 0,42 & 0,92 \\
\hline jan/04 & 3,05 & 1,47 & 2,06 & 1,34 & 0,49 & 0,93 \\
\hline fev/04 & 1,25 & 0,94 & 1,13 & 0,52 & 0,20 & 0,38 \\
\hline mar/04 & 0,92 & 0,26 & 0,51 & 0,61 & 0,21 & 0,45 \\
\hline Média & & & 3,47 & & & 0,78 \\
\hline Desvio Padrão & & & 3,57 & & & 0,35 \\
\hline
\end{tabular}




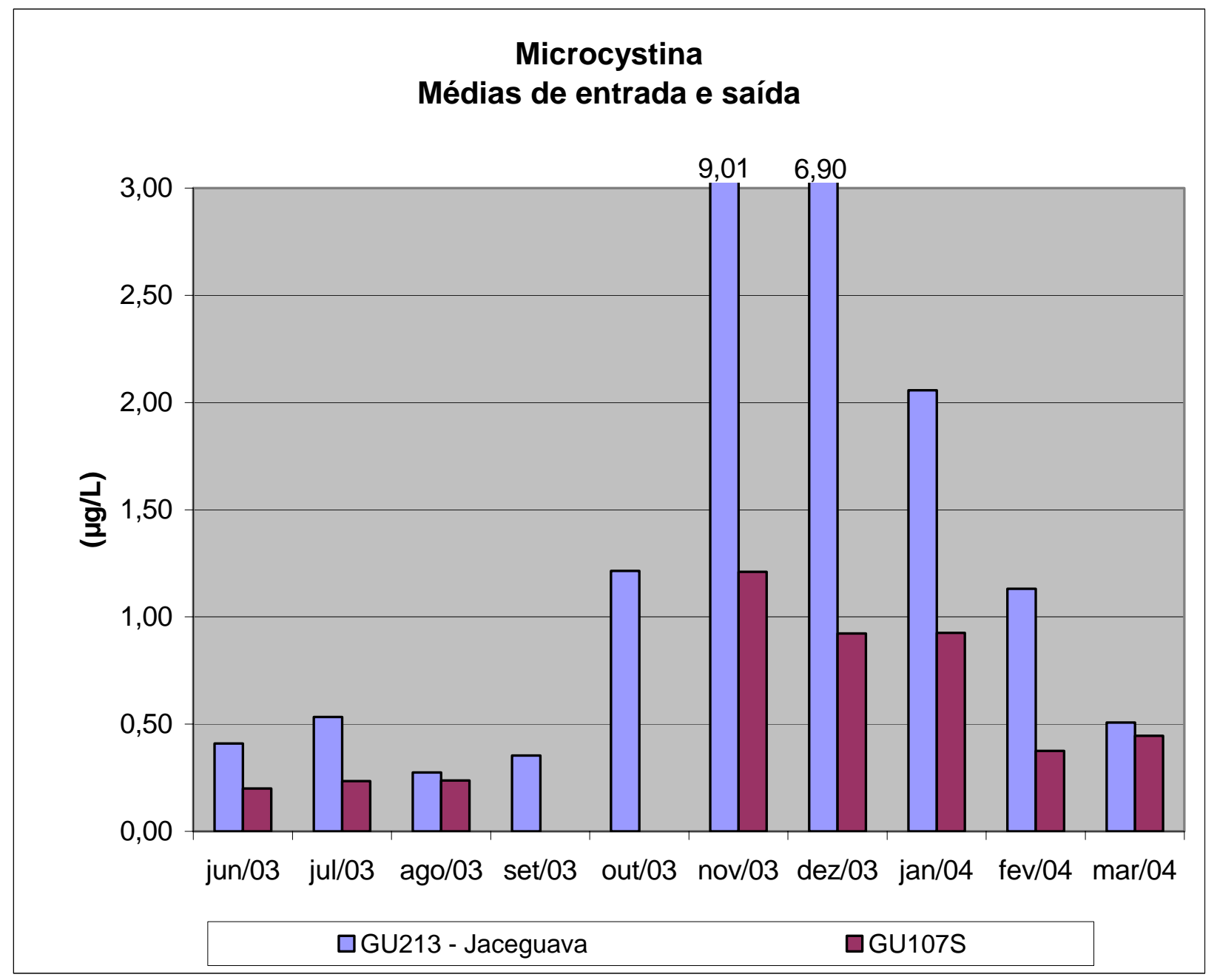

Figura 31. Valores médios da variável microcistina da entrada e saída da várzea, referentes aos períodos de junho a setembro/03 (meses secos) e de outubro/03 a março/04 (meses chuvosos). 


\section{CONCLUSÕES}

- A várzea mostrou relativamente eficiente no tocante à melhoria de algumas variáveis (DQO, cor, turbidez, algas cianofíceas e microcistina), apresentando redução dos valores de saída em comparação aos valores de entrada.

- Os resultados de fósforo total, nitrogênio total e coliformes, nos permitem afirmar que houve contribuição significativa de fontes difusas na várzea, nos períodos seco e chuvoso, uma vez que as concentrações dessas variáveis sofreram incrementos desde a entrada até a saída da várzea.

- Os aumentos das concentrações de fósforo total e nitrogênio total durante os períodos estudados devem ser parcialmente originados a partir da deficiência de afastamento de efluentes sanitários oriundos de ocupações irregulares na região. Porém os incrementos destas concentrações durante o período chuvoso podem ser decorrentes da carga difusa proveniente das chuvas que neste período lavam os campos utilizados para a agricultura, o que não ocorre no período seco pois este é marcado por baixa pluviosidade.

- Quanto ao variável coliformes totais, o incremento durante o período chuvoso pode também ser atribuído a carga difusa oriunda das chuvas.

- Já em relação a variável coliformes fecais foram verificadas na saĺda da várzea concentrações superiores no período seco em relação ao chuvoso, o que reforça a tese de deficiência do sistema de coleta e afastamento de efluentes sanitários, uma vez que os períodos de estiagem exercem menor influência quanto ao potencial de diluição da concentração de compostos poluentes e contaminantes, ou seja, provavelmente a 
contribuição à várzea de coliformes fecais seja regular ao longo dos períodos seco e chuvoso, porém a ação das chuvas e as conseqüentes cheias dos corpos d'água exercem um papel significativo como diluentes deste variável.

- Tipicamente o pH passa de 8,0 para 7,0 entre a entrada e a saída da várzea. A diminuição de aproximadamente 1 log da variável pH nos períodos seco e chuvoso pode ser conseqüência da possível formação de ácido carbônico, originado pela combinação de gás carbônico (proveniente da degradação de matéria orgânica, tipicamente abundante em áreas alagadas) com água.

- A cor aparente da água analisada não demonstrou durante ambos períodos (seco e chuvoso) nenhuma alteração significativa.

- A remoção de turbidez que ocorreu em todos os períodos estudados, pode ser explicada pela capacidade destes sistemas quanto ao amortecimento das águas de afluência que elevam as taxas de sedimentação de partículas em suspensão. Ainda há a possibilidade da retenção de partículas por aderência ao sistema radicular de macrófitas.

Durante o período chuvoso foi verificada uma remoção superior a do período seco. Possivelmente a velocidade de escoamento em áreas alagadas durante o período chuvoso é maior que a do período seco, o que levaria a taxas de sedimentação menores. Porém a dinâmica de crescimento das plantas no período chuvoso deve atingir seu auge por corresponder às estações da primavera e verão, o que reforça a tese de retenção de partículas por aderência ao sistema radicular das plantas da várzea.

- $\quad$ A redução de DQO promovida pela várzea deve ser decorrente da grande capacidade biótica das áreas alagadas em degradar matéria orgânica, seja pela ação de microorganismos, seja por adsorção radicular. 
- Pôde-se verificar reduções significativas das concentrações de células de algas cianofíceas em ambos os períodos, a diminuição dessas concentrações deve estar associada a alguns fatores típicos das áreas alagadas tais como o sombreamento proporcionado pela vegetação da várzea, uma vez que a intensidade luminosa interfere diretamente sobre a atividade dos organismos, especialmente sobre a reprodução, alterando a densidade destes organismos na água.

Ainda outro fator é citado por Cooper et al. (1996) apud Elias (2003) onde referencia que a chave dos processos de redução de microorganismos e substâncias adsorvidas pelo sistema radicular se dá pela morte natural, oxidação química, fotólise, predação e exposição a antibióticos secretados pelas raízes.

Fatores hidrodinâmicos como os movimentos internos e taxa de renovação da água, também são importantes, pois podem influenciar aspectos como a transparência d'água ou provocar turbulências típicas de sistemas lóticos.

- A redução de microcistina verificada na várzea, também pode ser referida aos mesmos mecanismos da redução das densidades das algas. 


\section{RECOMENDAÇÕES}

\subsection{CONTINUIDADE DE ESTUDOS}

- O aprofundamento dos estudos de desempenho da várzea depende da implantação de uma rede de monitoramento qualitativo e quantitativo de contribuições difusas que proporcionará a realização de balanços de massa.

- Para que os problemas provenientes das substâncias originárias a partir de fontes biogênicas em águas de abastecimento possam ser solucionados ou, pelo menos, minimizados, é fundamental que os mesmos sejam estudados de modo a permitir que as suas causas possam ser identificadas e, conseqüentemente, hajam condições de serem definidas as melhores alternativas técnicas para a sua solução.

\subsection{INSTITUCIONAIS}

- A implantação de rede coletora de esgotos sanitários nas áreas não atendidas por este serviço deve contribuir significativamente quanto ao aumento de desempenho da várzea.

- A coibição do aumento de ocupações irregulares na bacia do ribeirão Parelheiros deve ser um fator de primeira ordem de preocupação das instituições competentes a fiscalização de uso e ocupação do solo. 


\section{BIBLIOGRAFIA}

Agudo, E. G. Apostila da disciplina "Fundamentos químicos de saneamento" do curso de pós-graduação em Saneamento Ambiental da Universidade Mackenzie, 1990.

AMERICAN WATER WORKS ASSOCIATION RESEARCH FOUNDATION. identification and treatment of taste and odors in drinking water. Denver, AWWA, December, p.292, 1987.

Andrade, A.S.A., Filho. S.F.S., Fernandes, A.N., Kairala, A.M., Aplicação de Carvão Ativado em Pó (CAP) na Remoção de Gosto e Odor em Águas de Abastecimento. IX Simpósio Luso Brasileiro de Engenharia Sanitária. Porto Seguro, Bahia, 2000.

APHA - AMERICAN PUBLIC HEALTH ASSOCIATION; AWWA - AMERICAN WATER WORKS ASSOCIATION \& WEF - WATER ENVIRONMENT FEDERATION. 1992. Standard methods for the examination of water and wastewater. Washington, American Public Health Association, 18th ed., pp. 10-1 a 10-17.

Beyruth, Z; Sant'anna, C.L.; Azevedo, M. T.P.; Carvalho, M.C.; Pereira, H.A.S.L. Toxic algae in freshwaters of São Paulo State, p. 53-64, IN: Cordeiro-Marino et al. Ed. - Algae and environment: a general approach. S. Paulo, Soc. Bras. Ficologia/CETESB, 1992. 131p.

Branco,S.M. Hidrobiologia aplicada à engenharia sanitária. S. Paulo, CETESB, 1986. 616p.

Capobianco, J.P.R. Billings 2000 : ameaças e perspectivas para o maior reservatório de água da região metropolitana de São Paulo : relatório do diagnóstico sócio ambiental participativo da bacia hidrográfica da Billings no período 1989-99 / João Paulo Ribeiro Capobianco, Marussia Whately. São Paulo : Instituto Sócio ambiental, 2002.

Carmichael, W.W. The toxins of cyanobacteria. Scientific American, January 1994.

Carvalho, M.C. Fitoplâncton: características gerais e metodologias. aspectos sanitários e ecológicos. São Paulo, SP, 13 p. Apostila de curso. Faculdade de Saúde Pública . Universidade de São Paulo. 2003.

CETESB. Relatório de qualidade de água para consumo humano no Estado de São Paulo. São Paulo, SP, CETESB, Relatório Técnico, 69p. 1991 . 
Chorus, I. \& Bartram, J. (Editors). Toxic cyanobacteria in water: a guide to their public health consequences, monitoring and management. E. Who. \& F. Spom, p.416, 1999.

CONSÓRCIO HIDROPLAN. Plano integrado de aproveitamento e controle dos recursos hídricos das Bacias Alto Tietê, Piracicaba e Baixada Santista. 6 V. São Paulo : Hidroplan, dez. 1995.

Cowardin, L. M.; Carter, F. C. \& Laroe, E. T. Classification of Wetlands and deepwater habitats of the United States. US Fish \& Wildlife Service Pub. FWS/OBS-79/31. Washington, DC, p.103, 1979.

Elias, J.M. Análise da eficiência global do sistema de "wetlands" construído na estação de tratamento água para abastecimento público do município de Analândia. 2003, 206 f., Dissertação de mestrado - Universidade Estadual Paulista, Rio Claro, SP.

Esteves, F.A. Fundamentos de limnologia, Rio de Janeiro: Intercência, 1988. $575 \mathrm{p}$.

GEOTEC. Plano de gerenciamento integrado do sistema produtor Taquacetuba - Guarapiranga - Várzea de Parelheiros. Relatório 02. São Paulo : Geotec, jan. 2001.

Harbel, R., Perther, R., Laber, J. Wetland Systems for Water Pollution Control. Wat Sci. Techn. 35 Proceeding of the IAWQ. 5 rd International Conference on the Use of C W in Water Pollution Control (1996) (ed. COOPER, P. - 1997) - Vienna, Austria.

Hatano, K., Tretin, C.C., House, C.H., Wollum, A.G. Microbial population and decomposition activity in three subsurface flow constructed wetlands. In: MOSHIRI, G.A. Constructed wetlands for water improvement. Ed. Lewis Publishers, 1993.

Hook, D. D. Wetlands: history, CURRENT STATUS, AND FUTURE. Environ. Toxicol. Chem. 12: 2157-2166, 1993

Kadlec, R. H. \& Knight, R. L. Treatment Wetlands. CRC Press, Boca Raton, Fl. 893, 1996.

Lamparelli, M.C. Macrófitas aquáticas como bioindicadores. Apostila do curso Diagnóstico de ecossistemas aquáticos. Faculdade de Saúde Pública de São Paulo. Cap VIII, 2003.

Lorenzi, H. 2000. Plantas Daninhas do Brasil terrestres, aquáticas, parasitas e tóxicas $3^{a}$ ed. Instituto Plantarum de Estudos da Flora, Nova Odessa, SP. 608 p. 
Lugo, A. E., Brown, S. \& Brinson, M. M. Concepts in Wetland ecology. In: A. E. Lugo, M. M. Brinson and S. brown, eds. Forested Wetlands. Ecosystems of the World 15. Lsevier; Amsterdam, The Netherlands, p.53-85, 1990.

Manfrinato, E. S. "Avaliação do Método Edafo-fitopedológico para o Tratamento Preliminar de Águas". Piracicaba-SP, 98 p. Dissertação (Mestrado). Escola Superior de Agricultura "Luiz de Queiroz". Universidade de São Paulo. 1989.

MINISTÉRIO DA SAÚDE, Portaria 1469, de 29.12.00: Estabelece os procedimentos e responsabilidades relativos ao controle e vigilância da qualidade da água para consumo humano e seu padrão de potabilidade, e dá outras providências. Cap. IV, art. 17, p.12.

Pereira, D.N., Lamparelli, M.C. O ambiente aquático: características gerais. Apostila do curso Diagnóstico de ecossistemas aquáticos. Faculdade de Saúde Pública de São Paulo. Cap II, 2003.

Piveli, R.P., Morita, D.M. Caracterização de águas residuárias - medidas de nutrientes. Apostila do curso Técnicas Analíticas para Caracterização de Águas e Monitoramento de Estações de Tratamento de Água e de Esgotos. Universidade de São Paulo - Escola Politécnica. 1996.

Salati, E. Estudo de Wetlands (Áreas Alagadas) Naturais e Construídas para Proteção e Recuperação dos Recursos Hídricos. São Carlos, SP. 2000. 46 p.

Schwimmer, D. \& Schwimmer, M. Algae and Medicine. In: Jackson, D.F. ed. Algae and man. New York, Plenum Press, 368-412. 1964.

Sendacz, S., Kubo, E., Zooplâncton de Reservatórios do Alto do Tiete. Em:Ecologia de Reservatórios: Estrutura, Função e Aspectos Sociais (Editor: Raoul Henry), FAPESP FUNDIBIO, Botucatu, SP, 1999.

SMA/JPE-EPAL-TAHAL, Diagnóstico Limnológico e ecológico do reservatório do Guarapiranga. Relatório síntese. 93 p, 2000.

Tundisi, J. G. Limnologia e Gerenciamento Integrado de Recursos Hídricos. Ciência \& Ambiente v. 21, p.10-20, 2000.

UNEP. IETC. Planejamento e Gerenciamento de Lagos e Represas: Uma abordagem integrada ao problema de eutrofização. (Editor em português: José Galizia Tundisi), 381 p. São Carlos, SP, 2001.

Vieira, S. Introdução à bioestatística. Ed. Campus, 294 p. Rio de Janeiro, 1989. 
Wetzel, R. G., Limnologia. Fundação Calouste Gulbenkian, Lisboa, 905p. (Translation to Portuguese and preface by Maria José Boavida.), 1993. 
ANEXO 1

SISTEMA PRODUTOR TAQUACETUBA/GUARAPIRANGA PLANO DE CONTINGÊNCIA - CIANOBACTÉRIAS (Revisado em Maio/2002, texto extraído do documento original) 


\section{SISTEMA PRODUTOR TAQUACETUBA/GUARAPIRANGA PLANO DE CONTINGÊNCIA - CIANOBACTÉRIAS (Revisado em Maio/2002, texto extraído do documento original)}

\section{OBjetivo}

Este documento tem como objetivo estabelecer o "Plano de Contingência , para ocorrência de florações de cianobactérias no sistema de abastecimento Billings/Guarapiranga", a partir da revisão do plano estabelecido em 5/10/01, o qual deverá ser implementado, visando a garantia permanente da saúde pública.

\section{Descrição Geral do Plano}

Todas as considerações feitas neste relatório têm como base à publicação da Organização Mundial da Saúde "TOXIC CYANOBACTERIA IN WATER" (OMS, 1999), a Portaria 1469 de 29/12/2000 do Ministério da Saúde, as orientações contidas na Licença de Operação n. 000060 (SMA, 21/08/00) e em dados históricos de monitoramento da SABESP e da CETESB.

O monitoramento será realizado através de análises do fitoplâncton voltadas especificamente para as ocorrências de florações de cianobactérias na água bruta, nos pontos considerados neste plano, bem como por bioensaios com camundongos e determinação de cianotoxinas (Microcistinas, saxitoxinas e cilindrospermopsinas), conforme critérios abaixo elencados. 


\subsection{Pontos de Monitoramento}

Serão adotados os seguintes pontos de monitoramento no sistema Billings - Guarapiranga

\section{Billings}

- corpo central em frente ao braço Bororé

$-B L-102$

- meio do Braço Taquacetuba

$-B L-103$

- captação Taquacetuba

$-B L-105 C$ *

\section{Guarapiranga}

- braço do Rio Parelheiros

- $\quad \mathrm{GU}-107$

- meio do corpo da represa

- $\quad G U-104$

- ponto de captação

- $\mathrm{GU}-101 \mathrm{C}$ *

C = Amostra Composta (coletas de superfície + meio da coluna d'água - profundidade de captação).

Obs.: fica a critério da SABESP compor as amostras ou manter as análises independentes de amostras de superfície e meio da coluna d'água (profundidade de captação). 


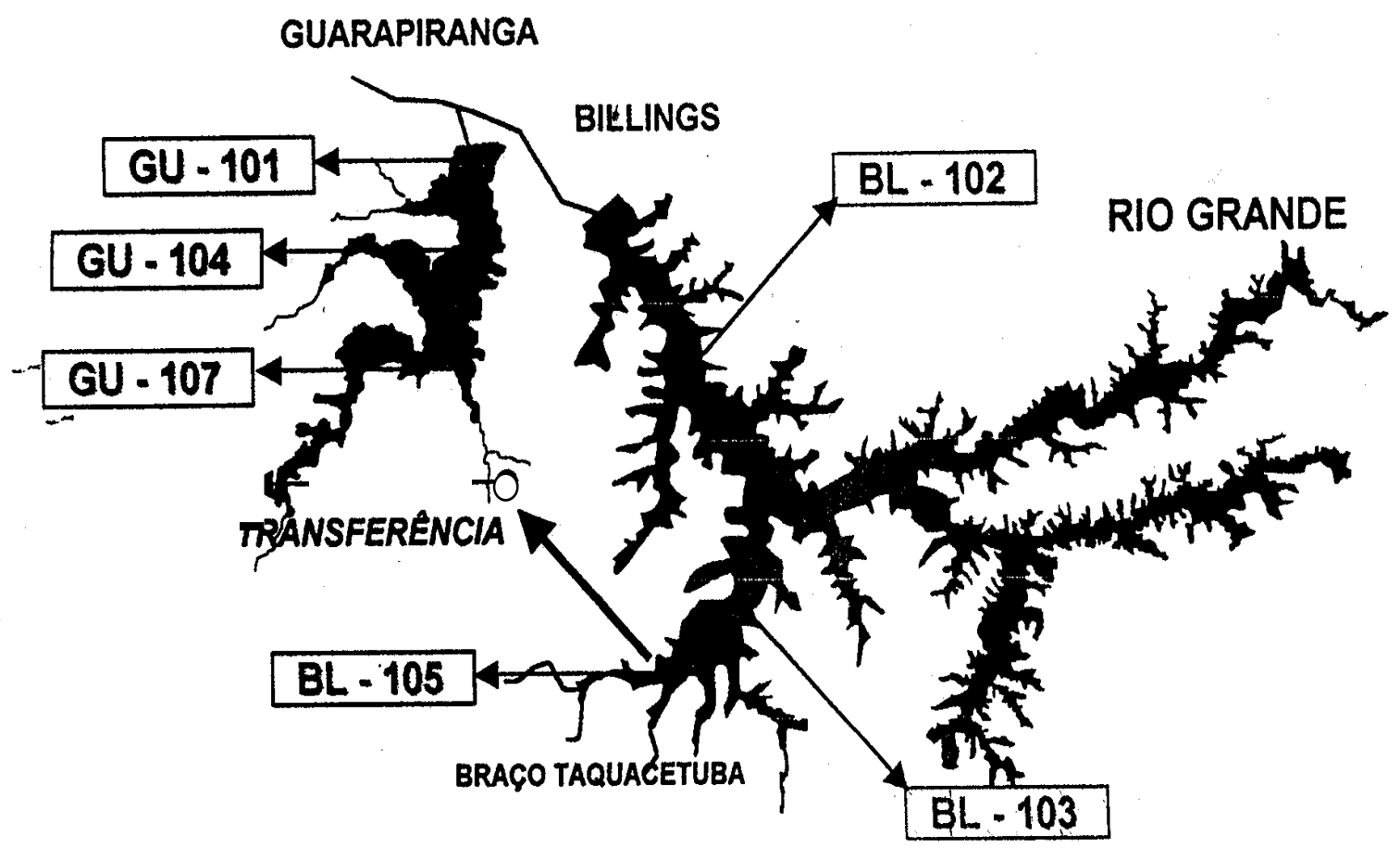

2.2. Freqüência de Amostragem

Será adotada freqüência semanal, para os pontos BL-105C, GU-107 e GU-101C, podendo esta ser alterada de acordo com as condições estabelecidas para os Níveis de Alerta, considerando-se os resultados obtidos nas análises. Para os demais pontos será adotada freqüência quinzenal.

\subsection{Níveis de alerta}

Conforme recomendação da Secretaria de Estado do Meio Ambiente do Governo do Estado de São Paulo, serão adotados os seguintes Níveis de Alerta:

Alerta 1 . contagem de 500 a $20.000 \mathrm{cel} / \mathrm{mL}$ de Cianobactérias - 
ou percepção de odor característico na água bruta, para os pontos BL-105C e GU-101C.

\section{Alerta 2 - contagem de 20.000 a 100.000 cel/mL de Cianobactérias -}

em duas amostras consecutivas a freqüência do monitoramento de contagem será aumentada para duas vezes por semana, para os pontos BL-105 e GU-101. Quando forem atingidos níveis do Alerta 2, serão realizados testes para toxina de algas, para todos os pontos, na seguinte freqüência:

- determinação de Microcistinas,

freqüência semanal para os pontos BL-105C, GU-107 e GU-101C freqüência quinzenal para os pontos BL-102, BL-103 e GU-104

- e, paralelamente, encaminhada sub-amostra para determinação de cilindrospermopsinas e saxitoxinas para os pontos BL-105C, e GU-101C

freqüência semanal.

Quando o Alerta 2 estiver instalado nos pontos GU-104 e/ou GU101, serão tomadas as seguintes providências no processo de tratamento:

1. Redução da pré-cloração na EEAB Guarapiranga e/ou ETA Alto da Boa Vista e adoção de medida comprovada, através de análises laboratoriais, que minimizem a lise celular nesta etapa do processo de tratamento;

2. Proceder à aplicação de carvão ativado em pó na EEAB Guarapiranga, até que seja comprovado, através de análises 
laboratoriais, a ausência ${ }^{1}$ de Microcistinas nas amostras de água coletadas;

3. Utilização da intercloração na ETA Alto da Boa Vista Estabelecer um tempo mínimo de contato de 30 minutos, com concentração de cloro residual livre igual ou superior a 0,5 mg/L.

4. Determinação de cianotoxinas (Microcistinas ou outras toxinas) na água final da ETA ABV obedecerá às mesmas freqüências dos pontos de captação, e serão considerados os limites de toxinas recomendados pela Portaria 1469, que são de 1,0 $\mu \mathrm{g} / \mathrm{L}$ para Microcistinas, 15,0 $\mu \mathrm{g} / \mathrm{L}$ para cilindrospermopsinas e 3,0 $\mu \mathrm{g} / \mathrm{L}$ para saxitoxinas.

NOTA: Se a concentração de cianotoxinas (Microcistinas e outras toxinas) na água tratada estiver acima do limite proposto, a Secretaria Estadual de Saúde deverá ser comunicada.

Quando esta ocorrência estiver instalada nos demais pontos monitorados, isto é, à exceção dos pontos GU-101C e GU-104, serão avaliados os possíveis impactos dessas ocorrências no ponto de captação da represa Guarapiranga para tomada de providências.

\section{Alerta 3}

\section{Guarapiranga}

para contagem acima de $100.000 \mathrm{cel} / \mathrm{ml}$ de Cianobactérias no ponto

GU-101 - serão realizados testes para toxina de algas através de:

\footnotetext{
${ }^{1}$ ausência = abaixo do limite de detecção do método, o qual não pode ser superior a 0,20 $\mu \mathrm{g} / \mathrm{L}$.
} 


\begin{tabular}{|c|c|c|}
\hline ÁGUA BRUTA & Freqüência & Limites \\
\hline $\begin{array}{l}\text { Bioensaios com } \\
\text { camundongo** }\end{array}$ & - SEMANAL & $\begin{array}{l}\text { DL } 50<500 \text { MG } \\
\text { CÉLULAS PS/KG }\end{array}$ \\
\hline $\begin{array}{l}\text { Determinação de } \\
\text { Microcistinas }\end{array}$ & $\begin{array}{l}\text { - QUANTITATIVO (ELISA): UMA } \\
\text { VEZ POR SEMANA. }\end{array}$ & $\begin{array}{l}\text { VALORES ACIMA DE } \\
1,0 \mu \mathrm{G} / \mathrm{L}\end{array}$ \\
\hline $\begin{array}{l}\text { paralelamente, } \\
\text { encaminhada sub-amostra } \\
\text { para determinação de } \\
\text { cilindrospermopsinas e } \\
\text { saxitoxinas }\end{array}$ & - SEMANAL & $\begin{array}{l}\text { VALORES ACIMA DE 1,5 } \\
\mu \mathrm{G} / \mathrm{L} \text { E } 3,0 \mu \mathrm{G} / \mathrm{L} \text {, } \\
\text { RESPECTIVAMENTE. }\end{array}$ \\
\hline ÁGUA TRATADA & Freqüência & Limites \\
\hline $\begin{array}{l}\text { DETERMINAÇÃO DE: } \\
\text { MICROCISTINAS } \\
\text {-SEMI-QUANTITATIVO } \\
\text { (PRESENÇA/AUSÊNCIA) } \\
\text { - quantitativo (Elisa) }\end{array}$ & $\begin{array}{l}\text { diária - se o semi-quantitativo } \\
\text { detectar presença de } \\
\text { Microcistina a amostra será } \\
\text { encaminhada para o teste } \\
\text { Elisa. } \\
\text { - UMA VEZ POR SEMANA. }\end{array}$ & $\begin{array}{l}\text { VALORES ACIMA DE } \\
1,0 \mu \mathrm{G} / \mathrm{L}\end{array}$ \\
\hline $\begin{array}{l}\text { paralelamente, } \\
\text { encaminhada amostra da } \\
\text { água tratada para } \\
\text { determinação de } \\
\text { cilindrospermopsinas e } \\
\text { saxitoxinas }\end{array}$ & - SEMANAL & $\begin{array}{l}\text { VALORES ACIMA DE 1,5 } \\
\mu \mathrm{G} / \mathrm{L} \text { E } 3,0 \mu \mathrm{G} / \mathrm{L} \text {, } \\
\text { RESPECTIVAMENTE. }\end{array}$ \\
\hline
\end{tabular}


Se confirmada a presença de cianotoxinas na floração superiores aos limites estabelecidos no quadro acima, então será adotada a seguinte medida:

- A SABESP convocará reunião extraordinária e emergencial com técnicas das: Secretaria de Estado do Meio Ambiente/CETESB e Secretaria Estadual de Saúde para avaliação da situação e tomada das decisões cabíveis.

\section{Billings}

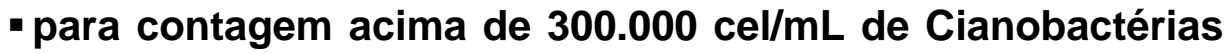
nos ponto BL-105C - serão realizados testes para toxina de algas através de:

\begin{tabular}{|c|c|c|}
\hline & Freqüência & Limites \\
\hline BIOENSAIOS COM CAMUNDONGO & - SEMANAL & $\begin{array}{l}\text { DL } 50<100 \text { MG CÉLULAS } \\
\text { P.S./KG }\end{array}$ \\
\hline $\begin{array}{l}\text { DETERMINAÇÃO DE } \\
\text { MICROCISTINA: } \\
\text { - QUANTITATIVO (ELISA): }\end{array}$ & $\begin{array}{l}\text { - DUAS VEZES POR } \\
\text { SEMANA. }\end{array}$ & VALORES ACIMA DE $2,0 \mu \mathrm{G} / \mathrm{L}$ \\
\hline $\begin{array}{l}\text { paralelamente, } \\
\text { encaminhada sub-amostra } \\
\text { para determinação de } \\
\text { cilindrospermopsinas e } \\
\text { saxitoxinas }\end{array}$ & - SEMANAL & $\begin{array}{l}\text { VALORES ACIMA DE 3,0 } \mu \mathrm{G} / \mathrm{L} \text { E } \\
6,0 \mu \mathrm{G} / \mathrm{L}, \mathrm{RESPECTIVAMENTE.}\end{array}$ \\
\hline
\end{tabular}

No Alerta 3, se confirmada a presença de cianotoxinas na floração, superiores aos limites acima estabelecidos, então será adotada a seguinte medida:

A SABESP reduzirá o bombeamento para $2 \mathrm{~m}^{3} / \mathrm{s}$, ou suspenderá todo o bombeamento, e convocará reunião extraordinária e emergencial com 
técnicos das: Secretaria de Estado do Meio Ambiente/CETESB e Secretaria Estadual de Saúde para avaliação da situação e tomada das decisões cabíveis. 


\section{ANEXO 2}

Dados de monitoramento de qualidade de água do ponto GU 213 - entrada da Várzea. 


\begin{tabular}{|c|c|c|c|c|c|c|c|c|c|c|c|c|c|c|c|}
\hline \multicolumn{16}{|c|}{$\begin{array}{l}\text { DIVISÃO DE MONITORAMENTO E INFORMAÇÕES AMBIENTAIS DA PRODUÇÃO - AAHM } \\
\text { MONITORAMENTO DA QUALIDADE DA ÁGUA }\end{array}$} \\
\hline \multicolumn{5}{|c|}{ BACIA GUARAPIRANGA } & \multicolumn{11}{|c|}{ GU-213: RIO PARELHEIROS - MARGEM DIREITA - ponte da estrada Jaceguava } \\
\hline \multirow[b]{3}{*}{ 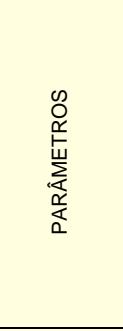 } & \multirow[b]{3}{*}{ 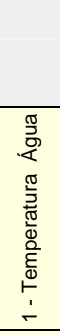 } & \multirow[b]{3}{*}{ 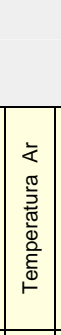 } & \multirow[b]{3}{*}{$\begin{array}{l}\frac{\pi}{0} \\
\frac{0}{0} \\
0 \\
\frac{\pi}{0} \\
\frac{\pi}{0} \\
\frac{0}{1}\end{array}$} & \multirow[b]{3}{*}{$\begin{array}{l}\frac{\pi}{\pi} \\
3_{U}^{2} \\
\end{array}$} & \multirow{2}{*}{\multicolumn{6}{|c|}{ RESULTADOS FÍSICO-QUÍMICOS }} & \multicolumn{5}{|c|}{ MICROBIOLÓGICOS } \\
\hline & & & & & & & & & & & \multicolumn{2}{|c|}{ Bacteriológicos } & & \multicolumn{2}{|c|}{ Toxicicidade } \\
\hline & & & & & $\begin{array}{l}\dot{c} \\
\dot{U} \\
\dot{\Delta}\end{array}$ & 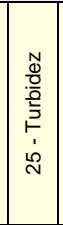 & $\begin{array}{l}I \\
\text { I } \\
\dot{1} \\
\stackrel{m}{m}\end{array}$ & 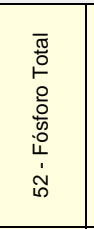 & 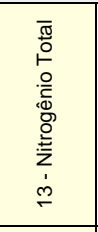 & $\begin{array}{l}8 \\
\text { O } \\
\dot{y} \\
\dot{y}\end{array}$ & 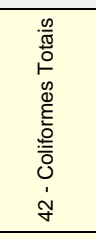 & 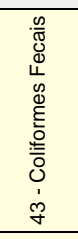 & Total de Células & 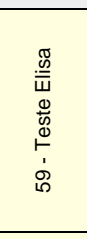 & 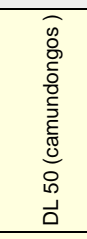 \\
\hline UNIDADE & ${ }^{\circ} \mathrm{C}$ & ${ }^{\circ} \mathrm{C}$ & Hora & - & U.C. & NTU & - & $\mathrm{mg} P / \mathrm{L}$ & $\mathrm{mg} \mathrm{N} / \mathrm{L}$ & $\mathrm{mg} \mathrm{O} 2 / \mathrm{L}$ & \multicolumn{2}{|c|}{ NMP / $100 \mathrm{~mL}$} & $\mathrm{Cel} / \mathrm{mL}$ & $\mu \mathrm{g} / \mathrm{L}$ & $\mathrm{mg} / \mathrm{Kg}$ \\
\hline \multirow{3}{*}{$\begin{array}{l}\text { PADRÃO } \\
\text { CONAMA }\end{array}$} & & & & & - & 40 & 6 a 9 & 0,025 & - & - & 1.000 & 200 & & & \\
\hline & & & & & 75 & 100 & 6 a 9 & 0,025 & - & - & 5.000 & 1.000 & & & \\
\hline & & & & & 75 & 100 & 6 a 9 & 0,025 & - & & 20.000 & 4.000 & & & \\
\hline $3 / 6 / 2003$ & 20 & 26 & $09: 40$ & não & 50 & 8,4 & 8 & 0,073 & 1,1 & 29 & 12.960 & 2.430 & 237621,3 & 0,636 & \\
\hline $17 / 6 / 2003$ & 20 & 25 & $10: 40$ & Não & 50 & 7,6 & 7,8 & 0,100 & 1,08 & 27 & 4100 & $<1000$ & 187592,7 & 0,595 & \\
\hline $25 / 6 / 2003$ & 20 & 25 & $11: 10$ & Não & 50 & 6,2 & 7,9 & 0,093 & 1 & 30 & 8600 & $<1000$ & 224507,4 & 0,483 & \\
\hline $1 / 7 / 2003$ & 19 & 20 & $10: 00$ & Não & 40 & 6,8 & 7,7 & 0,121 & 1,63 & 34 & 5360 & 310 & 243224,6 & 0,684 & \\
\hline 9/7/2003 & 19 & 20 & $08: 30$ & Não & 50 & 7,7 & 7,8 & 0,122 & 1,29 & 29 & 178020 & 1100 & 395955,1 & 0,521 & \\
\hline $15 / 7 / 2003$ & 17 & 20 & $09: 20$ & Não & 50 & 7,5 & 7,7 & 0,126 & 1,39 & 29 & 17850 & 850 & 203268 & 0,314 & \\
\hline $23 / 7 / 2003$ & 21 & 24 & $11: 00$ & Fracas & 50 & 7 & 8,5 & 0,212 & 1,39 & 38 & 57600 & 6300 & 1030057 & 0,454 & \\
\hline 29/7/2003 & 19 & 19 & 09:30 & não & 50 & 7,3 & 7,5 & 0,249 & 1,35 & 38 & 41060 & 2750 & 796913,1 & 0,691 & \\
\hline $5 / 8 / 2003$ & 20 & 28 & $15: 30$ & Não & 35 & 8,1 & 7,5 & 0,157 & 1,62 & 29 & - & - & 232850,6 & 0,363 & \\
\hline $12 / 8 / 2003$ & 17 & 18 & $10: 40$ & não & 40 & 6,9 & 7,8 & 0,117 & 1,45 & 29 & 13170 & 1080 & 735037,6 & - & \\
\hline $20 / 8 / 2003$ & 18 & 26 & 11:30 & não & 40 & 7,1 & 7,6 & 0,229 & 4,6 & 27 & 54750 & 3360 & 143228,7 & 0,185 & \\
\hline $26 / 8 / 2003$ & 16 & 14 & $10: 10$ & Não & 40 & 9 & 7,8 & 0,178 & 1,8 & 32 & 155310 & 17250 & 264182,4 & - & \\
\hline $2 / 9 / 2003$ & 18 & 18 & $10: 20$ & Não & 40 & 7 & 8,1 & 0,344 & 1,26 & 33 & 11870 & 135 & 208665,9 & & \\
\hline 9/9/2003 & 21 & 22 & $10: 30$ & Não & 40 & 6,1 & 8,6 & 0,131 & 0,98 & 29 & 92080 & 7590 & 170879,6 & - & \\
\hline $16 / 9 / 2003$ & 18 & 21 & $15: 00$ & Médias & 40 & 8,3 & 7,8 & 0,127 & 1,4 & 26 & 61300 & 5400 & 173525,7 & 0,305 & \\
\hline $24 / 9 / 2003$ & 21 & 30 & $10: 50$ & Não & 40 & 7,6 & 7,9 & 0,136 & 1,34 & 21 & 72700 & 3360 & 147018,5 & & \\
\hline $30 / 9 / 2003$ & 19 & 22 & $10: 15$ & não & 40 & 6 & 7,8 & 0,117 & 1,34 & 24 & 29090 & 980 & 260353,7 & 0,402 & \\
\hline $7 / 10 / 2003$ & 22 & 25 & $10: 35$ & não & 40 & 5,6 & 7,6 & 0,123 & 1,28 & 25 & 34480 & $<100$ & 191147 & 0,503 & \\
\hline $14 / 10 / 2003$ & 20 & 19 & $10: 10$ & fracas & 40 & 8,1 & 7,9 & 0,114 & 1,04 & 41 & 19863 & 2851 & 234484,5 & 0,695 & \\
\hline $22 / 10 / 2003$ & 22 & 27 & 11:25 & fracas & 60 & 9,4 & 8,6 & 0,102 & 1,29 & 28 & 38730 & 1090 & 287129,6 & 1,536 & \\
\hline $28 / 10 / 2003$ & 22 & 22 & $10: 30$ & fracas & 40 & 8,4 & 7,7 & 0,11 & 1,3 & 27 & 12997 & 1850 & 172725,5 & 2,126 & \\
\hline $4 / 11 / 2003$ & 20 & 17 & 11:30 & Médias & 40 & 8 & 8,1 & 0,096 & 1,2 & 25 & 7270 & 74 & 339709,5 & 23,996 & \\
\hline $11 / 11 / 2003$ & 21 & 25 & $10: 05$ & Não & 40 & 10,1 & 8,8 & 0,131 & 1,21 & 28 & $>24192$ & 3130 & 605746,8 & 1,616 & \\
\hline $19 / 11 / 2003$ & 22,5 & 28,5 & $12: 10$ & Fracas & 60 & 13,8 & 8,4 & 0,156 & 1,2 & 31 & 38.800 & 3.100 & 553301,8 & 4,364 & \\
\hline $25 / 11 / 2003$ & 24 & 27 & $10: 30$ & Não & 60 & 13 & 8,9 & 0,158 & 1,04 & 34 & 12.033 & 712 & 846601 & 6,067 & \\
\hline $2 / 12 / 2003$ & 20 & 26 & 09:20 & Médias & 60 & 12,7 & 8,5 & 0,168 & 1,04 & 35 & $>24192$ & 2.063 & 1240350 & 9,040 & \\
\hline 9/12/2003 & 24 & 20 & $10: 45$ & Fracas & 60 & 15 & 8,9 & 0,179 & 1,10 & 37 & 32.550 & 933 & 1336425 & 7,680 & \\
\hline $17 / 12 / 2003$ & 25 & 20 & $11: 40$ & Fortes & 60 & 17,3 & 7,7 & 0,162 & 1,13 & 36 & 51.720 & 4.570 & 900913,1 & 3,977 & \\
\hline
\end{tabular}




\begin{tabular}{|c|c|c|c|c|c|c|c|c|c|c|c|c|c|c|c|}
\hline \multicolumn{16}{|c|}{$\begin{array}{l}\text { DIVISÃO DE MONITORAMENTO E INFORMAÇÕES AMBIENTAIS DA PRODUÇÃO - AAHM } \\
\text { MONITORAMENTO DA QUALIDADE DA ÁGUA }\end{array}$} \\
\hline \multicolumn{5}{|c|}{ BACIA GUARAPIRANGA } & \multicolumn{11}{|c|}{ GU-213: RIO PARELHEIROS - MARGEM DIREITA - ponte da estrada Jaceguava } \\
\hline \multirow[b]{3}{*}{ 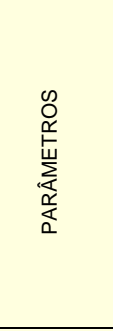 } & \multirow[b]{3}{*}{ 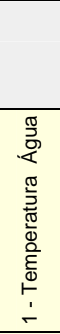 } & \multirow[b]{3}{*}{ 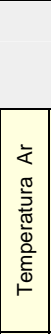 } & \multirow[b]{3}{*}{$\begin{array}{l}\frac{\pi}{0} \\
\frac{0}{0} \\
0 \\
\frac{\pi}{0} \\
\frac{\pi}{0} \\
\text { 오 }\end{array}$} & \multirow[b]{3}{*}{ 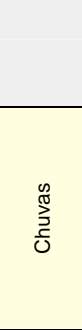 } & \multirow{2}{*}{\multicolumn{6}{|c|}{ RESULTADOS FíSICO-QUÍMICOS }} & \multicolumn{5}{|c|}{ MICROBIOLÓGICOS } \\
\hline & & & & & & & & & & & \multicolumn{2}{|c|}{ Bacteriológicos } & & \multicolumn{2}{|c|}{ Toxicicidade } \\
\hline & & & & & $\begin{array}{l}\dot{N} \\
\dot{d} \\
\dot{d}\end{array}$ & 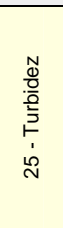 & $\begin{array}{l}I \\
\frac{1}{2} \\
1 \\
p\end{array}$ & 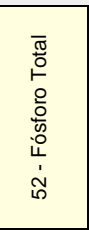 & 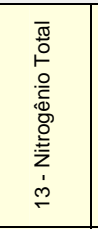 & $\begin{array}{l}\text { O } \\
\text { व } \\
\dot{y} \\
\dot{y}\end{array}$ & 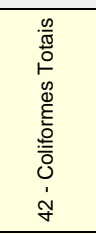 & 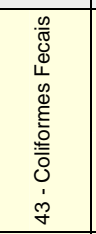 & Total de Células & 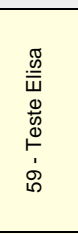 & 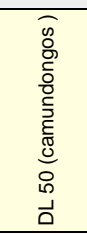 \\
\hline UNIDADE & ${ }^{\circ} \mathrm{C}$ & ${ }^{\circ} \mathrm{C}$ & Hora & - & U.C. & NTU & - & $\mathrm{mg} \mathrm{P} / \mathrm{L}$ & $\mathrm{mg} \mathrm{N} / \mathrm{L}$ & $\mathrm{mg} \mathrm{O} 2 / \mathrm{L}$ & \multicolumn{2}{|c|}{ NMP / $100 \mathrm{~mL}$} & $\mathrm{Cel} / \mathrm{mL}$ & $\mu \mathrm{g} / \mathrm{L}$ & $\mathrm{mg} / \mathrm{Kg}$ \\
\hline \multirow{3}{*}{$\begin{array}{l}\text { PADRÃO } \\
\text { CONAMA }\end{array}$} & & & & & - & 40 & 6 a 9 & 0,025 & - & - & 1.000 & 200 & & & \\
\hline & & & & & 75 & 100 & 6 a 9 & 0,025 & - & - & 5.000 & 1.000 & & & \\
\hline & & & & & 75 & 100 & 6 a 9 & 0,025 & - & & 20.000 & 4.000 & & & \\
\hline $6 / 1 / 2004$ & 25 & 28 & $10: 55$ & Não & 40 & 13,2 & 8,2 & 0,140 & 1,44 & $<10$ & $>241920$ & 52.470 & 551506,1 & 3,048 & \\
\hline $13 / 1 / 2004$ & 25 & 26 & 10:30 & Médias & 40 & 7,6 & 7,5 & 0,131 & 0,97 & 22 & 86.640 & 141.140 & 305271,1 & 1,467 & \\
\hline $21 / 1 / 2004$ & 25 & 26 & 11:15 & Fracas & 40 & 10,2 & 7,7 & 0,119 & 1,05 & 21 & 11.530 & 860 & 257660,1 & 1,655 & \\
\hline $27 / 1 / 2004$ & 23,5 & 24,5 & $08: 30$ & Médias & 80 & 19,7 & 7,5 & 0,117 & 0,59 & 28 & 86.640 & 3.590 & 264564,3 & $<0,1$ & \\
\hline $3 / 2 / 2004$ & 26 & 30 & $10: 10$ & Médias & 60 & 13,5 & 8,7 & 0,104 & 0,66 & 33 & 23.590 & 860 & 428838,2 & 1,202 & \\
\hline $10 / 2 / 2004$ & 22 & 27 & $10: 30$ & Não & 40 & 11,3 & 7,6 & 0,054 & 1,02 & 19 & 26.130 & 940 & 185208,5 & 1,254 & \\
\hline $18 / 2 / 2004$ & 24 & 30 & $11: 20$ & Fracas & & 12 & 8,3 & 0,082 & & 39 & 69.700 & $<1000$ & 431386,4 & 0,938 & \\
\hline $2 / 3 / 2004$ & 25 & 27 & 10:47 & Não & 40 & 9,3 & 7,8 & 0,086 & 0,81 & 26 & 19.863 & 199 & 342754,6 & 0,528 & \\
\hline $9 / 3 / 2004$ & 22,5 & 28 & 10:45 & Não & 40 & 11,4 & 7,7 & 0,072 & 0,85 & 24 & 18.720 & 200 & 287018,5 & 0,918 & \\
\hline $17 / 3 / 2004$ & 23 & 25 & $11: 30$ & Não & & 9,3 & 7,5 & 0,110 & 1,07 & 25 & 20.300 & 2.000 & 190325,2 & 0,413 & \\
\hline $23 / 3 / 2004$ & 23 & 26 & 10:45 & Fracas & 40 & 22,5 & 7,5 & 0,076 & 1,08 & 22 & 29.870 & 4.500 & 223195,6 & 0,417 & \\
\hline $30 / 3 / 2004$ & 22 & 27 & $10: 40$ & Não & 40 & 7,43 & 7,7 & 0,074 & 0,95 & 21 & 41.000 & 2.000 & 571656,7 & 0,263 & \\
\hline $6 / 4 / 2004$ & 27 & 25 & 12:00 & Fortes & 360 & 281 & 7,7 & 0,118 & 1,20 & 32 & 387.300 & 27.500 & 475544 & 0,340 & \\
\hline $13 / 4 / 2004$ & 23 & 28 & $10: 20$ & Não & 40 & 6,46 & 7,5 & 0,064 & 1,13 & 21 & 13.400 & 1.000 & 534995,3 & 0,210 & \\
\hline $20 / 4 / 2004$ & 23 & 22 & $18: 40$ & Fracas & 60 & 10,6 & 7,7 & 0,063 & 0,97 & 18 & 37.400 & 1.000 & 325608,7 & 0,470 & \\
\hline $28 / 4 / 2004$ & 22 & 23 & 11:00 & - & & 5,75 & 7,5 & 0,063 & 1,01 & 19 & 17.300 & $<1$ & 264029,6 & 0,504 & \\
\hline
\end{tabular}


ANEXO 3

Dados de monitoramento de qualidade de água do ponto GU 107 - saída da Várzea. 


\begin{tabular}{|c|c|c|c|c|c|c|c|c|c|c|c|c|c|c|c|}
\hline \multicolumn{16}{|c|}{$\begin{array}{l}\text { DIVISÃO DE MONITORAMENTO E INFORMAÇÕES AMBIENTAIS DA PRODUÇÃO - AAHM } \\
\text { MONITORAMENTO DA QUALIDADE DA ÁGUA }\end{array}$} \\
\hline \multicolumn{5}{|c|}{ REPRESA GUARAPIRANGA } & \multicolumn{11}{|c|}{ GU-107S: BRAÇO DO RIO PARELHEIROS - SUPERFÍCIE } \\
\hline \multirow[b]{3}{*}{ 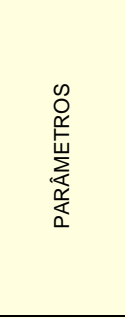 } & \multirow[b]{3}{*}{ 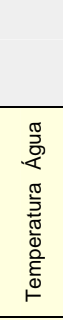 } & \multirow[b]{3}{*}{ 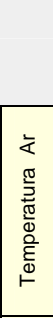 } & \multirow[b]{3}{*}{$\begin{array}{l}\frac{\pi}{0} \\
\frac{0}{0} \\
0 \\
\frac{\pi}{0} \\
\frac{\pi}{0} \\
\text { 모 }\end{array}$} & \multirow[b]{3}{*}{$\begin{array}{l}\overbrace{}^{n} \\
\text { 胥 }\end{array}$} & \multirow{2}{*}{\multicolumn{6}{|c|}{ FÍsıco-Químıcos }} & \multicolumn{5}{|c|}{ MICROBIOLÓGICOS } \\
\hline & & & & & & & & & & & \multicolumn{2}{|c|}{ Bacteriológicas } & & \multicolumn{2}{|c|}{ Toxicicidade } \\
\hline & & & & & $\bar{u}$ & \multirow[t]{2}{*}{$\begin{array}{c}\frac{N}{0} \\
\frac{0}{0} \frac{1}{1} \\
\end{array}$} & $\frac{I}{2}$ & \multirow[t]{2}{*}{ 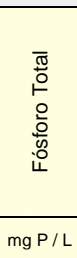 } & \multirow[t]{2}{*}{ 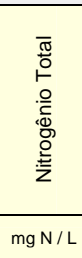 } & 움 & 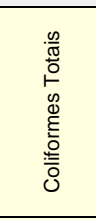 & 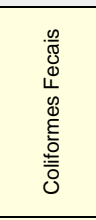 & $\begin{array}{l}\text { Cianobactérias } \\
\text { Total de Células }\end{array}$ & 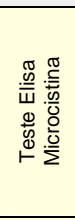 & 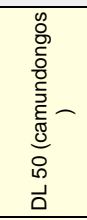 \\
\hline UNIDADE & ${ }^{\circ} \mathrm{C}$ & ${ }^{\circ} \mathrm{C}$ & Hora & - & U.C. & & - & & & $\mathrm{mg} \mathrm{O} / \mathrm{L}$ & \multicolumn{2}{|c|}{ NMP / $100 \mathrm{~mL}$} & $\mathrm{Cel} / \mathrm{mL}$ & $\mu \mathrm{g} / \mathrm{L}$ & $\mathrm{mg} / \mathrm{Kg}$ \\
\hline \multirow{3}{*}{$\begin{array}{l}\text { PADRÃO } \\
\text { CONAMA }\end{array}$} & & & & & - & 40 & 6 a 9 & 0,025 & - & - & 1.000 & 200 & - & - & - \\
\hline & & & & & 75 & 100 & 6 a 9 & 0,025 & - & - & 5.000 & 1.000 & - & - & - \\
\hline & & & & & 75 & 100 & 6 a 9 & 0,025 & - & - & 20.000 & 4.000 & - & - & - \\
\hline $2 / 6 / 2003$ & 20 & 23 & $11: 10$ & Não & 40 & 5,1 & 7,1 & 0,126 & 1,31 & & & & 33241,5 & $<0,1$ & \\
\hline $9 / 6 / 2003$ & 21 & 22 & $11: 30$ & Não & 60 & 8,4 & 7,0 & 0,157 & 1,6 & & 92080 & 11300 & 39494,1 & $<0,1$ & $\begin{array}{c}638.22 \\
\text { baixa }\end{array}$ \\
\hline $16 / 6 / 2003$ & 22 & 24 & $12: 10$ & Não & 40 & 4,7 & 7,1 & 0,169 & 1,33 & & 77010 & 64440 & 46441 & $<0,1$ & \\
\hline $23 / 6 / 2003$ & 20 & 23 & $11: 10$ & Não & 40 & 3,5 & 7,1 & 0,098 & 1,41 & & 43520 & 4190 & 36354,7 & 0,167 & \\
\hline $30 / 6 / 2003$ & 19 & 19 & $11: 25$ & Não & 40 & 4,7 & 7,0 & 0,123 & 1,21 & & 38730 & 4880 & 49265,5 & 0,234 & \\
\hline 7/7/2003 & 18 & 18 & $11: 10$ & Não & 40 & 5,1 & 7,0 & & 1,64 & 17 & 92080 & 10390 & 74121,4 & 0,243 & $\begin{array}{c}>696,75 \\
\text { Baixa } \\
\end{array}$ \\
\hline $14 / 7 / 2003$ & 17 & 18 & $10: 10$ & Não & 40 & 5,4 & 7,1 & 0,189 & 1,89 & & 46110 & 4130 & 127469 & 0,209 & \\
\hline $21 / 7 / 2003$ & 18 & 23 & 11:15 & Não & 50 & 5,6 & 7,1 & 0,224 & 1,74 & & 92080 & 5980 & 142120,5 & 0,191 & $\begin{array}{c}>743,25 \\
\text { Baixa }\end{array}$ \\
\hline $28 / 7 / 2003$ & 20 & 20 & $11: 50$ & Não & 50 & 6,6 & 7,1 & 0,248 & 1,87 & & 111990 & 9840 & 158076,4 & 0,297 & \\
\hline 4/8/2003 & 20 & 20 & $10: 35$ & Não & 40 & 7,5 & 7,2 & 0,209 & & & 111990 & 9330 & 120778,5 & & $\begin{array}{l}260,38 \\
\text { Média }\end{array}$ \\
\hline $11 / 8 / 2003$ & 18 & 16 & 11:10 & Médias & 40 & 8,8 & 7,2 & 0,243 & 2,66 & 26 & 155310 & 13740 & 118445 & 0,237 & \\
\hline $18 / 8 / 2003$ & 17 & 17 & $11: 00$ & Não & 40 & 8,6 & 7,3 & 0,256 & 1,91 & & 64880 & 6770 & 146762,8 & $<0,1$ & $\begin{array}{c}>787,5 \\
\text { Baixa }\end{array}$ \\
\hline $1 / 9 / 2003$ & 17 & 16 & $11: 25$ & Médias & 40 & 12 & 7,4 & 0,162 & 1,94 & & 86640 & 7710 & 127595,5 & & $\begin{array}{c}740,05 \\
\text { Baixa }\end{array}$ \\
\hline 8/9/2003 & 21 & 25 & 11:15 & Não & 40 & 15 & 7,7 & 0,233 & & & $>241920$ & 31300 & 136273,6 & & \\
\hline $15 / 9 / 2003$ & 19 & 20 & $11: 45$ & Não & 40 & 11,9 & 7,6 & 0,174 & 1,99 & 24 & 129900 & 13500 & 142405,8 & & $\begin{array}{l}405,56 \\
\text { Média }\end{array}$ \\
\hline $22 / 9 / 2003$ & 21 & 25 & $10: 25$ & Não & 50 & 12,9 & 7,8 & 0,182 & 2,04 & & $>241920$ & 173290 & 130691 & $<0,1$ & \\
\hline 29/9/2003 & 21 & 18 & $12: 00$ & Não & 60 & 16,1 & 7,7 & 0,178 & 1,92 & & 241920 & 21870 & 167747,5 & & $\begin{array}{l}340,99 \\
\text { Média }\end{array}$ \\
\hline $6 / 10 / 2003$ & 22 & 30 & $10: 30$ & Não & 60 & 16,2 & 7,3 & 0,169 & 1,81 & & 57940 & 9320 & & & \\
\hline $13 / 10 / 2003$ & 20 & 21 & $11: 15$ & não & 80 & 18,9 & 7,2 & 0,152 & 2,3 & 25 & 241.920 & 17.250 & 143864,6 & & $\begin{array}{l}279,63 \\
\text { Média }\end{array}$ \\
\hline $30 / 10 / 2003$ & 22 & 23 & $14: 40$ & fracas & & & & & & & & & 134047,6 & 0,547 & \\
\hline $3 / 11 / 2003$ & 20 & 18 & $13: 30$ & médias & & & & & & & & & 223340,1 & & \\
\hline $6 / 11 / 2003$ & 20,5 & 23 & $11: 55$ & fracas & 50 & 18,8 & 7,7 & 0,151 & 1,69 & & 141.360 & 38.730 & 0 & & \\
\hline $10 / 11 / 2003$ & 25 & 30 & $11: 45$ & não & 60 & 14,1 & 7,6 & 0,17 & 2,51 & & 155.310 & 19.890 & 550532,8 & 0,6 & $\begin{array}{l}376,72 \\
\text { Média }\end{array}$ \\
\hline $17 / 11 / 2003$ & 24 & 24 & $12: 20$ & fortes & 100 & 36 & 7,5 & 0,263 & 2,32 & 30 & $>241920$ & 104.620 & 488533,8 & 1,5 & \\
\hline $24 / 11 / 2003$ & 23 & 24 & $10: 30$ & Não & 75 & 28 & 7,6 & 0,174 & 2,81 & & 98.040 & 13.130 & 450644,2 & 1,53 & $\begin{array}{l}278,11 \\
\text { Média }\end{array}$ \\
\hline $1 / 12 / 2003$ & 22,5 & 24 & 11:15 & fracas & 60 & 15,2 & 7,2 & 0,236 & 2,00 & 23 & 141.360 & 13.330 & 47728,3 & 0,416 & \\
\hline $8 / 12 / 2003$ & 25 & 28 & $12: 00$ & não & 50 & 12 & 7,5 & 0,135 & 1,52 & 23 & 104.620 & 15.650 & 135321,4 & 0,7 & $\begin{array}{l}351,63 \\
\text { Média }\end{array}$ \\
\hline $15 / 12 / 2003$ & 27 & 31 & $11: 00$ & Médias & 80 & 14,1 & 8,7 & 0,151 & 0,86 & & 75.550 & 17.220 & 207522,1 & 1,234 & \\
\hline $21 / 12 / 2003$ & 23,5 & 23 & $10: 15$ & médias & 80 & 19,1 & 7,2 & 0,188 & 1,54 & 30 & 198.630 & 28.510 & 429847,5 & 1,390 & \\
\hline $28 / 12 / 2003$ & 24 & 25 & $09: 50$ & Não & 50 & 15,1 & 7,7 & 0,161 & 1,16 & 27 & 98.040 & 12.910 & 616892 & 0,874 & \\
\hline
\end{tabular}




\begin{tabular}{|c|c|c|c|c|c|c|c|c|c|c|c|c|c|c|c|}
\hline \multicolumn{16}{|c|}{ DIVISÃO DE MONITORA } \\
\hline \multicolumn{5}{|c|}{ REPRESA GUARAPIRANGA } & \multicolumn{11}{|c|}{ GU-107S: BRAÇO DO RIO PARELHEIROS - SUPERFÍCIE } \\
\hline \multirow[b]{3}{*}{ 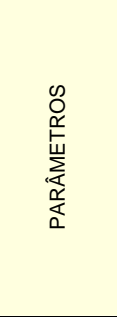 } & \multirow[b]{3}{*}{ 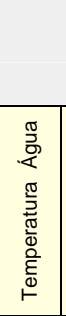 } & \multirow[b]{3}{*}{ 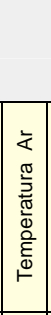 } & \multirow[b]{3}{*}{$\begin{array}{l}\frac{\pi}{0} \\
\frac{0}{0} \\
0 \\
\frac{\pi}{0} \\
\frac{\pi}{0} \\
\text { 오 }\end{array}$} & \multirow[b]{3}{*}{ 胥 } & \multirow{2}{*}{\multicolumn{6}{|c|}{ FísICO-QUímICOS }} & \multicolumn{5}{|c|}{ MICROBIOLÓGICOS } \\
\hline & & & & & & & & & & & \multicolumn{2}{|c|}{ Bacteriológicas } & & \multicolumn{2}{|c|}{ Toxicicidade } \\
\hline & & & & & $\bar{u}$ & 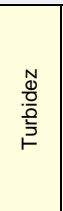 & I & \multirow[t]{2}{*}{ 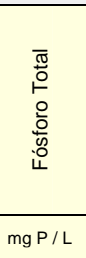 } & \multirow[t]{2}{*}{ 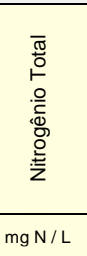 } & ○ & 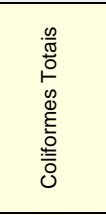 & 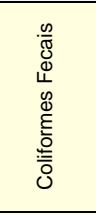 & $\begin{array}{c}\text { Cianobactérias Total } \\
\text { de Células }\end{array}$ & 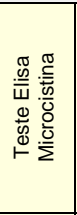 & 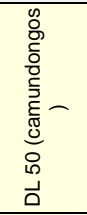 \\
\hline UNIDADE & ${ }^{\circ} \mathrm{C}$ & ${ }^{\circ} \mathrm{C}$ & Hora & & U.c. & NTU & - & & & $\mathrm{mg} \mathrm{O2/L}$ & \multicolumn{2}{|c|}{ NMP / 100 mL } & Cel / mL & $\mu \mathrm{g} / \mathrm{L}$ & $\mathrm{mg} / \mathrm{Kg}$ \\
\hline \multirow{3}{*}{$\begin{array}{l}\text { PADRÃO } \\
\text { CONAMA }\end{array}$} & & & & & - & 40 & 6 a 9 & 0,025 & - & - & 1.000 & 200 & - & - & - \\
\hline & & & & & 75 & 100 & 6 a 9 & 0,025 & - & - & 5.000 & 1.000 & - & - & - \\
\hline & & & & & 75 & 100 & 6 a 9 & 0,025 & - & - & 20.000 & 4.000 & - & - & - \\
\hline $5 / 1 / 2004$ & 25 & 29 & $14: 10$ & Não & 60 & 15,3 & 7,4 & 0,212 & 1,93 & 34 & $>241920$ & 52.470 & 396278,9 & 1,344 & \\
\hline $12 / 1 / 2004$ & 24 & 26 & $11: 40$ & Não & 60 & 11,1 & 7,2 & 0,212 & 1,12 & 24 & 98.040 & 20.140 & 253396,8 & 0,942 & \\
\hline 19/1/2004 & 23 & 23 & 09:50 & Não & 50 & 12,9 & 7,2 & 0,162 & 1,48 & & $>241920$ & 129.970 & 126889,8 & 0,491 & \\
\hline $27 / 1 / 2004$ & 23 & 22 & $10: 15$ & fortes & 90 & 24,5 & 7,2 & 0,157 & 1,35 & 24 & 141.360 & 20.140 & 98849,5 & $<0,1$ & \\
\hline 2/2/2004 & 26 & 27 & $10: 25$ & fracas & 125 & 34,5 & 7,8 & 0,276 & 0,91 & 23 & 72.700 & 8.130 & 48614,3 & 0,412 & \\
\hline $9 / 2 / 2004$ & 24 & 22 & $11: 20$ & Não & 60 & 10,6 & 7,2 & 0,122 & 1,47 & & 179.300 & 17.500 & 97480,5 & 0,515 & \\
\hline $16 / 2 / 2004$ & 24 & 25 & $10: 50$ & fracas & 65 & 10,5 & 7,2 & 0,101 & 1,02 & 13 & 218.700 & 17.500 & 50949 & 0,200 & \\
\hline $26 / 2 / 2004$ & 22 & 19 & $10: 00$ & Médias & 60 & 10,4 & 7,0 & 0,106 & 1,57 & 14 & 141.360 & 15.290 & 102014,9 & $<0,1$ & \\
\hline $1 / 3 / 2004$ & 28 & 30 & $12: 00$ & Não & 60 & 7,1 & 7,1 & 0,101 & & 18 & 92.080 & 20.980 & 36351,2 & 0,519 & \\
\hline $8 / 3 / 2004$ & 24 & 29 & 11:12 & Não & 40 & 7,2 & 7,3 & 0,073 & 0,75 & & 33.100 & 12.200 & 29388,5 & 0,208 & \\
\hline $15 / 3 / 2004$ & 24 & 25 & $12: 50$ & Fortes & 40 & 5,9 & 7,1 & 0,115 & 1,10 & 16 & $>24192$ & 5.748 & 99712,5 & 0,612 & \\
\hline $25 / 3 / 2004$ & 23 & 21 & $10: 25$ & - & & & & & & & & & 13108,5 & 0,864 & \\
\hline $29 / 3 / 2004$ & 27 & 30 & 11:35 & fracas & 40 & 4,5 & 7,7 & 0,063 & 0,59 & 12 & & & 25125,2 & $<0,1$ & \\
\hline $5 / 4 / 2004$ & 26 & 29 & $11: 10$ & Médias & 40 & 6,55 & 6,9 & 0,170 & 1,18 & 20 & 173.290 & 14.830 & 76406,2 & 0,289 & \\
\hline $7 / 4 / 2004$ & 23 & 26 & $10: 50$ & fortes & & & & & & & & & 71940,8 & 0,232 & \\
\hline $8 / 4 / 2004$ & 25 & 28 & $10: 40$ & Não & & & & & & & & & 47418,4 & $<0,1$ & \\
\hline $12 / 4 / 2004$ & 24 & 28 & $11: 30$ & Não & 40 & 3,9 & 7,0 & 0,084 & 1,03 & & 29.870 & 4.570 & 23896,9 & $<0,1$ & \\
\hline $19 / 4 / 2004$ & 24 & 28 & $10: 30$ & Não & 60 & 14,2 & 6,9 & 0,125 & 1,29 & 16 & 92.080 & 11.870 & 32051,3 & 0,232 & \\
\hline $26 / 4 / 2004$ & 24,5 & 21 & $10: 35$ & fracas & 40 & 4,72 & 7,2 & 0,095 & 1,20 & 16 & $>241920$ & 1.990 & 34881 & 0,319 & \\
\hline
\end{tabular}


ANEXO 4

Dados diários de controle de precipitação 


\begin{tabular}{|c|c|c|c|c|c|c|c|}
\hline \multirow{3}{*}{$\begin{array}{l}\text { sabesp } \\
\text { P-12059 } \\
\text { Data } \\
\quad 1 / 6 / 2003\end{array}$} & \multicolumn{7}{|c|}{ COMPANHIA DE SANEAMENTO BÁSICO DO ESTADO DE SÃO PAULO - SABESP } \\
\hline & \multicolumn{7}{|c|}{$\begin{array}{c}\text { represa Guarapiranga } \\
\text { Precipitação }(\mathrm{mm})\end{array}$} \\
\hline & 0,0 & $15 / 7 / 2003$ & 0,0 & $28 / 8 / 2003$ & 1,6 & $11 / 10 / 2003$ & 21,0 \\
\hline 2/6/2003 & 0,0 & $16 / 7 / 2003$ & 0,0 & 29/8/2003 & 0,8 & $12 / 10 / 2003$ & 18,0 \\
\hline $3 / 6 / 2003$ & 0,0 & $17 / 7 / 2003$ & 0,0 & $30 / 8 / 2003$ & 0,0 & $13 / 10 / 2003$ & 3,0 \\
\hline $4 / 6 / 2003$ & 1,0 & $18 / 7 / 2003$ & 0,0 & $31 / 8 / 2003$ & 0,0 & $14 / 10 / 2003$ & 0,4 \\
\hline $5 / 6 / 2003$ & 2,6 & $19 / 7 / 2003$ & 0,0 & 1/9/2003 & 3,0 & $15 / 10 / 2003$ & 0,1 \\
\hline $6 / 6 / 2003$ & 3,1 & 20/7/2003 & 0,0 & $2 / 9 / 2003$ & 0,0 & $16 / 10 / 2003$ & 0,0 \\
\hline $7 / 6 / 2003$ & 0,0 & $21 / 7 / 2003$ & 0,0 & $3 / 9 / 2003$ & 0,0 & $17 / 10 / 2003$ & 0,0 \\
\hline $8 / 6 / 2003$ & 0,0 & $22 / 7 / 2003$ & 0,0 & 4/9/2003 & 0,0 & $18 / 10 / 2003$ & 0,0 \\
\hline 9/6/2003 & 5,4 & $23 / 7 / 2003$ & 0,0 & $5 / 9 / 2003$ & 0,0 & 19/10/2003 & 0,0 \\
\hline $10 / 6 / 2003$ & 0,0 & $24 / 7 / 2003$ & 0,0 & 6/9/2003 & 0,0 & 20/10/2003 & 0,0 \\
\hline $11 / 6 / 2003$ & 0,0 & $25 / 7 / 2003$ & 0,0 & $7 / 9 / 2003$ & 0,0 & 21/10/2003 & 1,4 \\
\hline $12 / 6 / 2003$ & 0,0 & $26 / 7 / 2003$ & 0,0 & 8/9/2003 & 0,0 & $22 / 10 / 2003$ & 1,8 \\
\hline $13 / 6 / 2003$ & 0,0 & 27/7/2003 & 0,0 & 9/9/2003 & 0,0 & 23/10/2003 & 0,4 \\
\hline $14 / 6 / 2003$ & 0,0 & $28 / 7 / 2003$ & 0,8 & $10 / 9 / 2003$ & 0,0 & $24 / 10 / 2003$ & 0,0 \\
\hline $15 / 6 / 2003$ & 0,0 & 29/7/2003 & 0,0 & $11 / 9 / 2003$ & 17,2 & $25 / 10 / 2003$ & 0,0 \\
\hline $16 / 6 / 2003$ & 0,0 & $30 / 7 / 2003$ & 0,0 & $12 / 9 / 2003$ & 0,0 & $26 / 10 / 2003$ & 0,0 \\
\hline $17 / 6 / 2003$ & 0,0 & $31 / 7 / 2003$ & 0,0 & $13 / 9 / 2003$ & 0,0 & $27 / 10 / 2003$ & 0,0 \\
\hline $18 / 6 / 2003$ & 0,0 & 1/8/2003 & 0,0 & $14 / 9 / 2003$ & 0,0 & $28 / 10 / 2003$ & 5,0 \\
\hline 19/6/2003 & 0,0 & $2 / 8 / 2003$ & 0,0 & $15 / 9 / 2003$ & 0,0 & $29 / 10 / 2003$ & 5,1 \\
\hline $20 / 6 / 2003$ & 4,2 & $3 / 8 / 2003$ & 0,0 & $16 / 9 / 2003$ & 0,2 & $30 / 10 / 2003$ & 2,0 \\
\hline $21 / 6 / 2003$ & 0,0 & $4 / 8 / 2003$ & 0,0 & $17 / 9 / 2003$ & 11,8 & $31 / 10 / 2003$ & 0,0 \\
\hline $22 / 6 / 2003$ & 0,0 & $5 / 8 / 2003$ & 0,0 & $18 / 9 / 2003$ & 0,0 & 1/11/2003 & 0,0 \\
\hline $23 / 6 / 2003$ & 0,0 & $6 / 8 / 2003$ & 0,0 & $19 / 9 / 2003$ & 0,0 & $2 / 11 / 2003$ & 0,1 \\
\hline $24 / 6 / 2003$ & 0,0 & $7 / 8 / 2003$ & 5,6 & 20/9/2003 & 0,0 & $3 / 11 / 2003$ & 2,0 \\
\hline $25 / 6 / 2003$ & 0,0 & $8 / 8 / 2003$ & 1,6 & 21/9/2003 & 0,0 & $4 / 11 / 2003$ & 2,6 \\
\hline $26 / 6 / 2003$ & 0,0 & $9 / 8 / 2003$ & 0,0 & $22 / 9 / 2003$ & 0,0 & $5 / 11 / 2003$ & 0,0 \\
\hline $27 / 6 / 2003$ & 0,0 & $10 / 8 / 2003$ & 0,0 & 23/9/2003 & 0,0 & $6 / 11 / 2003$ & 8,0 \\
\hline $28 / 6 / 2003$ & 0,0 & $11 / 8 / 2003$ & 12,4 & $24 / 9 / 2003$ & 0,0 & $7 / 11 / 2003$ & 0,1 \\
\hline $29 / 6 / 2003$ & 0,0 & $12 / 8 / 2003$ & 0,0 & $25 / 9 / 2003$ & 0,0 & $8 / 11 / 2003$ & 2,2 \\
\hline $30 / 6 / 2003$ & 0,0 & $13 / 8 / 2003$ & 0,0 & $26 / 9 / 2003$ & 0,4 & 9/11/2003 & 0,0 \\
\hline 1/7/2003 & 0,0 & $14 / 8 / 2003$ & 0,0 & $27 / 9 / 2003$ & 0,0 & 10/11/2003 & 0,0 \\
\hline 2/7/2003 & 0,0 & $15 / 8 / 2003$ & 0,0 & $28 / 9 / 2003$ & 0,0 & 11/11/2003 & 0,0 \\
\hline $3 / 7 / 2003$ & 0,0 & $16 / 8 / 2003$ & 0,0 & 29/9/2003 & 0,0 & $12 / 11 / 2003$ & 0,0 \\
\hline 4/7/2003 & 0,0 & $17 / 8 / 2003$ & 0,0 & $30 / 9 / 2003$ & 0,4 & $13 / 11 / 2003$ & 0,0 \\
\hline $5 / 7 / 2003$ & 0,0 & $18 / 8 / 2003$ & 0,0 & $1 / 10 / 2003$ & 0,0 & $14 / 11 / 2003$ & 9,6 \\
\hline $6 / 7 / 2003$ & 0,0 & 19/8/2003 & 0,0 & 2/10/2003 & 0,0 & $15 / 11 / 2003$ & 0,0 \\
\hline $7 / 7 / 2003$ & 0,0 & 20/8/2003 & 0,1 & $3 / 10 / 2003$ & 0,0 & $16 / 11 / 2003$ & 0,0 \\
\hline 8/7/2003 & 0,0 & 21/8/2003 & 0,0 & $4 / 10 / 2003$ & 0,0 & $17 / 11 / 2003$ & 11,0 \\
\hline 9/7/2003 & 0,0 & $22 / 8 / 2003$ & 0,0 & $5 / 10 / 2003$ & 0,0 & $18 / 11 / 2003$ & 6,0 \\
\hline 10/7/2003 & 1,8 & 23/8/2003 & 0,0 & $6 / 10 / 2003$ & 0,0 & $19 / 11 / 2003$ & 0,0 \\
\hline $11 / 7 / 2003$ & 11,8 & $24 / 8 / 2003$ & 0,0 & $7 / 10 / 2003$ & 0,0 & $20 / 11 / 2003$ & 0,6 \\
\hline $12 / 7 / 2003$ & 0,0 & $25 / 8 / 2003$ & 2,6 & 8/10/2003 & 2,0 & $21 / 11 / 2003$ & 2,6 \\
\hline $13 / 7 / 2003$ & 0,0 & $26 / 8 / 2003$ & 1,8 & 9/10/2003 & 0,0 & $22 / 11 / 2003$ & 0,0 \\
\hline $14 / 7 / 2003$ & 3,2 & $27 / 8 / 2003$ & 0,0 & 10/10/2003 & 9,0 & $23 / 11 / 2003$ & 0,0 \\
\hline
\end{tabular}




\begin{tabular}{|c|c|c|c|c|c|c|c|}
\hline \multirow{2}{*}{$\begin{array}{l}\text { P-12059 } \\
\text { Data } \\
\quad 24 / 11 / 2003\end{array}$} & \multicolumn{7}{|c|}{$\begin{array}{l}\text { represa Guarapiranga } \\
\text { Precipitacão }(\mathrm{mm})\end{array}$} \\
\hline & 3,8 & $7 / 1 / 2004$ & 4,0 & $20 / 2 / 2004$ & 1,0 & $4 / 4 / 2004$ & 0,0 \\
\hline $25 / 11 / 2003$ & 0,4 & $8 / 1 / 2004$ & 3,8 & $21 / 2 / 2004$ & 0,0 & $5 / 4 / 2004$ & 24,2 \\
\hline 26/11/2003 & 0,0 & $9 / 1 / 2004$ & 25,4 & $22 / 2 / 2004$ & 8,8 & $6 / 4 / 2004$ & 2,2 \\
\hline 27/11/2003 & 2,7 & $10 / 1 / 2004$ & 3,8 & $23 / 2 / 2004$ & 35,0 & $7 / 4 / 2004$ & 31,2 \\
\hline 28/11/2003 & 5,8 & $11 / 1 / 2004$ & 0,0 & $24 / 2 / 2004$ & 5,0 & $8 / 4 / 2004$ & 0,0 \\
\hline 29/11/2003 & 7,6 & $12 / 1 / 2004$ & 0,0 & $25 / 2 / 2004$ & 1,6 & $9 / 4 / 2004$ & 0,0 \\
\hline $30 / 11 / 2003$ & 0,0 & $13 / 1 / 2004$ & 1,2 & $26 / 2 / 2004$ & 2,2 & $10 / 4 / 2004$ & 0,0 \\
\hline $1 / 12 / 2003$ & 5,6 & $14 / 1 / 2004$ & 0,0 & 27/2/2004 & 0,0 & $11 / 4 / 2004$ & 9,2 \\
\hline $2 / 12 / 2003$ & 1,8 & $15 / 1 / 2004$ & 3,6 & $28 / 2 / 2004$ & 10,2 & $12 / 4 / 2004$ & 0,0 \\
\hline $3 / 12 / 2003$ & 0,0 & $16 / 1 / 2004$ & 9,4 & 29/2/2004 & 0,0 & $13 / 4 / 2004$ & 0,0 \\
\hline $4 / 12 / 2003$ & 1,2 & $17 / 1 / 2004$ & 1,2 & $1 / 3 / 2004$ & 0,0 & $14 / 4 / 2004$ & 1,0 \\
\hline $5 / 12 / 2003$ & 2,0 & $18 / 1 / 2004$ & 0,2 & $2 / 3 / 2004$ & 0,6 & $15 / 4 / 2004$ & 18,0 \\
\hline $6 / 12 / 2003$ & 32,6 & $19 / 1 / 2004$ & 0,0 & $3 / 3 / 2004$ & 0,0 & $16 / 4 / 2004$ & 18,6 \\
\hline $7 / 12 / 2003$ & 0,0 & 20/1/2004 & 0,0 & $4 / 3 / 2004$ & 12,0 & $17 / 4 / 2004$ & 0,0 \\
\hline $8 / 12 / 2003$ & 0,0 & $21 / 1 / 2004$ & 0,0 & $5 / 3 / 2004$ & 26,6 & $18 / 4 / 2004$ & 0,0 \\
\hline 9/12/2003 & 8,2 & $22 / 1 / 2004$ & 14,6 & $6 / 3 / 2004$ & 1,8 & $19 / 4 / 2004$ & 0,0 \\
\hline $10 / 12 / 2003$ & 10,6 & $23 / 1 / 2004$ & 0,2 & $7 / 3 / 2004$ & 21,0 & $20 / 4 / 2004$ & 21,0 \\
\hline $11 / 12 / 2003$ & 0,0 & $24 / 1 / 2004$ & 0,4 & $8 / 3 / 2004$ & 0,0 & $21 / 4 / 2004$ & 0,0 \\
\hline $12 / 12 / 2003$ & 0,8 & $25 / 1 / 2004$ & 2,2 & $9 / 3 / 2004$ & 1,6 & $22 / 4 / 2004$ & 4,8 \\
\hline $13 / 12 / 2003$ & 0,6 & $26 / 1 / 2004$ & 16,2 & $10 / 3 / 2004$ & 0,0 & $23 / 4 / 2004$ & 0,0 \\
\hline $14 / 12 / 2003$ & 0,0 & $27 / 1 / 2004$ & 24,0 & $11 / 3 / 2004$ & 0,0 & $24 / 4 / 2004$ & 0,0 \\
\hline $15 / 12 / 2003$ & 17,4 & $28 / 1 / 2004$ & 26,2 & $12 / 3 / 2004$ & 0,0 & $25 / 4 / 2004$ & 0,2 \\
\hline $16 / 12 / 2003$ & 0,0 & $29 / 1 / 2004$ & 2,6 & $13 / 3 / 2004$ & 0,0 & $26 / 4 / 2004$ & 1,0 \\
\hline $17 / 12 / 2003$ & 3,4 & $30 / 1 / 2004$ & 0,0 & $14 / 3 / 2004$ & 1,6 & $27 / 4 / 2004$ & 0,0 \\
\hline $18 / 12 / 2003$ & 0,2 & $31 / 1 / 2004$ & 3,0 & $15 / 3 / 2004$ & 17,8 & $28 / 4 / 2004$ & 0,0 \\
\hline $19 / 12 / 2003$ & 0,0 & $1 / 2 / 2004$ & 6,2 & $16 / 3 / 2004$ & 0,4 & $29 / 4 / 2004$ & 0,0 \\
\hline 20/12/2003 & 0,0 & $2 / 2 / 2004$ & 19,6 & $17 / 3 / 2004$ & 0,4 & $30 / 4 / 2004$ & 0,0 \\
\hline $21 / 12 / 2003$ & 0,6 & $3 / 2 / 2004$ & 36,2 & $18 / 3 / 2004$ & 0,0 & & \\
\hline $22 / 12 / 2003$ & 11,0 & $4 / 2 / 2004$ & 0,2 & $19 / 3 / 2004$ & 0,0 & & \\
\hline 23/12/2003 & 6,8 & $5 / 2 / 2004$ & 1,0 & $20 / 3 / 2004$ & 13,4 & & \\
\hline $24 / 12 / 2003$ & 3,4 & $6 / 2 / 2004$ & 7,2 & $21 / 3 / 2004$ & 0,2 & & \\
\hline $25 / 12 / 2003$ & 0,0 & $7 / 2 / 2004$ & 10,6 & $22 / 3 / 2004$ & 0,4 & & \\
\hline 26/12/2003 & 0,0 & $8 / 2 / 2004$ & 2,0 & $23 / 3 / 2004$ & 0,4 & & \\
\hline 27/12/2003 & 0,0 & 9/2/2004 & 0,8 & $24 / 3 / 2004$ & 0,4 & & \\
\hline 28/12/2003 & 0,0 & $10 / 2 / 2004$ & 0,0 & $25 / 3 / 2004$ & 0,0 & & \\
\hline 29/12/2003 & 2,4 & $11 / 2 / 2004$ & 0,4 & $26 / 3 / 2004$ & 0,0 & & \\
\hline $30 / 12 / 2003$ & 16,0 & $12 / 2 / 2004$ & 0,2 & $27 / 3 / 2004$ & 0,0 & & \\
\hline $31 / 12 / 2003$ & 0,0 & $13 / 2 / 2004$ & 1,2 & $28 / 3 / 2004$ & 0,0 & & \\
\hline $1 / 1 / 2004$ & 3,8 & $14 / 2 / 2004$ & 0,0 & $29 / 3 / 2004$ & 9,0 & & \\
\hline 2/1/2004 & 7,8 & $15 / 2 / 2004$ & 17,6 & $30 / 3 / 2004$ & 2,0 & & \\
\hline $3 / 1 / 2004$ & 0,6 & $16 / 2 / 2004$ & 1,0 & $31 / 3 / 2004$ & 0,0 & & \\
\hline $4 / 1 / 2004$ & 0,0 & $17 / 2 / 2004$ & 0,0 & $1 / 4 / 2004$ & 0,0 & & \\
\hline $5 / 1 / 2004$ & 0,0 & $18 / 2 / 2004$ & 0,0 & 2/4/2004 & 0,0 & & \\
\hline $6 / 1 / 2004$ & 0,0 & $19 / 2 / 2004$ & 0,0 & $3 / 4 / 2004$ & 0,0 & & \\
\hline
\end{tabular}


ANEXO 5

Dados diários de controle de vazões 


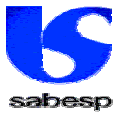

$1 / 6 / 20034,1$

$2 / 6 / 20034,0$

$3 / 6 / 20033,6$

$4 / 6 / 20032,4$

$5 / 6 / 20034,1$

$6 / 6 / 20034,3$

$7 / 6 / 20034,3$

$8 / 6 / 20034,3$

9/6/2003 4,3

$10 / 6 / 20034,1$

$11 / 6 / 20034,2$

$12 / 6 / 20034,2$

$13 / 6 / 20034,3$

$14 / 6 / 20034,2$

$15 / 6 / 20034,2$

$16 / 6 / 20034,2$

$17 / 6 / 20034,2$

$18 / 6 / 20033,0$

$19 / 6 / 20034,2$

20/6/2003 4,3

$21 / 6 / 20033,2$

$22 / 6 / 20034,1$

$23 / 6 / 20033,7$

$24 / 6 / 20034,1$

$25 / 6 / 20034,2$

$26 / 6 / 20034,2$

$27 / 6 / 20034,1$

$28 / 6 / 20034,2$

29/6/2003 4,1

$30 / 6 / 20034,2$

$1 / 7 / 20034,2$

2/7/2003 4,3

$3 / 7 / 20034,2$

$4 / 7 / 20034,2$

$5 / 7 / 20033,8$

$6 / 7 / 20033,7$

7/7/2003 3,8

$8 / 7 / 20034,2$

9/7/2003 4,2

$10 / 7 / 20034,0$

$11 / 7 / 20034,3$

$12 / 7 / 20034,3$

$13 / 7 / 20034,3$

$14 / 7 / 20033,3$

$15 / 7 / 20034,2$

$16 / 7 / 20034,3$
COMPANHIA DE SANEAMENTO BÁSICO DO ESTADO DE SÃO PAULO - SABESP

Vazões GU213 - Jaceguava

17/7/2003 4,2 3/9/2003 4,6

18/7/2003 4,1 4/9/20034,6

$19 / 7 / 20034,2$

$20 / 7 / 20034,2$

$22 / 7 / 20033,9$

$23 / 7 / 20034,2$

24/7/2003 3,8

$25 / 7 / 20034,2$

26/7/2003 4,2

$27 / 7 / 20034,2$

$28 / 7 / 20034,2$

29/7/2003 4,2

$30 / 7 / 20034,2$

$31 / 7 / 20034,2$

$1 / 8 / 20034,2$

$2 / 8 / 20034,2$

$3 / 8 / 20034,2$

$4 / 8 / 20034,2$

$5 / 8 / 20034,2$

$6 / 8 / 20034,1$

$7 / 8 / 20034,1$

$8 / 8 / 20033,9$

$9 / 8 / 20034,2$

$10 / 8 / 20034,2$

$11 / 8 / 20034,1$

$12 / 8 / 20034,2$

$13 / 8 / 20033,8$

$14 / 8 / 20034,1$

$15 / 8 / 20034,2$

$16 / 8 / 20034,1$

$17 / 8 / 20034,2$

$18 / 8 / 20034,2$

$19 / 8 / 20034,2$

20/8/2003 4,2

$21 / 8 / 20034,2$

22/8/2003 4,2

23/8/2003 4,2

24/8/2003 4,2

25/8/2003 4,1

26/8/2003 4,1

$27 / 8 / 20034,1$

28/8/2003 4,2

29/8/20034,2

$30 / 8 / 20034,2$

$31 / 8 / 20034,2$

$1 / 9 / 20034,6$

2/9/2003 4,5
20/10/2003 4,6

$21 / 10 / 20032,4$

$22 / 10 / 20034,7$

$23 / 10 / 20034,5$

$24 / 10 / 20034,6$

$25 / 10 / 20034,7$

26/10/2003 4,8

$27 / 10 / 20034,7$

28/10/2003 4,6

29/10/2003 4,6

$30 / 10 / 20034,7$

$31 / 10 / 20034,3$

$1 / 11 / 20034,7$

$2 / 11 / 20034,5$

$3 / 11 / 20034,6$

$4 / 11 / 20034,7$

$5 / 11 / 20034,8$

$6 / 11 / 20034,6$

$7 / 11 / 20034,3$

$8 / 11 / 20034,8$

9/11/2003 4,7

$10 / 11 / 20034,8$

$11 / 11 / 20034,8$

$12 / 11 / 20034,7$

$13 / 11 / 20034,6$

$14 / 11 / 20034,5$

$15 / 11 / 20034,5$

$16 / 11 / 20034,7$

$17 / 11 / 20034,4$

$18 / 11 / 20034,7$

$19 / 11 / 20034,7$ $20 / 11 / 20034,7$ $21 / 11 / 20034,8$ $22 / 11 / 20034,8$ $23 / 11 / 20034,7$ $24 / 11 / 20034,5$ $25 / 11 / 20034,8$ $26 / 11 / 20034,8$ $27 / 11 / 20034,5$ 28/11/2003 4,8 29/11/2003 4,8 $30 / 11 / 20034,7$ $1 / 12 / 20034,7$ $2 / 12 / 20034,8$ $3 / 12 / 20034,7$ $4 / 12 / 20034,7$ $5 / 12 / 20034,8$ 
COMPANHIA DE SANEAMENTO BÁSICO DO ESTADO DE SÃO PAULO - SABESP

Vazões GU213 - Jaceguava

\begin{tabular}{|c|c|c|c|c|c|c|}
\hline $6 / 12 / 2003$ & 4,8 & $15 / 1 / 2004$ & 4,9 & $24 / 2 / 2004$ & 5,0 & $4 / 4 / 2004$ \\
\hline $7 / 12 / 2003$ & 4,7 & $16 / 1 / 2004$ & 4,8 & $25 / 2 / 2004$ & 4,7 & $5 / 4 / 2004$ \\
\hline $8 / 12 / 2003$ & 4,8 & $17 / 1 / 2004$ & 4,7 & $26 / 2 / 2004$ & 4,9 & $6 / 4 / 2004$ \\
\hline 9/12/2003 & 4,7 & $18 / 1 / 2004$ & 4,8 & $27 / 2 / 2004$ & 5,0 & $7 / 4 / 2004$ \\
\hline $10 / 12 / 2003$ & 4,8 & $19 / 1 / 2004$ & 4,2 & $28 / 2 / 2004$ & 5,0 & 8/4/2004 \\
\hline $11 / 12 / 2003$ & 4,8 & 20/1/2004 & 4,7 & $29 / 2 / 2004$ & 4,9 & $9 / 4 / 2004$ \\
\hline $12 / 12 / 2003$ & 4,7 & $21 / 1 / 2004$ & 4,7 & $1 / 3 / 2004$ & 4,8 & $10 / 4 / 2004$ \\
\hline $13 / 12 / 2003$ & 4,7 & $22 / 1 / 2004$ & 4,7 & $2 / 3 / 2004$ & 4,9 & $11 / 4 / 2004$ \\
\hline $14 / 12 / 2003$ & 4,7 & 23/1/2004 & 4,8 & $3 / 3 / 2004$ & 4,8 & $12 / 4 / 2004$ \\
\hline $15 / 12 / 2003$ & 4,6 & 24/1/2004 & 4,8 & $4 / 3 / 2004$ & 5,0 & $13 / 4 / 2004$ \\
\hline $16 / 12 / 2003$ & 4,6 & $25 / 1 / 2004$ & 4,8 & $5 / 3 / 2004$ & 5,4 & $14 / 4 / 2004$ \\
\hline $17 / 12 / 2003$ & 4,7 & $26 / 1 / 2004$ & 5,5 & $6 / 3 / 2004$ & 5,1 & $15 / 4 / 2004$ \\
\hline $18 / 12 / 2003$ & 4,6 & $27 / 1 / 2004$ & 5,2 & $7 / 3 / 2004$ & 5,2 & $16 / 4 / 2004$ \\
\hline $19 / 12 / 2003$ & 4,8 & $28 / 1 / 2004$ & 5,2 & $8 / 3 / 2004$ & 5,0 & $17 / 4 / 2004$ \\
\hline $20 / 12 / 2003$ & 4,5 & 29/1/2004 & 4,9 & $9 / 3 / 2004$ & 4,9 & $18 / 4 / 2004$ \\
\hline $21 / 12 / 2003$ & 4,5 & $30 / 1 / 2004$ & 4,9 & $10 / 3 / 2004$ & 4,9 & $19 / 4 / 2004$ \\
\hline $22 / 12 / 2003$ & 4,7 & $31 / 1 / 2004$ & 5,4 & $11 / 3 / 2004$ & 4,8 & $20 / 4 / 2004$ \\
\hline $23 / 12 / 2003$ & 4,9 & $1 / 2 / 2004$ & 4,8 & $12 / 3 / 2004$ & 5,0 & $21 / 4 / 2004$ \\
\hline $24 / 12 / 2003$ & 4,8 & $2 / 2 / 2004$ & 5,1 & $13 / 3 / 2004$ & 4,8 & $22 / 4 / 2004$ \\
\hline $25 / 12 / 2003$ & 4,8 & $3 / 2 / 2004$ & 4,8 & $14 / 3 / 2004$ & 4,9 & $23 / 4 / 2004$ \\
\hline $26 / 12 / 2003$ & 4,8 & $4 / 2 / 2004$ & 4,8 & $15 / 3 / 2004$ & 4,0 & $24 / 4 / 2004$ \\
\hline 27/12/2003 & 4,8 & $5 / 2 / 2004$ & 4,7 & $16 / 3 / 2004$ & 4,4 & $25 / 4 / 2004$ \\
\hline 28/12/2003 & 4,8 & $6 / 2 / 2004$ & 4,8 & $17 / 3 / 2004$ & 5,0 & $26 / 4 / 2004$ \\
\hline 29/12/2003 & 4,8 & $7 / 2 / 2004$ & 5,0 & $18 / 3 / 2004$ & 5,0 & $27 / 4 / 2004$ \\
\hline $30 / 12 / 2003$ & 4,8 & $8 / 2 / 2004$ & 4,9 & $19 / 3 / 2004$ & 4,5 & $28 / 4 / 2004$ \\
\hline $31 / 12 / 2003$ & 4,7 & $9 / 2 / 2004$ & 4,6 & $20 / 3 / 2004$ & 5,0 & $29 / 4 / 2004$ \\
\hline $1 / 1 / 2004$ & 4,8 & $10 / 2 / 2004$ & 4,8 & $21 / 3 / 2004$ & 5,0 & $30 / 4 / 2004$ \\
\hline $2 / 1 / 2004$ & 4,9 & $11 / 2 / 2004$ & 4,6 & $22 / 3 / 2004$ & 4,9 & \\
\hline $3 / 1 / 2004$ & 4,9 & $12 / 2 / 2004$ & 4,7 & $23 / 3 / 2004$ & 5,0 & \\
\hline $4 / 1 / 2004$ & 4,4 & $13 / 2 / 2004$ & 4,7 & $24 / 3 / 2004$ & 4,8 & \\
\hline $5 / 1 / 2004$ & 4,8 & $14 / 2 / 2004$ & 4,8 & $25 / 3 / 2004$ & 5,0 & \\
\hline $6 / 1 / 2004$ & 4,8 & $15 / 2 / 2004$ & 5,1 & $26 / 3 / 2004$ & 5,1 & \\
\hline $7 / 1 / 2004$ & 4,8 & $16 / 2 / 2004$ & 4,8 & $27 / 3 / 2004$ & 5,1 & \\
\hline $8 / 1 / 2004$ & 4,8 & $17 / 2 / 2004$ & 4,7 & $28 / 3 / 2004$ & 5,0 & \\
\hline $9 / 1 / 2004$ & 4,8 & $18 / 2 / 2004$ & 4,8 & $29 / 3 / 2004$ & 4,5 & \\
\hline $10 / 1 / 2004$ & 4,5 & $19 / 2 / 2004$ & 4,6 & $30 / 3 / 2004$ & 4,5 & \\
\hline $11 / 1 / 2004$ & 4,6 & $20 / 2 / 2004$ & 4,9 & $31 / 3 / 2004$ & 4,8 & \\
\hline $12 / 1 / 2004$ & 4,8 & $21 / 2 / 2004$ & 4,8 & $1 / 4 / 2004$ & 4,9 & \\
\hline $13 / 1 / 2004$ & 4,6 & $22 / 2 / 2004$ & 5,2 & $2 / 4 / 2004$ & 4,9 & \\
\hline $14 / 1 / 2004$ & 4,5 & $23 / 2 / 2004$ & 5,5 & $3 / 4 / 2004$ & 3,9 & \\
\hline
\end{tabular}

